\title{
Potential use of cover crops for soil and water conservation, nutrient management, and climate change adaptation across the tropics
}

Jorge A. Delgado ${ }^{a, *}$, Victor H. Barrera Mosquera ${ }^{b}$, Jeffrey R. Alwang ${ }^{c}$, Alexis Villacis-Aveiga ${ }^{c}$, Yamil E. Cartagena Ayala ${ }^{b}$, Donna Neera , Carlos Monar ${ }^{\mathrm{d}}$, and Luis O. Escudero López ${ }^{\mathrm{b}}$

${ }^{a}$ USDA-ARS, Fort Collins, CO, United States

${ }^{\mathrm{b}}$ Instituto Nacional de Investigaciones Agropecurarias (INIAP), Estación Experimental Santa Catalina Panamericana Sur km 1, Quito, Ecuador

${ }^{\mathrm{c}}$ Virginia Polytechnic Institute and State University, Blacksburg, VA, United States

${ }^{\mathrm{d}}$ Universidad Estatal de Bolivar, Guaranda, Ecuador

*Corresponding author: e-mail address: jorge.delgado@usda.gov

\section{Contents}

1. Challenges for tropical regions

2. Improvement of nutrient cycling

2.1 Temperate regions

2.2 Tropical regions

3. Improvement of yields

3.1 Temperate regions

3.2 Tropical regions

4. Not a silver bullet

5. Reduction of erosion and offsite transport of nutrients 198

6. Contribution to soil quality/soil health and sustainability 201

7. Conservation of water quality 204

8. Management and challenges 207

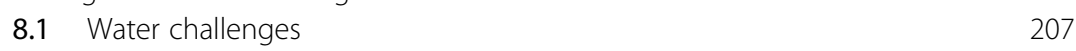

8.2 Weeds and nematode management 209

$\begin{array}{ll}8.3 & \text { Salinity and grazing challenges } \\ 8.4 & 209\end{array}$

8.4 Social challenges to adoption 209

9. Carbon sequestration 212

10. Case scenario from the Ecuadorian Andes 213

10.1 New cover crops, residue management and no-till system 213

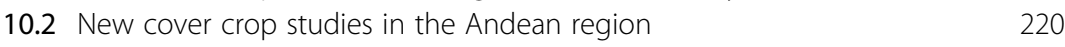

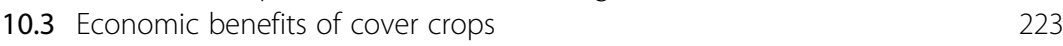


$\begin{array}{ll}10.4 & \text { Opportunity costs } \\ & 223\end{array}$

10.5 Policy implications 223

11. Cover crops for climate change adaptation 225

11.1 Potential of cover crop impacts to contribute to climate change adaptation 225

12. Research gaps 228

$\begin{array}{ll}12.1 \text { List of research gaps } & 229\end{array}$

13. Summary 231

Glossary $\quad 236$

$\begin{array}{ll}\text { References } & 237\end{array}$

\section{Abstract}

One of the greatest challenges in the 21st century is the question of how humanity will adapt to a changing climate to continue producing food at the production levels that will be necessary to feed an increasing global population while conserving soil and water resources. While there are political, social and economic factors that impact agricultural development, this paper will not be focusing on those factors, instead focusing on the potential use of cover crops as a nutrient management tool, a soil and water conservation practice, and a good approach to adapting to a changing climate. The potential of using cover crops for climate change adaptation and mitigation will be reviewed. Cover crops are a key tool that could contribute to increased yields, conservation of surface and groundwater quality, reduced erosion potential, sequestration of atmospheric carbon (C), and improved soil quality and health across the tropics. However, there are a lot of research gaps, and there is a need for additional research about the potential use of cover crops for soil, human, and animal health, as well as a need for an open-access data information system about research on cover crops in the tropics. While cover crops show a lot of promise, they are not a silver bullet, and in some circumstances, they can also contribute to reduced yields. We evaluated the use of cover crops and we ranked the different ways that cover crops can contribute to climate change adaptation, on a scale ranging from very low potential to contribute to climate change adaptation to very high potential. For example, cover crops have very high potential to reduce erosion generated by a changing climate in humid systems. On average, cover crops appear to be a good practice for climate change adaptation and mitigation across the tropics, and nutrient managers, agronomists, and soil and water conservation practitioners could add them to their management toolbox for different regions of the tropics. The 4 Rs of cover crops should be applied when using this tool (the right cover crop, the right timing of placement, the right timing of killing, and the right management).

\section{Challenges for tropical regions}

One of the most serious challenges of the 21st century is the threat of a changing climate, and the tropics are already being affected. With an ever-growing population in these regions, reflective of global trends 
suggesting the total world population will reach 9.5 billion by 2050 , food security will be a great challenge. The tropics comprise around 36\% of the Earth's landmass and about a third of the global human population (https://www.nationalgeographic.org/encyclopedia/tropics/), but they are expected to comprise $50 \%$ of the world population by 2050 (two-thirds of its children), suggesting that there is an urgent need to use cover crop practices for soil and water conservation and increased productivity, to achieve food security in the decades to come (State of the Tropics, 2017). Tropical regions are no exception to this need, especially if these regions are impacted significantly by higher temperatures and extreme weather events (e.g., longer droughts), which would impact agricultural productivity across these regions (Corlett, 2014; Lobell et al., 2011; Trewin, 2014; WMO, 2019).

Recent studies have reported that climate change is already impacting the tropics and generating high-risk environments that are exacerbating food insecurity, impacting human and animal health in many parts of the tropics, particularly in tropical regions of Africa that are being hit with extensive droughts, which increase the overall risk of climate-related illness and deaths (Ray et al., 2019; WMO, 2019). In order to have a better opportunity to adapt to the great challenges presented by our changing climate, we will need to understand their potential impacts on cropping systems and yields (Corlett, 2014; Delgado et al., 2011; Lobell et al., 2011; Ray et al., 2019; Trewin, 2014; Walthall et al., 2012; WMO, 2019). Modeling simulations suggest that there are regions where the yields will be significantly negatively impacted, while other regions, such as high-altitude tropical regions, may benefit from higher temperatures (Corlett, 2014; Lobell et al., 2011; Trewin, 2014). The bottom line is that changes in temperatures will not be the only factor to impact yields; changing climate may affect water availability (e.g., droughts, snowpack, evapotranspiration, etc.) and have potential impacts on soil erosion as well, which would also impact yields (Corlett, 2014; Delgado et al., 2013; SWCS, 2003, 2007; Trewin, 2014). Fortunately, there is potential to use conservation practices to adapt to climatic changes (Delgado et al., 2011; Walthall et al., 2012). However, in extreme weather events where there is complete crop failure, we may not be able to adapt, and other decisions will be have to be made (Lal et al., 2012; Scheelbeek et al., 2018; Tigchelaar et al., 2018). In general, there is widespread agreement that changing climate across the tropics will have a negative impact via droughts, extreme weather events, and impacts on water and snowpack (Corlett, 2014; Scheelbeek et al., 2018; Tigchelaar et al., 2018; Trewin, 2014). 
Impacts from a changing climate will be variable in space and time; for example, it has been reported that tropical highlands may benefit from higher temperatures (Corlett, 2014). On the other hand, model simulations show that the climatic changes that are occurring now are happening more rapidly and abruptly than ever before in our planet's history, so species in the tropics may not be able to adapt to these changes effectively (Corlett, 2014). With conservation agriculture we may be able to increase economic returns, increase yields, reduce the potential for erosion, and potentially adapt to a changing climate and more frequent extreme events that may lead to increased erosion. Recent studies on conservation agriculture (no-till, crop residue management, and cover crops, with nitrogen $[\mathrm{N}]$ fertilizer) have shown that cover crops can contribute to increased yields and economic returns in tropical highlands in an Andean region (Barrera et al., 2019; Delgado et al., 2019).

The ever-growing global population is up against serious challenges presented by a changing climate and extreme weather events that threaten soil quality and productivity across tropical regions. A statement by the United Nations (UN) Secretary General about a recent special report on climate change acknowledged the severity of this challenge, noting that climate change is occurring at a faster rate than humanity is addressing it and that it is already impacting humanity (United Nations, 2018). Some of the challenges that come with the growth of the human population are complex. For example, as developing countries around the world increase in wealth, demand increases for protein, a resource-intensive macronutrient. Another challenge related to the need to increase agricultural production is the overexploitation of groundwater resources for irrigation water to increase yields (Hu et al., 2005; Marston et al., 2015).

Climate change is also impacting snowpack in some areas, with decreased snowfall in some regions and other regions experiencing higher temperatures, speeding up snow melt and increasing early runoff; these effects are also contributing to reduced water availability during the growing season in some regions (Corlett, 2014; Trewin, 2014; WMO, 2019). These impacts from climate change are important, and are particularly troubling in light of research findings that irrigated systems, on average, produce twice the yields of non-irrigated systems (Bucks et al., 1990; Rangely, 1987; Tribe, 1994). Other management problems related to a changing climate are impacts from zoonotic and vector-borne diseases due to changes in extreme weather events such as droughts, floods, and hurricanes, which also impact food security (Watts et al., 2015). 
There is potential to use soil and water conservation practices to develop best management practices that will contribute to efforts to adapt to a changing climate (Delgado et al., 2011; Walthall et al., 2012). Some professional societies that work in the area of soil and water conservation have adopted position statements that state that using best conservation/management practices will be key to adapting to a changing climate (https://www. swcs.org/resources/publications/position-statement-climate-change;http:// www.waswac.org/waswac/LatestNews/webinfo/2017/06/149639162269 3300.htmhttps://www.swcs.org/resources/publications/position-statementclimate-change Delgado and Li, 2016; Delgado et al., 2011). Among the key principles that have been developed for climate change adaptation is the use of cover crops to reduce surface transport and erosion potential, increase nutrient cycling, reduce losses of nutrients off site, increase C sequestration, improve soil water retention, and achieve other potential benefits (Delgado and Li, 2016; Delgado et al., 2011).

Only countries that implement conservation practices for climate change adaptation will have a chance to adapt to this threat of a changing climate and conserve their soil and water quality (Delgado et al., 2011, Fig. 1). All the data strongly suggest that without conservation practices the survival of the human species will be in jeopardy in the 21 st century and that policies and programs to implement conservation practices for climate change adaptation everywhere will be critical to help maintain the productivity levels needed for food security (Figs. 2 and 3, Delgado et al., 2011, 2013; Spiegal et al., 2018; Walthall et al., 2012). Bakker et al. (2004) reported that depending on the methodology used, the variability in loss of soil productivity will range from $4.3 \%$ to $29.6 \%$ per every $10 \mathrm{~cm}$ of soil that is lost due to erosion. This is deeply concerning since each subsequent loss of $10 \mathrm{~cm}$ of soil will result in a much greater loss in soil productivity than the previous $10 \mathrm{~cm}$, due to the fact that the most productive soils typically reside at the soil surface and as the surface soil is lost, the less productive subsoil is exposed. Pruski and Nearing (2002) reported that changes in rainfall patterns due to climate change will impact erosion rates, and that the rate of erosion will increase by $1.7 \%$ per every $1 \%$ increase in total rainfall, assuming a temporally stationary relationship between the amount and intensity changes. Additionally, the increased occurrence of extreme weather events that is also expected to accompany climatic changes will increase the potential to erode the most productive soil, and in tropical regions precipitation events carry a lot of energy, which is projected to increase. 


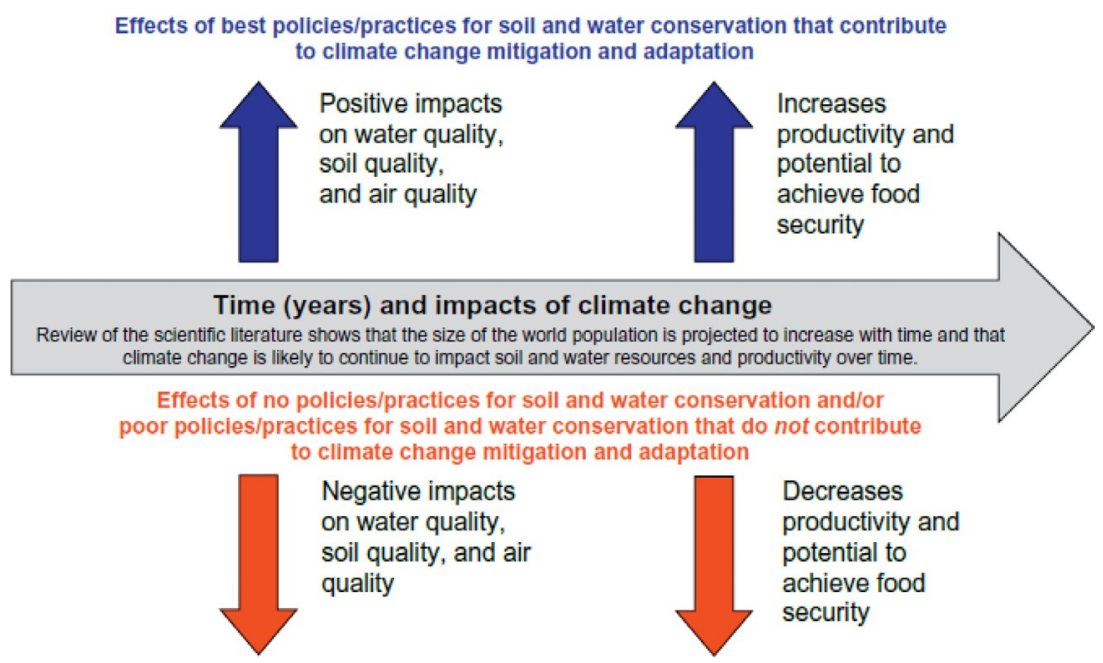

Fig. 1 There is a close relationship between climate change, limited global water and soil resources, population growth and food security. As climate change impacts the world's soil and water resources, it threatens to negatively impact food production (i.e., decrease food production and/or food production potential). As the climate changes, conservation practices have the potential to help us achieve maximum sustainable levels of food production, which will be essential to efforts to feed the world's growing population. Good policies/practices for soil and water conservation will contribute to positive impacts on soil and water quality, soil productivity, and efforts toward achieving and/or maintaining food security. These good policies/practices will contribute to climate change mitigation and adaptation. Poor policies/practices for soil and water conservation (or a lack of policies/practices) will contribute to negative impacts on soil and water quality, soil productivity, and efforts toward achieving and/or maintaining food security. From Delgado, J. A., Groffman, P. M., Nearing, M. A., Goddard, T., Reicosky, D., Lal, R., Kitchen, N. R., Rice, C. W., Towery, D., and Salon, P., 2011. Conservation practices to mitigate and adapt to climate change. J. Soil Water Conserv. 66, 118A-129A. doi:10.2489/jswc.66.4.118A.

We propose that cover crops will be an important tool for climate change adaptation and mitigation across the tropics. Several authors have reviewed the literature on cover crops in temperate regions and how cover crops can be used as management tools, with objectives ranging from conserving soil and water quality, to improving nutrient management (Clark, 2007; Crews and Peoples, 2005; Dabney et al., 2001, 2010; Grant et al., 2002; Meisinger et al., 1991; Reeder and Westermann, 2006; Reeves, 1994; Russelle and Hargrove, 1989; Snapp et al., 2005; Thorup-Kristensen, 2001; Thorup-Kristensen et al., 2003). There are also publications that review the literature on cover crops in tropical regions (Buckles, 1995; Chibarabada et al., 2017; Chikowo et al., 2010; Ganry et al., 2001). 


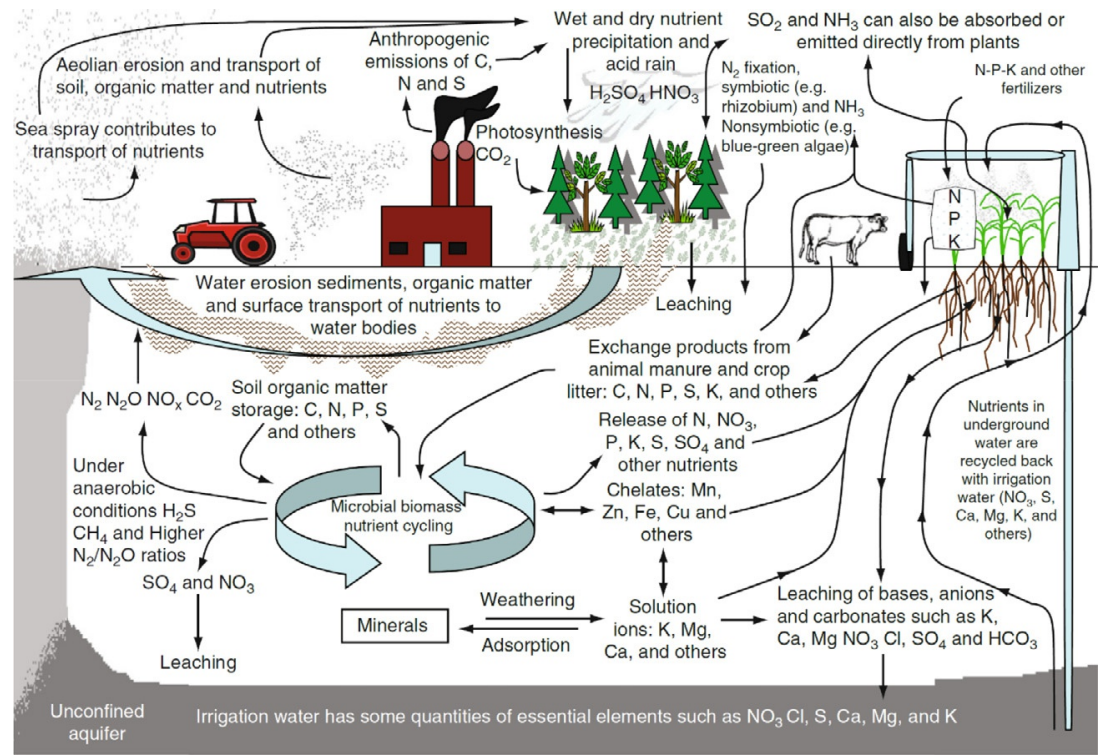

Fig. 2 Nutrient cycles of essential elements for crop production, showing their fate and transport in the environment. From Delgado, J. A., and Follett, R. F., 2002. Carbon and nutrient cycles. J. Soil Water Conserv. 57, 455-464.

Effects of organic carbon on nutrient cycling and productivity
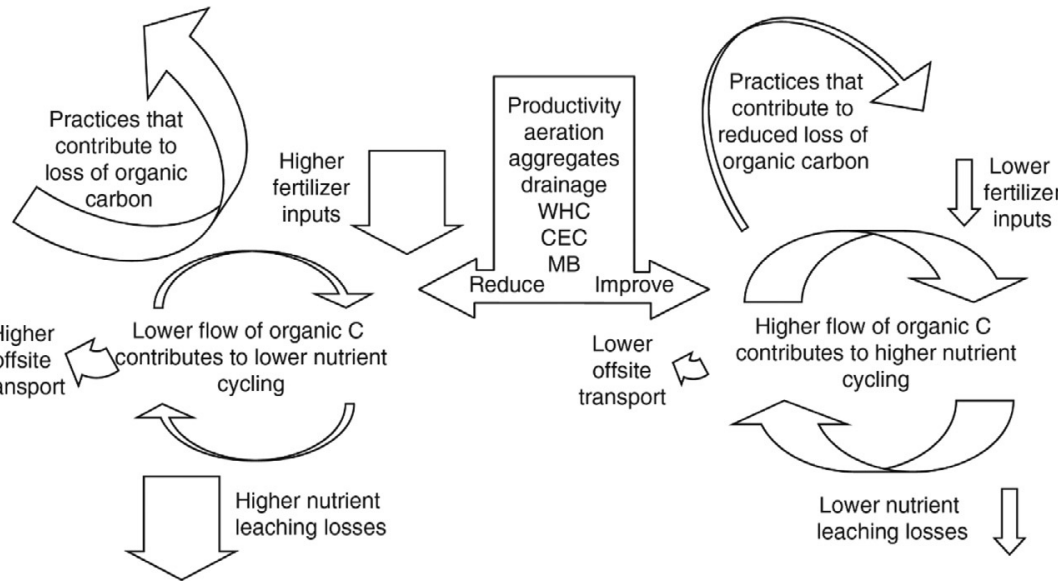

Higher flow of organic $\mathrm{C}$ contributes to higher nutrient cycling

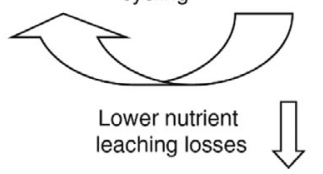

Fig. 3 Potential organic C contribution to nitrogen cycling (+ organic $\mathrm{C}_{i}+\mathrm{N}$ cycling; $\mathrm{N}$ fertilizer); use efficiency (+ organic $\mathrm{C} ;+\mathrm{N}$ use efficiency); nitrogen leaching (+ organic $\mathrm{C} ;-\mathrm{N}$ leaching); and nitrogen losses, under best management practices. From Delgado, J. A., and Follett, R. F., 2002. Carbon and nutrient cycles. J. Soil Water Conserv. 57, 455-464. 


\section{Improvement of nutrient cycling}

\subsection{Temperate regions}

There is great potential for cover crops to cycle significant amounts of $\mathrm{N}$ to the subsequent crop, with a higher $\mathrm{N}$ fertilizer equivalent, when we use aboveground crop residues that have lower $\mathrm{C}$ to $\mathrm{N}$ ratios of 20 (Doran and Smith, 1991). Doran and Smith (1991) assigned higher N fertilizer equivalents to cover crops with $\mathrm{C}$ to $\mathrm{N}$ ratios lower than 20 , which are capable of cycling more $\mathrm{N}$ from their crop residue (e.g., leguminous crops) to the subsequent crop. The opposite has been reported for crop residues that have $\mathrm{C}$ to $\mathrm{N}$ ratios higher than 35 , which will have a significantly lower $\mathrm{N}$ fertilizer equivalent and will cycle low quantities of $\mathrm{N}$ to the subsequent crop or even immobilize available N (Pink et al., 1945, 1948). Examples of studies with cover crops with low $\mathrm{C}$ to $\mathrm{N}$ ratios that significantly contributed to the $\mathrm{N}$ uptake by the subsequent crop include studies conducted by Evanylo (1991), Shipley et al. (1992), and Wagger (1989). More specifically, several authors have reported on how species, growth stage, management, climate, and lignin, carbohydrate, and cellulose contents affect $\mathrm{N}$ cycling (Bowen et al., 1993; Delgado et al., 2010a; Quemada and Cabrera, 1995a,b).

Delgado and Follett (2002) reported that by increasing soil organic matter (SOM), $\mathrm{N}$ losses could be significantly reduced and nutrient managers could account for the higher amount of $\mathrm{N}$ sequestered in the SOM and the higher $\mathrm{N}$ cycling potential, reducing $\mathrm{N}$ inputs. To improve $\mathrm{N}$ management, it is important that $\mathrm{C}$ sequestration-management also be considered in order to account for $\mathrm{N}$ cycling and reduce $\mathrm{N}$ inputs while contributing to reduced $\mathrm{N}$ losses with adequate accounting of $\mathrm{N}$ cycling (Delgado and Follett, 2002). One of the tools that can be used to sequester $\mathrm{N}$ in the organic matter is cover crops, which can increase the $\mathrm{N}$ sequestration potential and thus increase the cycling of $\mathrm{N}$ (Alsheikh et al., 2005). We can improve $\mathrm{N}$ management with cover crops. Leguminous cover crops have the potential to cycle more $\mathrm{N}$ to the next cover crop than non-leguminous cover crops (Clark et al., 1997a,b, 2007a,b).

Delgado et al. (2010a) reported that in studies conducted in temperate regions, the crop's average recovery of the applied inorganic $\mathrm{N}$ fertilizer in the aboveground compartment was about $43 \%$, which was about three times higher than the recovery of the $\mathrm{N}$ in the aboveground crop residue 
of cover crops, which was about $14 \%$. Thus, inorganic $\mathrm{N}$ fertilizer is more readily available and easily taken up by the crop than the $\mathrm{N}$ cycling from the added crop residue (Delgado et al., 2010a). With that said, if we look at the system efficiency as far as the recovery of the $\mathrm{N}$ in the crop and soil and how much $\mathrm{N}$ is lost from the system, it is the opposite, and the readily available inorganic $\mathrm{N}$ fertilizer has a lower efficiency and higher $\mathrm{N}$ losses from the cropping systems than the $\mathrm{N}$ from crop residues (Delgado et al., 2010a).

When considering the losses from the crop-soil system, the system efficiency of the $\mathrm{N}$ in the aboveground residues of cover crops is significantly higher than the system efficiency of inorganic $\mathrm{N}$ fertilizer (Delgado et al., 2010a). The reported $\mathrm{N}$ losses of inorganic fertilizer from the crop and soil system $(31 \%)$ were about three times higher than the $\mathrm{N}$ losses from crop residues (13\%). These studies conducted in temperate systems in Colorado and Washington show that the $\mathrm{N}$ cycling from crop residues to the subsequent crops will depend on the crop residue and will be impacted significantly by the $\mathrm{C}$ to $\mathrm{N}$ ratio (Delgado et al., 2010a).

The $\mathrm{N}$ losses due to nitrate leaching from inorganic $\mathrm{N}$ fertilizer are significantly higher than the $\mathrm{N}$ leaching from cover crop residue (Delgado et al., 2010a). By retaining the $\mathrm{N}$ in the crop residue, the indirect emissions of $\mathrm{N}_{2} \mathrm{O}$, as previously reported by the IPCC methodology, were lower (Delgado et al., 2010a). Based on these results, Delgado et al. (2010a) recommended that the IPCC modify its methodologies since the crop coefficients for $\mathrm{N}_{2} \mathrm{O}$ emissions due to direct and indirect $\mathrm{N}_{2} \mathrm{O}$ emissions needed to be reduced. The IPCC has recently incorporated significant changes to account for lower losses of $\mathrm{N}_{2} \mathrm{O}$ emissions from crop residues.

Using crop residue exchange plots in Colorado, Delgado et al. (2004) reported that from the wheat (Triticum aestivum L.) residue, with an aboveground $\mathrm{N}$ content of $39 \mathrm{kgNha}^{-1}$, the cycling to the subsequent potato (Solanum tuberosum L.) crop was about 6-7\%. Using the same experimental design, Collins et al. (2007) found that the $\mathrm{N}$ cycling from a mustard residue with an aboveground $\mathrm{N}$ content of $142 \mathrm{~kg} \mathrm{Nha}^{-1}$, to the potato was $29 \%$. If we assume $\mathrm{N}$ use efficiencies (NUE) of $50 \%$, the total inorganic $\mathrm{N}$ fertilizer equivalent of the $\mathrm{N}$ from the crop residue that was cycled to the subsequent potato crop will be close to $60 \mathrm{~kg} \mathrm{Nha}^{-1}$ in the case of the mustard residue, which is a significant amount of $\mathrm{N}$ fertilizer equivalent.

Macro- and micro-nutrient cycling from cover crops to the subsequent crop can be significant in temperate regions (Delgado et al., 2007b, 2010a). Delgado et al. (2007a) reported that the cover crop sorghum sudangrass (Sorghum bicolor S. sudanense) increased the macro- and micro-nutrient 
uptake in Colorado. Delgado et al. (2007a,b) estimated that about 4\%, 19\% and $4 \%$ of the copper, manganese, and zinc respectively in the cover crop were absorbed by the subsequent potato crop.

\subsection{Tropical regions}

\subsubsection{Nitrogen}

Similarly to temperate regions, in tropical systems we could use leguminous cover crops to add nutrients (especially $\mathrm{N}$ ), cycling atmospheric $\mathrm{N}$ to the subsequent crop, which could have significant impacts in low-input tropical systems and simultaneously add important organic matter that can contribute to adaptation to a changing climate (Kambauwa et al., 2015). Perin et al. (2006) reported that residue decomposition of leguminous cover crops in the tropics is quickly releasing $\mathrm{N}$ to the environment. Seo et al. (2006) in Korea found similar results to those from Delgado et al. (2004) and Collins et al. (2007) as far as assessing the uptake of the ${ }^{15} \mathrm{~N}$ by the crop being higher from the fertilizer (32\%) than the total uptake from the hairy vetch (Vicia villosa Roth) crop residue (15\%).

Perin et al. (2006) studied the release of $\mathrm{N}$ from the leguminous cover crop sunn hemp (Crotalaria juncea) and non-leguminous cover crop millet (Pennisetum glaucum) without addition of $\mathrm{N}$ fertilizer, and the effects on corn (Zea mays L.) $\mathrm{N}$ uptake and yields in Vicosa, Brazil, north of Rio de Janeiro. They also had a cover crop treatment of a mixture of sunn hemp and millet. They found that if the leguminous cover crop is mixed with a non-leguminous cover crop, the $\mathrm{N}$ release could be slower. Additionally, they also studied how these two cover crop treatments affected the yield of the corn when $90 \mathrm{kgNha}^{-1}$ of $\mathrm{N}$ fertilizer was applied to corn. Perin et al. (2006) used the natural ${ }^{15} \mathrm{~N}$ abundance technique to assess the biological $\mathrm{N}$ fixation (BNF). Using this ${ }^{15} \mathrm{~N}$ technique they calculated that $174 \mathrm{kgNha}^{-1}$ was biologically fixed in the aboveground sunn hemp compartment, which was higher than the $89 \mathrm{kgNha}^{-1}$ atmospheric $\mathrm{N}$ in the mixed cover crop. The total $\mathrm{N}$ uptake with sunn hemp of $305 \mathrm{kgNha}^{-1}$ from atmospheric and soil $\mathrm{N}$ sources was higher than the total $\mathrm{N}$ uptake with the sunn hemp and millet cover crop mixture of $218 \mathrm{kgNha}^{-1}$, and both of them had higher total $\mathrm{N}$ uptake than the millet aboveground $\mathrm{N}$ content $\left(97 \mathrm{kgNha}^{-1}\right)$.

Perin et al. (2006) measured decay rates of 15 and 22 days to release half of the $\mathrm{N}$ that was taken up from sunn hemp and sunn hemp + millet residues, respectively. Interestingly, Perin et al. (2006) found that the corn grain yields of $8.4 \mathrm{Mgha}^{-1}$ when no $\mathrm{N}$ was applied following cover crop mixture plots 
(which had slower release of $\mathrm{N}$ from the crop residue) tended to be higher than the corn grain yields of $6.6 \mathrm{Mgha}^{-1}$ measured with the sunn hemp plot, which released $\mathrm{N}$ faster. The corn yields of the non-fertilized sunn hemp and cover crop mixture plots were not significantly different. However, the corn grain yields from the sunn hemp were also not different from the corn grain yields of $4.3 \mathrm{Mgha}^{-1}$ in the millet cover crop plots. The corn grain yields from the cover crop mixture plots were significantly higher than the corn grain yields in the millet cover crop plots.

Perin et al. (2006) found that the corn's total aboveground $\mathrm{N}$ uptake of $285 \mathrm{kgNha}^{-1}$ when no fertilizer $\mathrm{N}$ was applied in the mixed cover crop plots was higher than the total aboveground $\mathrm{N}$ uptake of $173 \mathrm{kgNha}^{-1}$ in the sunn hemp. The corn's total aboveground $\mathrm{N}$ in the millet cover crop plots was $137 \mathrm{kgN} \mathrm{ha}^{-1}$. The responses in yields and aboveground $\mathrm{N}$ uptake with the zero $\mathrm{N}$ fertilizer treatments suggest that there is a significant, rapid release of $\mathrm{N}$ from the sunn hemp cover crop that is being lost to the environment.

Perin et al. (2006) used the ${ }^{15} \mathrm{~N}$ natural abundance technique to assess background ${ }^{15} \mathrm{~N}$ to measure the uptake of $\mathrm{N}$ in the corn that came from atmospheric $\mathrm{N}$ fixation and they reported that the ${ }^{15} \mathrm{~N}$ budgets assessed that $15 \%$ and $10 \%$ of corn grain $N$ was recovered from BNF from the sunn hemp and mixed cover crop, respectively. Using this ${ }^{15} \mathrm{~N}$ technique they calculated that 25.2 and $21.3 \mathrm{~kg} \mathrm{Nha}^{-1}$ came from the atmosphere for the sunn hemp and mixed cover crop, respectively.

The corn's total aboveground $\mathrm{N}$ uptake for the fertilizer corn plots following the sunn hemp, the mixed, and the millet cover crops was 318, 298 , and $197 \mathrm{kgNha}^{-1}$, respectively. We used these numbers from Perin et al. (2006) to calculate the total NUE by subtracting the total $\mathrm{N}$ uptake for each treatment of the non-fertilized corn plots from the total aboveground $\mathrm{N}$ uptake of the fertilized plots, and then dividing by the rate of $\mathrm{N}$-fertilizer applied. We calculated a fertilizer NUE of 161\%, 14\% and $67 \%$ for the sunn hemp, the mixed, and the millet cover crops, respectively.

The Perin et al. (2006) mineralization data showed rapid decomposition and release; however, when we look at the recoveries using the ${ }^{15} \mathrm{~N}$ and the NUE definition as described above that accounts for $\mathrm{N}$ uptake from nonfertilized plots, the efficiencies of the $\mathrm{N}$ in the cover crop residue that was added with the sunn hemp were significantly higher, so these methodologies are not in sync. Additionally, with $\mathrm{N}$ fertilizer the grain yields of corn were 10.8 and $10.3 \mathrm{Mgha}^{-1}$ for the sunn hemp and mixed cover crop respectively, which were higher than the $6.1 \mathrm{Mgha}^{-1}$ with the millet cover 
crop. The data suggest that adding $90 \mathrm{kgNha}^{-1}$ to the cover crop sunn hemp is the most effective way to increase efficiency of $\mathrm{N}$ fertilizer and the efficiency of the total recovery of $\mathrm{N}$ in the cover crop, either from soil or atmospheric $\mathrm{N}$, followed by the millet crop which has a higher efficiency of the $\mathrm{N}$ fertilizer but a smaller yield. Although a mixed cover crop of sunn hemp and millet has a lower NUE than the millet alone, it also increases the yields to a greater extent than the millet cover crop alone. These studies show that there are significant benefits to adding $\mathrm{N}$ fertilizer to increase the grain yields, and that since $90 \mathrm{kgNha}^{-1}$ is not enough to maximize corn grain yields, by using a leguminous cover crop, the yields are maximized and the efficiencies of both atmospheric and fertilizer sources are increased.

Lehmann et al. (2000) studied the effects of leguminous cover crops as a source of $\mathrm{N}$ for an agroforestry system in central Amazonian Brazil. They also used the natural ${ }^{15} \mathrm{~N}$ abundance technique to assess the contribution of a leguminous cover crop, Pueraria phaseoloides Roxb. (Benth.) (tropical kudzu) and to assess the $\mathrm{N}$ cycling from the cover crop to two indigenous fruit tree species, Theobroma grandiflorum Willd. (ex Spreng.) K. Schum. (cupuaçu) and Bactris gasipaes Kunth (peachpalm) for heart of palm production. Lehmann et al. (2000) reported that the cover crop tropical kudzu was important in the $\mathrm{N}$ cycling as far as serving as a scavenger crop because it could recover $31 \%$ of the fertilizer, which was a higher recovery than that by cupuaçu (20\%) and peachpalm (21\%). However, the natural ${ }^{15} \mathrm{~N}$ abundance technique did not show that a significant amount of $\mathrm{N}$ from the cover crop is cycled to the trees. They suggested that the minimal transfer of $\mathrm{N}$ to the trees is because the cupuaçu and peachpalm fruit trees have low lateral root activity and most of the $\mathrm{N}$ comes from applied fertilizer around these trees.

Tirado-Corbalá et al. (2018) measured different rates of decomposition of two legume cover crops, lablab (Lablab purpureus cv. "Rongai") and Velvet bean (Mucuna pruriens), in the wet and dry seasons of an Oxisol soil in Puerto Rico. They found that both cover crops help supply inorganic N, but that $\mathrm{N}$ mineralization from Rongai was faster than Velvet bean. They concluded that Rongai would be a better choice as a $\mathrm{N}$ source for fastgrowing row or vegetable crops in Puerto Rico.

\subsubsection{Nutrients}

Using 1-mm mesh nylon bags, Luna-Orea et al. (1996) studied the rate of decomposition and nutrient cycling for two leguminous tropical cover crops, Desmodium adscendens (Sw.) DCo (syn. Ovalifolium Guillemin \& 
Perrottet) and tropical kudzu in two sites in Bolivia. They grew the cover crops for 12 and 18 months. The younger, 1-year-old cover crop decomposed faster, having just 24\% remaining for Desmodium and 16\% for tropical kudzu in dry matter content after 30 weeks, which was lower than the $53 \%$ for Desmodium and $32 \%$ for tropical kudzu in dry matter content when it was grown for $1 \frac{1}{2}$ years. Similarly, growing these leguminous cover crops for just 12 months before incorporating them released the nutrients much faster than if they would have been grown for 18 months. The average $\mathrm{N}, \mathrm{P}, \mathrm{K}, \mathrm{Ca}$ and $\mathrm{Mg}$ content of the leguminous crop residue averaged $32 \%, 13 \%, 3 \%, 28 \%$ and $26 \%$, respectively at one of the sites. These results show that leguminous cover crops can be managed to provide nutrients relatively quickly that will potentially cycle into the next crop.

Cover crops contribute to increased cycling of macro- and micronutrients in the tropics. The cover crop Palisadegrass [Urochloa brizantha (Hochst. Ex A. Rich.) R.D. Webster] [syn. Brachiaria brizantha (Hochst. Ex A. Rich) Stapf] grown in tropical areas of Brazil contributed to higher SOM content and a lower $\mathrm{pH}$. Similarly, N, P, K, Ca, and S increased in both soybean (Glycine max (L.) Merr) and white oat (Avena sativa L.) leaves following the cover crop in 2 years when the crops were harvested (Crusciol et al., 2015). Increases in $\mathrm{Mg}$ in the soybean leaves were also observed in two of the soybean crops that were harvested and for one of the white oats crops that were harvested after the Palisadegrass cover crop.

Nutrient concentrations of $\mathrm{N}, \mathrm{P}, \mathrm{K}, \mathrm{Ca}, \mathrm{Mg}$ and $\mathrm{S}$ were also higher for corn following the cover crop. These results suggest that the inclusion of the palisadegrass cover crop in these cropping systems will contribute not only to higher yields, but will also contribute to a higher quality of grain with great nutritional value, which could potentially also have positive effects on human and animal health. Crusciol et al. (2015) found that the concentrations of $\mathrm{K}, \mathrm{Ca}, \mathrm{Mg}$, and $\mathrm{S}$ also increased across the soil surface $(0-40 \mathrm{~cm})$ with the palisadegrass cover crop. The data suggested that the crop residue and increase in SOM may have contributed to increases in $\mathrm{N}$ and $\mathrm{P}$ in the subsequent crops even if a significant increase in the soil was not detected.

Chikowo et al. (2010) conducted a review of literature about how management practices affect $\mathrm{N}$ and phosphorus $(\mathrm{P})$ capture and recovery efficiencies in sub-Saharan Africa. One of the best management practices reviewed was the use of improved fallows, cover crops and cereal sequences. Chikowo et al. (2010) reported that the total $\mathrm{N}$ availability from $86 \mathrm{~N}$ and $\mathrm{P}$ fertilizer studies for sub-Saharan Africa ranged from 13 to $191 \mathrm{~kg} \mathrm{Nha}^{-1}$, with a mean of $94 \mathrm{kgNha}^{-1}$ (standard deviation of 49), which was lower 
than the $\mathrm{N}$ availability in 64 improved fallow/cover crops studies, where it ranged from 13 to $400 \mathrm{kgNha}^{-1}$ with a mean of $146 \mathrm{kgNha}^{-1}$ (standard deviation of 86).

Chikowo et al. (2010) reported that the $\mathrm{N}$ uptake from $85 \mathrm{~N}$ and $\mathrm{P}$ fertilizer studies for this region ranged from 6 to $136 \mathrm{kgNha}^{-1}$ with a mean of $53 \mathrm{kgNha}^{-1}$ (standard deviation of 32), which was similar to the $\mathrm{N}$ uptake from 68 improved fallow/cover crop studies, which ranged from 8 to $149 \mathrm{kgNha}^{-1}$ with a mean of $48 \mathrm{kgNha}^{-1}$ (standard deviation of 29). However, Chikowo et al. (2010) found a low correlation between $\mathrm{N}$ availability from cover crops and $\mathrm{N}$ uptake $\left(\mathrm{r}^{2}=0.16\right)$, while the correlation between the $\mathrm{N}$ fertilizer and $\mathrm{N}$ uptake was higher $\left(\mathrm{r}^{2}=0.61\right)$. The maximum projected $\mathrm{N}$ uptake with the regression line is around $60 \mathrm{~kg} \mathrm{Nha}^{-1}$ with the cover crops, which was much lower (about 60\%) than the maximum projected $\mathrm{N}$ uptake with the regression line with the $\mathrm{N}$ fertilizer of about $100 \mathrm{kgNha}^{-1}$. These results from sub-Saharan Africa are in agreement with findings in Brazil that the fertilizer $\mathrm{N}$ increases the uptake of $\mathrm{N}$.

\section{Improvement of yields}

\subsection{Temperate regions}

Across temperate regions cover crop mixtures such as a legume as an intercrop with switchgrass (Panicum virgatum L.) can contribute to increased forage quality and yields, contributing to reduced need for fertilizer and potentially lower nitrate leaching potential (Ashworth et al., 2015). Crop quality and yields can be increased with cover crops (Delgado et al., 2007a; Essah et al., 2012). Positive impacts on yields have also been reported by other scientists (Clark, 2007; Dabney et al., 2001, 2010; Delgado et al., 2007a; Essah et al., 2012; Marcillo and Miguez, 2017; Thorup-Kristensen et al., 2003). Reviews of literature on the impacts of cover crops on yields have been conducted by several authors (Clark, 2007; Dabney et al., 2001, 2010; Marcillo and Miguez, 2017).

Instances of higher potato tuber yields following cover crops have been reported. For example, in Washington yields were 17\% higher following rapeseed (Brassica napus subsp. napus) (Boydston and Hang, 1995). In Colorado, yields were reported to range from $12 \%$ to $30 \%$ higher following the summer cover crop sorghum sudangrass (Delgado et al., 2007b). Cover crops have also contributed to higher yields of other vegetable crops. In California, although there were some reports of mixed results when using 
Brassica spp. cover crops in tomato (Solanum lycopersicum L.) cropping systems, a mixture of a legume with these Brassica cover crops can be used without impacting the marketable tomato yields (Hartz et al., 2005).

\subsection{Tropical regions}

In the tropics cover crops have the potential to contribute to increased yields of different crops. Lal et al. (1978) studied the potential to use perennial pasture leguminous cover crops and non-leguminous grasses cover crops in tropical cropping systems in Nigeria. They found that the molasses grass (Melinis minutiflora), perennial pasture legume Glycine wightii, perennial pasture legume centro (a.k.a. butterfly pea) (Centrosema pubescens), and perennial pasture legume tropical kudzu cover crops improved the properties of tropical soils by increasing organic $\mathrm{C}$, total $\mathrm{N}$, and cation exchange capacity (CEC) to a greater extent than not having a cover crop or than other cover crops that were studied. They also found that killing the cover crop to create a mulch increased soil water content and cooled the soil relative to the control.

Lal et al. (1978) also found that the fauna was affected, with the activity of earthworms being correlated with the amount of mulch produced and the persistence of the mulch residue. These changes in soil properties from the cover crops and most likely other factors that were not measured contributed to positive effects on the yields of corn, cowpeas (Vigna unguiculate L.), pigeon peas (Cajanus cajan L.), soybeans, and cassava (Manihot esculenta Crantz). They found that although there was variability in the cover crops' effects on the yields of these crops and some of the cover crops did not contribute to increased yields and in some cases may even have reduced the yield of a given crop, such as the negative effects on corn yield with the Guinea grass (a.k.a green panic grass) (Panicum maximum). Lal et al. (1978) found that centro, tropical kudzu, perennial pasture legume Stylosanthes guianensis, and congo grass (Brachiaria ruziziensis), increased the yields of these crops significantly.

Crusciol et al. (2015) conducted research studies with the cover crop palisadegrass in grain cropping systems of tropical areas of Brazil. They tested the effects of adding this palisadegrass on soil fertility, corn nutrient uptake and yield by comparing continuous corn vs corn with the use of this cover crop. For the cover crop study with palisadegrass the rotation in this area that was treated with the cover crops was as follows: corn inter-seeded with palisadegrass, and then only palisadegrass; and one more year of corn 
inter-seeded with palisadegrass, and then only palisadegrass. In the continuous corn rotation without the cover crop, the rotation was just one crop a year with corn; corn. After the cover crop palisadegrass, the rotation for the whole site went to two crops per year: soybean, white oat; soybean-white oat; and finally, corn. After 2 years of study they also monitored the areas where the palisade cover crop was planted with corn vs the continuous corn but they just grew for two additional years monitoring a rotation with soybean, white oat and back to corn. They found that the cover crop increased soybean, white oat, and corn yields and all have higher concentrations of macronutrients in the leaf.

Traill et al. (2018) conducted studies in Australia about the potential to integrate tropical forage legumes into cropping systems. The legumes studied were lablab, centro, butterfly pea (Clitoria ternatea), burgundy bean (Macroptilium bracteatum) and grain legume soybean. The rotation was forage legumes, oat cover crop, and then a corn grain crop. Similarly, in the same study a rotation of corn, oat cover crop and then a corn grain crop was monitored. The effects that a leguminous cover crop vs corn were having on the corn grain were monitored. The leguminous forage cover crops also had the treatments of harvested aboveground matter of the legume vs leaving all the aboveground biomass as a cover crop. Additionally, for the corn grain study, after the oat, the plots were split in four $\mathrm{N}$ rates, ranging from zero $\mathrm{N}$ fertilizer to $150 \mathrm{~kg} \mathrm{Nha}^{-1}$.

Traill et al. (2018) found that the effect of leaving the aboveground biomass of the leguminous forage butterfly pea, centro and lablab in the field was significant, since the corn grain yields were increased by $6-8 \mathrm{Mgha}^{-1}$ and $\mathrm{N}$ uptake was increased by $95-200 \mathrm{kgNha}^{-1}$ over the non-fertilized corn. In contrast, if the forage legume aboveground biomass was harvested, there was not any effect on the yield of corn. The only legume that had an effect when the aboveground biomass was harvested was centro, which increased the $\mathrm{N}$ uptake by $33 \mathrm{kgNha}^{-1}$.

The worst performer of all the leguminous cover crops was Burgundy bean, which did not have an effect on corn grain yields or $\mathrm{N}$ uptake with residue unincorporated or removed. Trail et al. (2018) concluded that in general for leguminous cover crops, when the aboveground biomass is incorporated the forage legume could contribute to higher yields, but since removing the aboveground forage diminishes the beneficial effects significantly, study of the grazing site of the forage cover crop and other new studies should be conducted. 
We propose that these studies suggest that the effect of the centro cover crop was due to significant $\mathrm{N}$ cycling from the belowground compartment and/or potential positive impacts on soil biological functions that contributed to higher yields of the following corn crop. For this tropical region in Australia, the addition of the $\mathrm{C}$ and $\mathrm{N}$ with the aboveground components of these cover crops contributed to $\mathrm{N}$ uptake as well as yields, which may have been increased not only by the cycling of $\mathrm{N}$, but most likely also by other positive effects from $\mathrm{C}$ additions on soil functions. However, the fact that the Burgundy bean cover crop did not have an effect on corn grain yields or $\mathrm{N}$ uptake with residue unincorporated or removed suggests that these cover crops also have effects on some biological functions that end up affecting the soil functions. This study shows that there are interactions between the types of cover crops, and some are more effective in increasing yields and $\mathrm{N}$ cycling than other cover crops. These results from Australia are another example of how important it is to apply the 4 Rs of cover crops when using them to adapt to a changing climate and to manage cropping systems by using the right cover crop, the right timing of placement, the right timing of killing, and the right management.

Tian et al. (1999) studied cover crop-fallow systems in the forest-savanna zone of southwestern Nigeria from 1992 to 1996. Tian et al. (1999) monitored the effects of corn-cassava intercrop every year (continuous cropping) and the effects of a corn-cassava-intercrop followed by second-year fallow with the natural growth, primarily christmas bush (a.k.a. siam weed, devil weed, common floss flower) (Chromolaena odorata), after the corn-cassava intercrop. They also monitored the effects of an improved system that will have a leguminous tropical kudzu cover crop. The leguminous cover crop was planted with a corn-cassava intercrop and then grown as a cover crop after harvesting the corn and cassava. No fertilizer was applied throughout the study.

Tian et al. (1999) found that the improved leguminous Pueraria cover crop residue fixed more atmospheric $\mathrm{N}$, adding $253 \mathrm{kgNha}^{-1}$, compared to the $109 \mathrm{kgNha}^{-1}$ fixed by the christmas bush. The $1992-96$ studies results found that the natural fallow, primarily christmas bush, increased the average corn yield by $75 \%$ to $350 \%$, and the cassava yield by $9 \%$ to $130 \%$ compared to continuous corn-cassava yields. The rotation with the improved leguminous cover crop tropical kudzu further increased the yields of corn by $22 \%$ to $72 \%$, which was higher than the natural fallow treatment with christmas bush. The effects of tropical kudzu on the intercropping 
cassava were mixed since the yields from 1992 to 1994 were lower but in 1996 the cassava yields were $41 \%$ higher. They also concluded that the leguminous cover crop tropical kudzu maintained the soil organic $\mathrm{C}$ better than the other treatments. They concluded that this improved leguminous cover crop could be a better management practice than a natural fallow crop.

The quantity of $\mathrm{N}$ fixed by the improved leguminous cover crop tropical kudzu in the forest-savanna zone of southwestern Nigeria was $253 \mathrm{~kg} \mathrm{Nha}^{-1}$ (Tian et al., 1999). The high $\mathrm{N}$ content of the leguminous cover crops in this region of Africa were similar to those observed for regions in Brazil. Perin et al. (2006) reported an $\mathrm{N}$ uptake with the leguminous cover crop sunn hemp of $305 \mathrm{kgNha}^{-1}$ from atmospheric and soil $\mathrm{N}$ sources in Vicosa, Brazil. In both studies, leguminous cover crops contributed to increased corn yields in a tropical region.

Velvet bean was introduced in Mesoamerica (Mexico, El Salvador, Costa Rica, Guatemala, Belize, Honduras, Nicaragua, Panama, Jamaica, Cuba, Haiti, Dominican Republic and Puerto Rico) in the 1920s and has been used with intercropping with corn as a cover crop and $\mathrm{N}$ source since then (Buckles, 1995). In some regions the cover crop velvet bean was planted during the rainy season, killed with a machete after 8 months, and followed with corn planted during the dry season with a stick used to make holes where the corn seed was planted (Buckles, 1995). The velvet bean would regrow and continue to supply atmospheric $\mathrm{N}$ to the corn with the intercropping of a leguminous crop and corn. A review of literature shows that in this region velvet bean could increase the yields of corn compared to fields that were not fertilized, and could potentially reach the yields of the fertilized corn grain (Buckles, 1995). Buckles (1995) found from interviews with local farmers in the region that velvet bean contributed to the improvement of soil properties by increasing soil fertility and reducing weeds.

Sotomayor-Ramirez et al. (2012) found that the leguminous cover crops velvet bean or cowpea ("Iron Clay") increased corn yields in the southern semiarid coast of Puerto Rico. The corn grain yield with the velvet bean cover crop $\left(2.9 \mathrm{Mgha}^{-1}\right)$ was higher than with the non-cover crop $\left(2.2 \mathrm{Mgha}^{-1}\right)$. Since the grain yield with the cowpea crop of $2.5 \mathrm{Mgha}^{-1}$ was not significantly different from the yield with the velvet bean or with corn after fall, Sotomayor-Ramirez et al. (2012) concluded that the leguminous cover crops in the southern semiarid coast of Puerto Rico contributed to higher yields.

Fofana et al. (2004) conducted studies with cover crops in southern Togo, located in west Africa. They studied the leguminous cover crop, 
velvet bean as a best management practice and they found that continuous corn in this region of west Africa will lead to lower yields and that cover crops are an alternative management practice for a more sustainable system. This corn-velvet bean intercropping system is established by planting corn at the onset of the rainy season (late April to mid-May) and 6 weeks later the macuna is planted in alternate rows between the corn plants. The study was conducted with different $\mathrm{N}$ rates $\left(0,50\right.$ and $100 \mathrm{kgNha}^{-1}$ and 0,20 and $40 \mathrm{~kg} \mathrm{Pha}^{-1}$ ) and with and without cover crop. Farmers in this region apply low $\mathrm{N}$ rates or do not apply $\mathrm{N}$ at all. The $100 \mathrm{~kg} \mathrm{Nha}^{-1}$ increased grain yields from 3.2 to $9.5 \mathrm{Mgha}^{-1}$ in 1999 , and from 8.6 to 13.9 in 2000 . The response to $\mathrm{N}$ fertilizer was higher than the response to the leguminous cover crop, but the leguminous cover crop shifted the response to $\mathrm{N}$ and contributed to higher NUE. Although the average yields increased with $\mathrm{P}$, there was not a significant response to P fertilizer. Fofana et al. (2004) proposed that those shifts in higher yields with the cover crops are due to other benefits that the leguminous cover crop is contributing, and not just the $\mathrm{N}$ added with the cover crop.

Ile et al. (1996) studied the effects of velvet bean (var. utilis) and $\mathrm{N}$ fertilizer on corn plant parameters and grain yields in Nigeria. At the beginning of the study the natural grass was mowed and the velvet bean was planted on the grass; in another set of plots the natural grass was allowed to regrow and some of the plots received $40 \mathrm{kgNha}^{-1}$ and another set was not fertilized. The corn was planted in the leguminous velvet bean, nonfertilized natural grass and the fertilized natural grass plots. Ile et al. (1996) found that the leguminous cover crop velvet bean increased the corn grain yields over the corn grown in the unfertilized natural grass. The corn grain yields were significantly higher in the fertilized natural grass. All grain yields were lower than $1 \mathrm{Mgha}^{-1}$. Ile et al. (1996) concluded that the velvet bean cover crops contributed to increased corn yields in the tropical acidic ultisol, but $\mathrm{N}$ fertilizer increased the yields to higher levels, though still below $1 \mathrm{Mgha}^{-1}$, showing that there is potential to apply other best management practices to increase the yields above $1 \mathrm{Mgha}^{-1}$.

Baijukya et al. (2005) conducted studies on the effects of the leguminous cover crops rattlepod (Crotalaria grahamiana Wight \& Arn), white hoarypea (Tephrosia candida DC.), and velvet bean on corn grain yields in Tanzania. The leguminous cover crops were compared to plots that received $50 \mathrm{kgNha}^{-1}$ and to a control plot without cover crops or $\mathrm{N}$ fertilizer. Baijukya et al. (2005) established plots adding differing amounts of residue of the white hoarypea crop residue $\left(2,4,6\right.$ and $\left.8 \mathrm{Mgha}^{-1}\right)$, creating a rate of 
$\mathrm{N}$ addition to the plots of 50, 100, 150 and $200 \mathrm{kgNha}^{-1}$. Baijukya et al. (2005) found that in the rainy and dry zones higher yields were obtained with the application of $\mathrm{N}$ fertilizer at a rate of $50 \mathrm{kgNha}^{-1}$, even though the $\mathrm{N}$ content of the leguminous cover crop residue was higher at an aboveground crop residue $\mathrm{N}$ content of up to $200 \mathrm{~kg} \mathrm{Nha}^{-1}$.

These studies with leguminous cover crops in Tanzania are similar to the leguminous cover crop studies in Brazil and other regions. Leguminous cover crops can increase the yields of corn significantly across these regions. However, higher yield tended to be achieved when corn following the leguminous cover crop was supplemented with inorganic $\mathrm{N}$ fertilizer.

The readily available $\mathrm{N}$ fertilizer (at a rate of $25 \%$ of the $\mathrm{N}$ returned to the soil with the cover crop residue) was applied in a split application of $25 \mathrm{kgNha}^{-1}$ four and 7 weeks after corn emergence (Baijukya et al., 2005). The corn grain yields were 3.2 and $3.1 \mathrm{Mgha}^{-1}$ with $50 \mathrm{kgNha}^{-1}$ inorganic $\mathrm{N}$ fertilizer for the rainy and dry zones. The yields from the different rates of the white hoarypea leguminous crop residue $\left(2,4,6\right.$ and $\left.8 \mathrm{Mgha}^{-1}\right)$, which were applied at an approximate $\mathrm{N}$ rate of $50-200 \mathrm{kgNha}^{-1}$ with the crop residue, ranged from 1.4 to $3.3 \mathrm{Mgha}^{-1}$ and from 2.0 to $2.8 \mathrm{Mgha}^{-1}$ for the rainy and dry regions, respectively. The applications of $2 \mathrm{Mgha}^{-1}$ of cover crops had no significant effects on corn grain yields, while applications of 4, 6 and $8 \mathrm{Mgha}^{-1}$ provided comparable yields to those of the $50 \mathrm{kgNha}^{-1}$ fertilizer. The apparent recovery of $\mathrm{N}$ from the white hoarypea cover crop residue was estimated at $27 \%$ and $13 \%$ for the high and low rainfall zones, respectively. Baijukya et al. (2005) found that mulching with velvet bean improved weed control by $49 \%$ and $68 \%$, increasing corn yields compared to weedy fallow. Baijukya et al. (2005) concluded that for degraded soils there is potential to manage cover crops to increase corn grain yields.

Chikowo et al. (2010) reported that the corn yields from 84 fertilizer studies in sub-Saharan Africa ranged from 0.3 to $7.7 \mathrm{Mgha}^{-1}$, with a mean $2.6 \mathrm{Mgha}^{-1}$ (standard deviation of 1.7), which was lower than the corn yields from 69 improved fallow/cover crops, which ranged from 0.3 to $8.2 \mathrm{Mgha}^{-1}$ with a mean of $2.1 \mathrm{Mgha}^{-1}$ (standard deviation of 1.5). The average corn yields for this region were low, and the average $\mathrm{N}$ availability with the cover crops $\left(146 \mathrm{kgNha}^{-1}\right)$ was higher than with the fertilizer $\mathrm{N}$ inputs $\left(94 \mathrm{kgNha}^{-1}\right)$; however, the $\mathrm{N}$ uptake appears to be higher for the inorganic $\mathrm{N}$ fertilizer than the cover crop, which were 53 and $48 \mathrm{kgNha}^{-1}$, respectively. Similarly, the average yields were higher with the inorganic fertilizer than the cover crops, which were 2.6 and $2.1 \mathrm{Mgha}^{-1}$, respectively. 
Chikowo et al. (2010) found that these yields are low, probably due to the fact that, as the authors reported, the studies were carried out in a system that has been degraded due to years of low fertility and lack of management practices to improve the fertility of these soils where the nutrients have been mined. Although there was not a statistical analysis presented of this metadata, the averages were most likely not significant due to such high variability and coefficients of variation of over $50 \%$. They found that there was poor correlation between yields and the availability of nutrients such as $\mathrm{N}$ and $\mathrm{P}$, most likely because there are many other factors that are limiting yield.

Chikowo et al. (2010) found a low correlation between $\mathrm{N}$ availability from cover crops and grain yield $\left(\mathrm{r}^{2}=0.16\right)$, while the correlation between the grain yield and $\mathrm{N}$ availability from fertilizer was higher $\left(\mathrm{r}^{2}=0.58\right)$. The maximum projected yield with the regression line was around $2 \mathrm{Mgha}^{-1}$ with the cover crops, which was about three times lower than the maximum projected grain yield with the regression line with the $\mathrm{N}$ fertilizer of about $6 \mathrm{Mgha}^{-1}$. Both of these regression lines ( $\mathrm{N}$ fertilizer line and cover crop line) ranged from low $\mathrm{N}$ availability (close to zero) to the same maximum $\mathrm{N}$ availability (close to $200 \mathrm{~kg} \mathrm{Nha}^{-1}$ ) of inorganic $\mathrm{N}$ fertilizer and improved fallows/cover crops $\mathrm{N}$. These results from analysis of the metadata from subSaharan Africa shows similar responses to other humid regions of Africa and in Latin America where leguminous cover crops increased yields but $\mathrm{N}$ fertilizer increased the yields to a greater degree. Occasionally, grain yields following cover crops without $\mathrm{N}$ fertilizer could reach the grain yields obtained with applied $\mathrm{N}$ fertilizer alone. However, responses across all these regions tended to be higher when grain crops followed a leguminous cover crop, or a mixture of leguminous and non-leguminous cover crops (or even on occasion, a non-leguminous cover crop) that was supplemented by inorganic $\mathrm{N}$ fertilizer. Thus, the literature suggests that the best practices for tropical regions that are not receiving excessive applications of $\mathrm{N}$ fertilizer, is to add $\mathrm{N}$ fertilizer to supplement the leguminous cover crop or selected cover crop at the site to increase the probability of higher yields.

\section{Not a silver bullet}

The effects of different winter cover crops (rye (Secale cereal L.) [7], triticale (a hybrid of wheat and rye; $\times$ Triticosecale) [2], and wheat [3]) on corn yields from a soybean-corn system in Iowa was studied by Kaspar and Bakker (2015). They reported that there were differences in corn cultivars' yields due to the winter cover crops and that in two of the 4 years the 
cover crop reduced the yields due to weather or environmental factors. Kaspar and Bakker (2015) found that there was a cover crop-cultivar interaction that is important to understand in these temperate soils of Iowa. We suggest that these interactions may be due to different impacts of cover crops on the soil biology that could potentially interact differently with the cultivars, and not just the change in soil chemistry alone (e.g., cycling of $\mathrm{N}$ and other nutrients) or soil physics (e.g., water availability). Findings by Kaspar and Bakker (2015) that cover crops can increase yields but can also contribute to lower yields also agree with findings by other scientists that cover crops have lowered yields due to different effects such as allelopathic effects or nutrient and water availability (Clark, 2007; Essah et al., 2012; ThorupKristensen et al., 2003; Unger and Vigil, 1998).

Several studies have shown that cover crops can reduce yields due to effects from crop residue with high $\mathrm{C}$ that can potentially reduce the availability of $\mathrm{N}$. Cover crops with high $\mathrm{C}$ to $\mathrm{N}$ ratios can contribute to immobilization of $\mathrm{N}$ for the subsequent crop, or use of water by the cover crop, which can reduce water availability in the soil profile, and in semi-arid and arid systems could potentially contribute to lower yield of the subsequent crop, or allelopathic effects (Kessavalou and Walters, 1997; Wagger and Mengel, 1993). However, using the 4 Rs of cover crops and management could help reduce the risk of decreasing the yields of the following crop (Delgado and Gantzer, 2015). As Delgado and Gantzer reported, "There is a need to use the right cover crop or cover crop mixture, select the right time to plant and harvest (or kill) the cover crop, and apply the right cover crop management practices at the right location, to increase the benefits of cover crops (the 4 Rs for cover crops)."

Managing the time of killing the cover crop could help keep the $\mathrm{C}$ to $\mathrm{N}$ ratios low. Using different cover crops with different times of killing the cover crop may also provide a management solution (Johnson et al., 1998). Growing mixtures of cover crops that have high $\mathrm{C}$ to $\mathrm{N}$ ratios such as growing non-leguminous grasses with leguminous cover crop grasses that have low $\mathrm{C}$ to $\mathrm{N}$ ratios will contribute to fixation of atmospheric $\mathrm{N}$ and cycling this $\mathrm{N}$ to the subsequent crop, reducing the potential for $\mathrm{N}$ immobilization. Additionally, the negative effects due to a high $\mathrm{C}$ to $\mathrm{N}$ ratio can be reduced with $\mathrm{N}$ fertilizer at planting (Vyn et al., 2000).

Kessavalou and Walters (1997) studied the effects of winter cover rye in Nebraska and assessed the effects of a rotation of corn following soybean with a winter rye cover crop, corn following soybean without rye and corn following corn, on corn grain yields. They observed reduction in yields in 1 
of 3 years due to the effects of the winter cover rye, but concluded that in general it was beneficial to include the winter cover rye in a corn-bean (Phaseolus vulgaris) rotation. The corn grain yields with the bean cover ryecorn or bean-corn were significantly higher for 3 years than the yields with the continuous corn. Only in one of the years did they observe a reduction due to the winter cover rye when the corn grain yields of the bean-winter cover rye-corn were lower than the bean-corn grain yields. They suggest that this could be due to an allelopathic effect from the winter cover rye.

Management decisions such as early killing of the cover crop (2-3 weeks before planting) has contributed to increased yields of corn for no-till and cultivated systems in Ontario, especially in drier years in no-till systems (WagnerRiddle et al., 1994). In Ontario, yields had been increased by killing the winter cover crop rye 2-3 weeks before planting, which could help in the decomposition of the crop residue. Several authors had reported that killing cover crops a couple of weeks before (or 1 week before) planting did not reduce the yields of a soybean crop in Illinois (Liebl et al., 1992; Ruffo et al., 2004), Canada (Wagner-Riddle et al., 1994), and Minnesota (De Bruin et al., 2005). Delgado and Follett (2002) reported that incorporation of organic sources such as crop residue and cover crops several weeks before planting can be used as a management tool to time and coordinate the release of nutrients, which can contribute to higher nutrient uptake and higher yields in the following crops (see Delgado and Follett, 2002; Figs. 2 and 3).

In arid and semiarid systems, the addition of cover crops to traditional wheat and fallow systems has the potential to reduce yields because the cover crop will use water resources that are needed in this semiarid system (Unger and Vigil, 1998). A potential management approach could be to use no-till and increase crop residue in the surface to increase the potential to reduce evapotranspiration (Farahani et al., 1998; Peterson et al., 1996 and Unger and Vigil, 1998).

Similarly to temperate regions, in tropical regions cover crops could also contribute to reduced yields, and management of cover crops needs to be considered when deciding how to use this tool. For example, MartínezMera et al. (2016) conducted cover crop studies in Puerto Rico in an Oxisol studying the effects of dwarf velvet bean and sunn hemp ("Tropic Sun") used for mulch in a no-till corn system vs a cultivated corn system. The cultivated system was fertilized with $56 \mathrm{kgNha}^{-1}$ while corn grown after the cover crops received zero $\mathrm{N}$ fertilizer. The average $\mathrm{N}$ input with the cover crop residue was $23 \mathrm{kgNha}^{-1}$ with velvet bean and $22 \mathrm{kgNha}^{-1}$ with sunn hemp. 
Martínez-Mera et al. (2016) found that the corn grain yields were 3, 2.5 and 3.7 $\mathrm{Mgha}^{-1}$ for the cultivated site with fertilizer for the first, second and third harvest, respectively. The leguminous cover crop did not increase the grain yields in the first $\left(2 \mathrm{Mgha}^{-1}\right)$ and second $\left(2.3 \mathrm{Mgha}^{-1}\right)$ corn harvest, and even reduced the grain yields in the third $\left(2.4 \mathrm{Mgha}^{-1}\right)$. This study suggests that dwarf velvet bean and the leguminous cover crop sunn hemp used as a mulch in no-till and used as the only source of $\mathrm{N}$ for corn grain production under an Oxisol does not maintain the productivity that can be achieved with inorganic $\mathrm{N}$ fertilizer in a cultivated Oxisol.

Chikowo et al. (2010) also found in a review of literature that in studies in sub-Saharan Africa, cover crops had average lower yields than the yields achieved with $\mathrm{N}$ fertilizer. They concluded that the yields were low because the studies were probably conducted in degraded systems. Similarly, Ile et al. (1996) studied the effects of Velvet bean (var. utilis) and $\mathrm{N}$ fertilizer on corn plant parameters and grain yields in Nigeria and found that the responses from fertilizer were also higher than the responses from the cover crop.

Afandi et al. (2002) reported that cover crops reduced erosion in coffee plantations in Indonesia, but at the expense of reduced yields. Afandi et al. (2002) reported that the tree coffee (Coffea arabica L.) yields as measured by Sriyani et al. (2000) were also reduced by 40\%. Afandi et al. (2002) reported there is a need for additional research on how to use cover crop management to reduce erosion while minimizing negative impacts on the coffee plant yields. They suggested that using cover crops in strips around the trees may be a potential alternative management practice to avoid the yield reduction caused by the cover crop, and that more research is needed on this potential management practice.

\section{Reduction of erosion and offsite transport of nutrients}

Montgomery (2007) reported that soil erosion is an important problem worldwide and that we need better agricultural methods to conserve soil. We could use cover crops to reduce soil erosion, improving soil quality and health in the face of a changing climate (Delgado et al., 2011; Lal et al., 2011). Cover crops can protect soil by reducing energy impacts at the soil surface from water flow and/or wind, as well as the kinetic energy from precipitation events (Bilbro, 1991; Decker et al., 1994; Frye et al., 1985; Holderbaum et al., 1990; Langdale et al., 1991; Woodruff and Siddoway, 1965). For intensive cropping systems in the arid and semiarid regions across 
North Dakota, Nebraska, Kansas, Colorado and Texas, no-till cover crops could be used to increase crop residue, water storage and $\mathrm{C}$ sequestration compared to the traditional wheat and fallow system (Peterson et al., 1996, 1998). Carbon sequestration can be increased with more intensive cropping systems than the traditional wheat and fallow (Black and Tanaka, 1997; Lyon et al., 1996). Merrill et al. (2006) reported that because this region is so susceptible to wind erosion, even with no till, a cover crop with high residue production could contribute to reduced erosion across this arid region.

Cover crops are a good tool to reduce erosion (Delgado et al., 1999; Kaspar et al., 2001; Lal et al., 1991; Langdale et al., 1991; Mutchler and McDowell, 1990; Wendt and Burwell, 1985; Zhu et al., 1989). For example, surface erosion due to precipitation events was reduced in Mississippi with winter cover crops in cultivated sites from 74 to $20 \mathrm{Mgha}^{-1} \mathrm{y}^{-1}$, and reduced the no-till erosion to less than $11 \mathrm{Mgha}^{-1} \mathrm{y}^{-1}$ (Mutchler and McDowell, 1990). Reducing erosion significantly reduces the offsite transport of $\mathrm{N}$ and other nutrients.

Cover crops are a good tool to reduce wind erosion, especially in semiarid systems, which are especially susceptible to wind erosion, particularly when early-planted or even late-planted winter cover crops are planted under vegetable systems such as lettuce (Lactuca sativa L.), or potato, which leaves significantly lower amounts of crop residue (Alsheikh et al., 2005; Delgado et al., 1999). One of the benefits of reducing long-term erosion is that the losses of soil organic carbon (SOC), $\mathrm{N}$, and macro- and micronutrients are significantly reduced (Alsheikh et al., 2005). Studies conducted in the Great Plains by Bilbro (1991) showed a significant reduction of wind erosion when winter rye was used.

Cover crops are a good tool for use across tropical regions with intensive precipitation to reduce water erosion. Studies conducted in West Java, Indonesia measured erosion rates as high as $94 \mathrm{Mgha}^{-1} \mathrm{yr}^{-1}$ for bare soil and $80 \mathrm{Mgha}^{-1} \mathrm{yr}^{-1}$ for clean-weeded cassava (van Dijk, 2002). The results of the studies show that these high rates of erosion could be reduced to $15 \mathrm{Mgha}^{-1} \mathrm{yr}^{-1}$ with mixed crops. The mixed intercropped systems studied were cassava, corn-rice (Oryza sativa) or cassava-corn and a legume (peanut). Rice and peanuts (Arachis hypogaea L.) were being used as cover crops when mixed with the corn and cassava, and although corn also provided some protection, the cassava did not. They also studied the use of mulch for these systems with high precipitation and found that mulch application at the start of the season could reduce the splash transport by $46 \%$ during the first couple 
of weeks (van Dijk, 2002). Mulch effectiveness was reduced significantly and they even found a higher rate of splash transport in the mulch treatment plots after 2 months, suggesting that live cover crops were a better system for protecting the soil.

van Dijk (2002) reported from some local old records that that had been collected, that the average rainfall for this region is above $2000 \mathrm{~mm}$, with some reported averages of 2947 and $2369 \mathrm{~mm}$ for two different sites. However, they had a drier season where average monthly rainfall was measured at less than $180 \mathrm{~mm}$ from July until September, and 1 year with $2650 \mathrm{~mm}$ fall in 176 days, which will contribute to high erosion potential. They reported that even under these extreme events, the use of cover crops was a good practice to reduce the offsite transport of soil via erosion.

Afandi et al. (2002) studied the potential to use cover crops in coffee plantations in Indonesia to reduce erosion. The rate of erosion was measured in coffee plantations without weeds, coffee with weeds, and coffee with carabao grass (a.k.a. hilo grass) (Paspalum conjugatum sp.) as the cover crop. Afandi et al. (2002) reported that the highest erosion rate was in the clean-weeded coffee plots, with an erosion rate of $22.4 \mathrm{Mgha}^{-1}$ during the second year of the study. The weed plots achieved minimal erosion loss (close to zero erosion loss) during the fourth year while the cover crop carabao grass achieved minimal erosion (zero) by the third year when all of the area was covered. Although it was reported that these cover crops or weeds will minimize soil erosion, this would be at a cost since the yields were significantly reduced. Afandi et al. (2002) reported that the yields as measured by Sriyani et al. (2000) were reduced by $70 \%$ in the weed plots and by $40 \%$ in the carabao grass cover crop plots. Cover crops used without any management will grow to compete with the coffee trees and will significantly reduce the yields, so there is a need to study how to manage these cover crops. Afandi et al. (2002) recommended that a potential alternative may be to plant the carabao grass cover crop in strips or around the coffee tree.

Schroth et al. (2001) reported that in large plantations the best management practice to minimize erosion during establishment of young trees is the use of a leguminous cover crop such as tropical kudzu or centro. Management of the cover crops will be required to avoid the cover crop climbing the trees if they are climbing legumes; they may also compete with the trees for water and nutrients and will need to be managed for establishment. Small farmers may plant food crops between the trees such as bananas (Musa sp.), rice, cassava or other crops. Schroth et al. (2001) concluded that in the humid tropics maintenance of soil fertility is better achieved in 
multistrata agroforestry systems than annual cropping systems because they have a lower erosion rate, and an environment that promotes soil biology processes because of the high rates of litter, yet degradation of soils in these multistrata agroforestry systems is observed repeatedly across tropical landscapes. Schroth et al. (2001) reported that to make these tree plantations economical, after a few years they can be replaced with permanent leguminous cover crops. In later years even timber trees can be incorporated to diversify the outputs from the land. In these systems Schroth et al. (2001) reported that leguminous crops could be a key management tool of these potential sustainable systems.

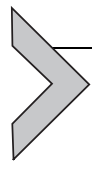

\section{Contribution to soil quality/soil health and sustainability}

Franzluebbers and Stuedemann (2015) studied cover crops in croplivestock systems in the southeastern United States and they found that cover crops can have a significant positive impact by serving as a key source of high quality forage between the short periods of cash crop, contributing to the sustainability of these systems. They reported that although the no-tillage cropping was the most effective way to preserve biologically active soil $\mathrm{C}$ and $\mathrm{N}$ fractions the biologically active fractions of $\mathrm{C}$ and $\mathrm{N}$ of the tillage systems were similar to those of the no-tillage systems at the surface $30 \mathrm{~cm}$. These studies are in agreement with several authors that had reported that use of cover crops in temperate and sub-tropical systems had increased the soil quality of the surface soils with higher C sequestration (Sainju et al., 2002, 2015).

One of the important components of soil health and soil quality is C sequestration, which contributes to feeding the soil microbial biomass. Six et al. (2006) found that cover crops and no till in a rotation can potentially impact soil biology and shift the soil microbial population to one dominated by fungus, which can potentially enhance the microbialderived C. Soil sustainability can be increased with cover crops, which help protect and improve the soil quality and the health of the soil resources (Bilbro, 1991; Dabney et al., 2001; Decker et al., 1994; Delgado et al., 2007a; Frye et al., 1985; Holderbaum et al., 1990; Langdale et al., 1991; Reeves, 1994; Thorup-Kristensen et al., 2003; Woodruff and Siddoway, 1965).

Sanginga et al. (1992) identified that soil organisms and cover crops were very important for maintaining the sustainability of cropping systems in the 
tropics. They reported that we could use management practices to control quantity, quality and timing of crop residues to manage soil biological processes that impact soil fertility. Sanginga et al. (1992) reported that soil biology is important for sustainability since it can contribute to $\mathrm{N}$ fixation, adding $\mathrm{N}$ to the system and helping take up other nutrients through mycorrhiza associations, and contributing to a better soil physical structure. A diversity of crops in the rotation with minimum tillage disturbance will benefit the soil fauna and microbial communities, helping achieve sustainability. Sanginga et al. (1992) reported on the importance of correlating biological factors such as microbial biomass, soil respiration, urease, phosphatase, glucosidase, dehydrogenase, mineralization potentials, lytic activities, earthworm castings, organic matter decomposition and important soil organisms with yields/productivity in tropical systems.

There is potential to use cover crops to increase crop intensity and diversity and add additional sources of $\mathrm{C}$ to the soils and improve soil health and soil biochemical properties (Dinesh et al., 2004). Dinesh et al. (2004) studied the potential to grow cover crops in 19-year old plantations of coconut (Cocos nucifera L.) in India. The study was assessed after the end of 10 years of using this practice, evaluating the potential to use the Atylosia scarabaeoides (L.) Benth. (a.k.a. Cajanus scarabaeoides (L.) Thouars), centro, a pasture legume Calopo (Calopogonium mucunoides) and tropical kudzu cover crops. They found that tropical kudzu, and Atylosia scarabaeoides were the cover crops with higher aboveground production. By using these cover crops, the soil fertility of the surface soils was significantly increased since for all the cover crops the phosphorus (P) Bray concentrations, soil organic $\mathrm{C}$ and total $\mathrm{N}$ as well as potassium $(\mathrm{K})$ concentrations were increased in the soil surface $(0-30 \mathrm{~cm})$ when compared to not using cover crops for these coconut plantations.

Dinesh et al. (2004) found that using these cover crops significantly contributed to improved soil health. The microbial biomass $\mathrm{C}$ and microbial biomass $\mathrm{N}$ were significantly increased by all the cover crops. Dinesh et al. (2004) conducted several soil health measurements and found that cover crops significantly increased all the biochemical variables that were used to assess microbial activity. For example, the microbial biomass $\mathrm{C}$ and $\mathrm{N}$, the $\mathrm{N}$ flush, the evolution of $\mathrm{CO}_{2}$, the $q \mathrm{CO}_{2}$ and ATP, as well as $\mathrm{N}$ mineralization, were increased. Additionally, the activities of enzymes such as dehydrogenase and catalase, were all higher with the cover crop treatments than the non-cover-crop treatments for these coconut systems. All kinds of enzymes (e.g., phosphomonoesterase, phosphodiesterase, 
arylsulfatase, beta-glucosidase, casein-protease, BAA-protease, urease, CM-cellulase, and invertase) were much higher under the cover crop treatments than the treatments not using cover crops.

Wang et al. (2008) studied the effect of sunn hemp "Tropic Sun" and cowpea "Iron Clay" as summer cover crops for nematode management in Hawaii. They found that sunn hemp did not enhance beneficial freeliving nematodes, but it was able to enhance bacterial-feeding nematode population densities that contributed to the suppression of root-knot nematodes in turnip, which is a host less susceptible to nematodes. Sunn hemp was not able to suppress nematode effects in the susceptible lima bean. These effects of cover crops show the potential to use these management practices as a soil health management tool that could control some of the soil biology to generate some positive effects with the turnip crop. In another study, Wang et al. (2003) found that the "Iron Clay" cowpea cover crop in Hawaii increased the yields of turnip (Brassica rapa) and basil (Ocimum basilicum), with this increase being partly due to suppression of the root-knot nematode, Meloidogyne incognita. The benefit of controlling the cover crop did not last long; it was only effective in one season of a vegetable crop, and the population of the nematode increased afterwards.

In the Cerrado of Brazil, Sarto et al. (2020) studied the effects of integrated crop-livestock systems (ICLS) in mitigating increased atmospheric $\mathrm{CO}_{2}$. One of the tools of the ICLS is the use of cover crops. They conducted studies on the effects of an 8-year-old ICLS where two species of Eucalypt (Eucalyptus grancam and Eucalyptus urograndis) were introduced into palisadegrass, a monoculture palisadegrass pasture, and a native savanna (Cerrado), to study the effects on soil biology. Planting Eucalyptus in the grass system increased the $\mathrm{C}$ and $\mathrm{N}$ content, similar to the native Cerrado savanna system and the monoculture pasture, increasing the sequestration of atmospheric $\mathrm{C}$ and recovering $\mathrm{N}$.

Sarto et al. (2020) found that there were some differences in soil biology such as a reduced microbial community composition and enzymatic activity ( $\beta$-glucosidase, acid phosphatase, and $\mathrm{N}$-acetyl glucosidase) near the Eucalyptus, which was increased in the pasture, probably due to lower water soil content because of the Eucalyptus. The Eucalyptus and monoculture grass had lower soil microbial biomass, actinomycete, gram-positive bacteria, $A M F$, and fungi abundance than the native Cerrado. This study shows that although there are some benefits due to increased $C$ sequestration with a silvopastoral system, these practices could also have impacts on aspects of soil biology. 


\section{Conservation of water quality}

Cover crops have been reported to function as scavenger crops capable of recovering nitrate from the soil profile and reducing the leaching of nitrate (Delgado, 1998, 2001; Delgado et al., 2001a,b; Kladivko et al., 2014; Meisinger and Delgado, 2002). Cover crops can be used to control weeds and reduce agrochemical use, improving water quality (Dabney et al., 2001). For temperate systems the time of planting and time of killing will affect the capacity of the cover crop to scavenge residual nitrate in the soil profile and the potential to reduce nitrate leaching. $N$ uptake of nonleguminous cover crops can be significantly affected by the residual soil nitrate in the soil profile and time of planting (Dabney et al., 2001; Delgado et al., 1999). Cover crops are excellent tools to reduce nitrate leaching; their deep-rooted systems serve as biofilters that scavenge nitrate from groundwater that is used for irrigation, from the whole profile and/or recover nitrate as it moves in the soil profile, contributing to improved water quality (Delgado, 1998, 2001; Delgado et al., 2001a,b).

In Colorado, the effectiveness of cover crops in recovering nitrate from the soil profile has been correlated with time of planting in the fall, with significant differences between early and late planting (Delgado, 1998). In these studies with winter wheat and winter rye, the $\mathrm{N}$ uptake of early planting was observed to be as high as 178 to $300 \mathrm{~kg} \mathrm{Nha}^{-1}$, several times higher than the $\mathrm{N}$ uptake when the winter cover crop was planted late, which was about $20 \mathrm{kgNha}^{-1}$ (Dabney et al., 2001; Delgado, 1998, 2001; Delgado et al., 1999, 2001a,b).

Komatsuzaki and Wagger (2015) reported that in a North Carolina Coastal Plain sandy loam soil cover crops planted after corn were significantly impacted by time of planting and termination. The $\mathrm{N}$ uptake for the early-planted (October) and early-terminated (mid-March) rye and black oat (Avena strigosa L.) was significantly higher than for the late-planted (November or December) and early-terminated (March) rye and black oat. For the early-planted (October) and late-terminated (late April/early May) wheat, a significantly higher $\mathrm{N}$ uptake of about $78 \mathrm{kgNha}^{-1}$ was observed.

The effectiveness in scavenging nitrate through the whole soil profile and reducing nitrate leaching has also been reported as being more dependent on soil depth than on root density (Delgado, 2001; Thorup-Kristensen, 2001). Thorup-Kristensen and Rasmussen (2015) reported differences in root depth among 20 different cover crops, as deep as $2.4 \mathrm{~m}$ measured 
(1.6-2.4 m) for dyer's woad (Isatis tinctoria L.) and viper's bugloss (Echium vulgare L.). The non-leguminous crops had greater root depths compared to leguminous cover crops. However, the $\mathrm{N}$ content of the legumes white clover (Trifolium repens L.), kidney vetch (Anthyllis vulneraria L.), and black medic (Medicago lupulina L.), which ranged from 170 to $202 \mathrm{~kg} \mathrm{Nha}^{-1}$, was almost double that observed in the non-leguminous cover crop $\left(105 \mathrm{~kg} \mathrm{Nha}^{-1}\right)$.

Shipley et al. (1992) conducted studies with ${ }^{15} \mathrm{~N}$ labeled $\mathrm{N}$ fertilizer and found that non-leguminous cover crops rye and annual ryegrass (Lolium multiflorum Lam.) recovered four to six times more $\mathrm{N}$ fertilizer (40-60\%) than the leguminous cover crops crimson clover (Trifolium incarnatum L.) and hairy vetch, which recovered only $10 \%$. Previous reviews of literature have reported that grasses can recover and scavenge more residual soil $\mathrm{N}$ than leguminous cover crops (Dabney et al., 2001, 2010; Meisinger et al., 1991). These reviews reported that the average nitrate leaching reduction for non-leguminous cover crops was about $70 \%$, more than three times the average $23 \%$ reduction in nitrate leaching with the leguminous cover crop (Dabney et al., 2001, 2010; Meisinger et al., 1991). Across the USA cover crops are powerful tools to reduce nitrate leaching. For example, in the Midwest cover crops can significantly reduce nitrate leaching and the leaching of water below the root zone (Kaspar et al., 2007; Rasse et al., 2000; Strock et al., 2004).

Several scientists have used models to evaluate the effects of winter cover crops on $\mathrm{N}$ use efficiencies and reduction of nitrate leaching. For example, Meisinger et al. (1991) used the Erosion Productivity Impact Calculator (EPIC) model to evaluate 10 sites across the USA and found that for the Midwest nitrate leaching can be reduced by close to $70 \%$. Malone et al. (2007) simulated a winter wheat cover crop in a corn-soybean rotation and found the nitrate leaching could be reduced by $38 \%$ in tillage systems. Li et al. (2008) used the model RZWQM-DSSAT to evaluate the effects of a rye winter cover crop and the nitrate leaching was reduced by $65-75 \%$.

In drier cropping systems that have higher evapotranspiration than precipitation and are semiarid, the potential for nitrate leaching in areas such as the northern Great Plains is minimal (Westfall et al., 1996; Williams and Kissel, 1991). Some of the irrigated systems of the western United States receive a lot of $\mathrm{N}$ when they are irrigated with groundwater that has already been contaminated with nitrate, and the background $\mathrm{NO}_{3}-\mathrm{N}$ in the irrigation water has been reported to range from 17 to $72 \mathrm{~kg} \mathrm{NO}_{3}-\mathrm{Nha}^{-1} \mathrm{y}^{-1}$ (Delgado and Follett, 2002). For these high-risk management-landscape 
systems, especially if they are irrigated systems under coarse-textured soils with high susceptibility, cover crops are a great tool to protect underground water resources (Delgado, 1998, 2001; Delgado et al., 1999, 2001a,b, 2006, 2007a,b, 2008).

There is significant potential for this background $\mathrm{NO}_{3}-\mathrm{N}$ from groundwater that is applied with irrigation water to be recovered, reducing the net $\mathrm{NO}_{3}-\mathrm{N}$ that is leaching from a system. For example, Mauch et al. (2008) found that most of the irrigation water when applied with a simulated center pivot irrigation system will go to the soil and will not be intercepted by the crop. Using ${ }^{15} \mathrm{~N}$ to trace fertigation of $\mathrm{N}$, Westermann et al. (1988) measured a recovery of $60-80 \%$, suggesting that as the crops develop their root systems they have the potential for higher potato uptake recoveries. Thus, crops with deeper root systems such as cover crops or other deep-rooted crops should respond similarly to the potato crop, with higher potential recoveries.

Cover crops are a useful tool to protect and improve groundwater quality since they can be used to prevent nitrate leaching and can also be used as filter strips to reduce the net nitrate leaching when the cropping systems are used with groundwater that contains high nitrate, having a net effect of mining nitrate from groundwater (Delgado, 1998, 2001; Delgado et al., 1999, 2007a). They end up increasing the $\mathrm{N}$ use efficiencies of these irrigated systems (Delgado, 1998, 2001; Delgado et al., 1999, 2001a,b, 2007a,b). Spatial variability in leaching, residual soil nitrate and $\mathrm{N}$ uptake was reported by Delgado $(1998,2001)$, who reported that these cover crops are an excellent tool to manage spatial and temporal variability of these irrigated systems, protecting groundwater quality (Delgado, 1998, 2001; Delgado et al., 2020). The use of cover crops and rotations of deep-rooted crops with shallower-rooted vegetable crops in south-central Colorado contributed to protection of groundwater quality with an estimated mining (extraction) of 11.1 metric tons of $\mathrm{NO}_{3}-\mathrm{N}$ from groundwater since 2001, and an estimated increase in yields and higher $\mathrm{N}$ use efficiencies worth over $\$ 109$ million (Delgado et al., 2020).

Another management alternative to reduce nitrate leaching is using limited irrigation. Cover crops with limited irrigation are a viable potential alternative to produce environmental benefits, by scavenging residual soil nitrate, reducing erosion, contributing to $\mathrm{C}$ sequestration and even increasing yields and cycling $\mathrm{N}$ and macro- and micro-nutrients to the following crop while minimizing the use of valuable irrigation water that could be used for the crops (Delgado et al., 2007a). Requiring 50-75\% less water to 
produce a viable summer cover crop than the water needed for other crops could provide biomass to feed animals or use as a green cover crop; either way, such an approach would contribute to environmental benefits via significant scavenging of nitrate available to leach, while still contributing to increased yields in the subsequent crop (Delgado et al., 2007a).

\section{Management and challenges}

\subsection{Water challenges}

Dabney et al. (2010) reported that optimal cover crop management varies by region and cropping system. It is clear that the management of cover crops requires the right approach, i.e., to "use the right cover crop or cover crop mixture with the right time of planting and harvesting (killing), with the right management practices, and at the right location to maximize the benefits of cover crops (the 4 Rs for cover crops)" (Delgado and Gantzer, 2015).

Although it has been reported that the history of cover crops originated in China and goes back over 3000 years (Lal, 2015), to increase the use of cover crops today, Lal (2015) recommended that we use payments for ecosystem services. Cover crops could be an important practice to help mitigate and adapt to climate change and increase $\mathrm{C}$ sequestration (Delgado et al., 2011; Lal et al., 2011). They can be used in trading ecosystem services such as reductions of direct and indirect $\mathrm{N}_{2} \mathrm{O}$ emissions, reductions of $\mathrm{NO}_{3}-\mathrm{N}$ leaching, and increases in $\mathrm{C}$ sequestration in water quality and air quality markets (Delgado et al., 2008, 2010a,b, 2011; Lal et al., 2011).

Independent of all these reports about the benefits of using cover crops at a farm level, Wallander (2013) reported that cover crop use was very low across U.S. cropland, with only $3-7 \%$ of farms incorporating these systems in their rotations. Recent research suggests the use of cover crops depends on farmers' perceptions about the use of cover crops. Arbuckle and RoeschMcNally (2015) reported that if farmers believe that there are benefits from using cover crops, this is positively correlated with cover crop use, while if farmers believe that there is a risk of using cover crops they will not adopt this practice. Thus, perceptions of the effects of cover crops on water balances and cost of the water resource are very important.

One of the factors in making management decisions about using cover crops and what cover crop to use and when to plant and kill a given cover crop is the water balance at a given site, especially for arid and semiarid systems. Cover crops can positively impact water availability because they can contribute to $\mathrm{C}$ sequestration, improving aggregation and water holding 
capacity as well as percolation, which can positively impact the water balance, especially if the cover crops are used with no till, and the crop residue mulch also contributes to reduced evapotranspiration. However, when they use available water that is stored in the soil profile, that could come at the expense of reduced yields of the subsequent crop, especially in arid and semiarid systems. The $4 \mathrm{Rs}$ for cover crops (the right cover crop [or mixture], at the right planting and killing time, with the right management and at the right location) are therefore of key importance.

Various scientists have reported on the effects of cover crops on soil water balances in the soil profile. Mitchell et al. (2015) conducted longterm studies (15 years) in the San Joaquin Valley of California and reported that cover crops will significantly reduce the water balance in the top $90 \mathrm{~cm}$ of the soil surface. They also reported that given the weather variability in this semiarid region vulnerable to drought, the aboveground biomass of the cover crop will significantly be affected by the weather, with significantly lower production in drier years, noting that although there will be some environmental benefits they will come at the cost of low water balances.

Mitchell et al. (2015) reported that even though there are some environmental benefits of using the cover crops, the fact that they are used in these drought-impacted, semiarid systems means its use comes at a high cost, since the next irrigated cash crop in these systems will need more water to replenish the dry soil profile after the cover crop and this will have a cost. Similarly, it has also been reported that in the Great Plains of the USA, cover crops use can potentially also deplete water resources and contribute to lower yields in the subsequent crop (Unger and Vigil, 1998).

Cover crops can have a positive impact on soil quality with respect to soil water storage, and several studies in California have found that cover crops can increase the soil water content and permeability in the soil system, increasing the water storage capacity of the soil (Colla et al., 2000; Joyce et al., 2002). Management of water could also become an issue when using furrow irrigation since the permeability of water in the soil profile may increase due to the use of cover crops, so drip irrigation systems may be better management options to improve the water quality in management systems that use cover crops since drip irrigation will contribute to a lower nitrate leaching potential (Colla et al., 2000; Islam et al., 2006; Joyce et al., 2002). This is also another example showing that managing cover crops is complex and should consider the $4 \mathrm{Rs}$ of cover crops, as well as improved water management, to reduce environmental impacts. 


\subsection{Weeds and nematode management}

Abdul-Baki et al. (2005) conducted cover crop studies in nematode-infested fields in southern Florida. They studied the effect of cover crops (cowpea "Iron Clay"), velvet bean and sunn hemp (cv. Tropic Sun) on a tomato crop. Abdul-Baki et al. (2005) conducted an economic analysis of the use of these cover crops for tomato production in this region of Florida. Their economic analysis found that all cover crops achieved net economic returns in all years, with sunn hemp having the highest yields and highest economic returns.

Chikoye et al. (2005) studied the potential to use the cover crop velvet bean to control weeds in Nigeria. Chikoye et al. (2005) found that dry biomass (shoot_rhizome) of the congo grass was significantly reduced with the use of the leguminous cover crop alone compared to the control with no tillage, no glyphosate, and no velvet bean. However, the effect of the leguminous cover crop was to reduce the yield compared to the control with no cover crop use.

\subsection{Salinity and grazing challenges}

Mitchell et al. (1999) reported that when salinity is a problem brassica species and triticale are cover crops with salinity resistance and they can produce significant amounts of biomass under these conditions, suggesting they can be potential management tools in saline systems. Cover crops can be used for grazing, but when these crops are grown in soils with high residual soil nitrate, there is potential to increase the nitrate concentrations to levels that could be potentially toxic to animals (Delgado et al., 1999; Tucker et al., 1961). Stanton (1994) reported that dry weight $\mathrm{NO}_{3}-\mathrm{N}$ concentrations of 1150-2300 ppm are mildly toxic to livestock, and above $2300 \mathrm{ppm}$ the forage presents a danger to them. Concentrations of winter cover rye grown after spinach that left large concentrations of $\mathrm{NO}_{3}-\mathrm{N}$ in the soil profile were measured as high as $3500 \mathrm{ppm}$ in dry weight $\mathrm{NO}_{3}-\mathrm{N}$ concentrations.

\subsection{Social challenges to adoption}

The tropics have some social challenges with respect to adoption of cover crop use similar to those of temperate regions. For example, Erenstein (2003) reported that the adoption of cover crops mulching by smallholders in the tropics is affected by several social factors that will significantly impact the degree to which these customers will incorporate this practice and will depend on, among other factors, farmers' perceptions. Highlighting several promising experiences for smallholders across the tropics, particularly in 
sub-humid regions, Erenstein (2003) reported that crop residue mulching can contribute to higher income due to savings with reduced tillage, and that it could generate other benefits due to water conservation and reduced time needed for land preparation and crop establishment. The economic impact will not only depend on the cost savings from not needing to use planting equipment, but also on the cost of new, adapted seeding equipment, and the cost of controlling weeds, pests and diseases with a new, no-till system. Erenstein (2003) reported that it will also require other changes, including investments and institutional change. It also appears to be viable in humid tropics where land availability is low, and where the farmer has property rights over residual crop biomass and land (Erenstein, 2003).

Cover crop mulching can help smallholder farmers address soil fertility and weed management constraints, but the benefits of cover crop mulching seem to be limited to sub-humid zones and to cases where there is relatively low opportunity cost from using land to grow cover crops. Nonetheless, there is potential to use it in agricultural systems with limited external input use and/or periodic fallowing. The investment required for cover crop mulching is a barrier to entry. The viability of mulching cover crops relies heavily on, among other factors, retention of property rights over residual crop biomass. Erenstein (2003) reported that in order for smallholders to get to used to this practice of mulching cover crops, an integrated approach with a practical orientation, farmer participation, as well as an involvement of the community is needed. Smallholder farmers will need to approach this change with a long-term perspective and be flexible as the conservation practice is incorporated into routine operations (Erenstein 2003).

Ganry et al. (2001) conducted a review of literature of management practices that have been used to manage SOM in semiarid Africa. They concluded in their review of literature that there is a need to improve the management of all types of SOM input into the soils of semiarid Africa. Among the best management practices that they reviewed was improved fallows and use of cover crops. They reported that biomass for improved systems could be achieved with agroforestry and use of cover crops but that management of cover crops was not well understood in relation to precipitation and soil type (Ganry et al., 2001). Examples of the drier regions where cover crops have been used successfully were Mali, northern Nigeria, Burkina-Faso and Senegal (Ganry et al., 2001).

Examples for grassing systems were using lablab and Stylosanthes hamata for improved quality. Grassing systems have also been improved by controlling witchweed (Striga spp.) with porcupine jointvetch (Aeschinomene 
histrix), which also improves the quality of grassing (Ganry et al., 2001). There were more research needs identified as far as the potential use of cover crops for human and animal feed. For this region of Africa with soils that have been degraded, the establishment, use and management of cover crops have not been mastered, and additional research is needed to understand the interactions of weather, rotations, soil type and other parameters.

Schroth et al. (2001) noted that among the research questions that needed to be answered were: (a) how will social aspects of limited markets and credits impact the potential to develop these multi-strata systems under infertile soils; (b) how the severity of extreme climate impacts such as droughts will be managed in space and time; and (c) how the management practices could contribute to optimization of the effects of biological processes in increasing organic matter fauna and microflora.

Chibarabada et al. (2017) concluded that there is a large prevalence of food and nutrition insecurity across the semi-arid and arid tropics and additional research is needed to improve the understanding of the value chain and use of these leguminous crops to identify what is limiting the potential benefits of these cover crops. Chibarabada et al. (2017) reviewed the literature about the potential value of grain legumes for the semi-arid and arid tropics. They reported there is a need for additional research, development, and innovation related to minor grain legumes, especially of those that may have shown that they are adapted to local conditions even when they are stressed with droughts and may have better responses than other, more frequently used legumes. They also reported that farmers face large constraints due to the low fertility of the soils in these regions and that there is a lack of and need for research on how to make viable recommendations to farmers in these degraded soils to optimize the crop water productivity. There is a need to expand the portfolio of options for local farmers and to conduct research that is lacking on the minor indigenous legumes that are currently being used and that have already been shown are adapted to drought events that occurred across these semi-arid and arid tropical regions.

These challenges of food security for the arid and semiarid tropics as well as periods of droughts could also be applied to other humid regions that are being impacted by a changing climate and droughts. For example, Álvarez-Berríos et al. (2018) reported that the droughts of the first two decades of the 21 st century throughout the Caribbean region show the vulnerability of this region to changes in climate and the increasing need in this region for practices that could contribute to climate change adaptation to maintain the needed agricultural production. In their concluding remarks 
they reported that one of the major challenges faced by tropical farming systems is the occurrence of agricultural droughts. Álvarez-Berríos et al. (2018) reported that since droughts are projected to increase in Puerto Rico, it will be necessary to adapt to these projected changes and the island needs to implement more conservation practices in these areas that will be affected by drought intensification and exposure.

\section{Carbon sequestration}

In temperate systems cover crops can be used as a tool to increase $\mathrm{C}$ sequestration and improve soil quality and health (Alsheikh et al., 2005; Clark, 2007; Sainju et al., 2002; Sarrantonio, 2007). Sainju et al. (2015) reported that a combination of hairy vetch/rye increased the $\mathrm{C}$ sequestration and storage of $\mathrm{N}$ in bioenergy sorghum systems of the southeastern United States. We could use cover crop systems to maintain or even increase C sequestration (Alsheikh et al., 2005; Clark, 2007; Lal, 2002; Sainju et al., 2002; Sarrantonio, 2007).

Similarly, in tropical systems cover crops have been reported to contribute to increased $\mathrm{C}$ sequestration and improved soil health and soil quality (Lal, 2002). Zhou et al. (2011) studied the short-term effects of wheat and Saia oat cover crops in Australia. They found there was rapid decomposition of the crop residue and that cover crops increased soil labile organic C pools. Dinesh et al. (2009) studied the effects of the Atylosia scarabaeoides (L.) Benth., centro and tropical kudzu cover crops on microbial activity in a coconut farm in India. They found that the cover crops increased the total $\mathrm{N}(\mathrm{TN})$, organic $\mathrm{C}(\mathrm{OC})$, dissolved organic $\mathrm{C}$ (DOC) and $\mathrm{N}(\mathrm{DON})$, and labile organic $\mathrm{N}(\mathrm{LON})$. They concluded that cover crops, especially tropical kudzu or Atylosia scarabaeoides (L.) Benth, significantly enhanced the levels of OC, $\mathrm{N}$ and microbial activity down to the top $50 \mathrm{~cm}$ of soils. Another study from India conducted by Pandey and Begum (2010) found that cover crops should be used as a management tool for coconut plantations and other similar agroecosystems in the humid tropics to increase mineralization of soil $\mathrm{N}$ and enhance soil $\mathrm{C}$ sequestration.

Barthès et al. (2004) used ${ }^{13} \mathrm{C}$ natural abundance to assess the potential of $\mathrm{C}$ sequestration of a leguminous cover crop (velvet bean var. utilis) in Benin. Using the ${ }^{13} \mathrm{C}$ natural abundance technique, they were able to account for the sources of $\mathrm{C}$ residue that were contributing to $\mathrm{C}$ sequestration in a no-till continuous corn rotation, and a continuous corn rotation with association with a leguminous cover crop (velvet bean var. utilis with corn). Another 
rotation that was monitored in this study was a continuous cultivated rotation fertilized with $\mathrm{N}, \mathrm{P}$, and $\mathrm{K}\left(200 \mathrm{kgha}^{-1}\right.$ of a compound fertilizer N-P-K [15-15-15], and $100 \mathrm{kgha}^{-1}$ of urea).

Barthès et al. (2004) found that with the ${ }^{13} \mathrm{C}$ natural abundance the contribution from the high residue cover crop to $\mathrm{C}$ sequestration was a rate of $1.3 \mathrm{MgCha}^{-1} \mathrm{y}^{-1}$ over the 12-year period. Barthès et al. (2004) concluded that leguminous cover crops are a great management practice to sequester atmospheric $\mathrm{C}$ at higher rates than was observed for the corn (0.2 $\mathrm{MgCha}^{-1} \mathrm{y}^{-1}$ over the 12 years) or with the fertilized and cultivated corn that was losing soil organic $\mathrm{C}$ derived from corn at a rate of $0.2 \mathrm{MgCha}^{-1} \mathrm{y}^{-1}$ over the 12 years. The average crop residue $\mathrm{C}$ derived from aboveground and belowground plant compartments of corn, weeds and/or leguminous cover crop returned to the soil was 3.5, 6.4 and 10.0 $\mathrm{MgCha}^{-1} \mathrm{y}^{-1}$ over the 12 years for the traditional corn without fertilizer and no till, tilled and fertilized corn, and the no-till corn in association with the leguminous cover crop, respectively. The soil $\mathrm{C}$ that was derived from corn in the study was less than $40 \% \mathrm{C}$ of the new corn residue added, which was much lower than the greater-than $-50 \% \mathrm{C}$ from the crop residue of the leguminous cover crop. The conclusion was that although the $\mathrm{N}$ fertilizer contributed to a greater amount of corn biomass returned to the soil, the loss is attributed to a greater mineralization of the crop residue due to the stimulus that $\mathrm{N}$ will have to increase mineralization.

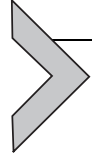

\section{Case scenario from the Ecuadorian Andes}

\subsection{New cover crops, residue management and no-till system}

The Andean region of South America is a region impacted by cultivation, which is increasing the potential for soil erosion since large areas of the cultivated soils are under slopes that have high erosion potential (Barrera et al., 2019; Delgado et al., 2019; Monar et al., 2013; Figs. 4 and 5). This high erosion potential is decreasing the sustainability of these systems and diminishing the potential to achieve food security, especially when farm areas are eroded to the point that the subsoil is exposed or the gravelly parent material may be exposed, significantly reducing soil health and soil quality (Barrera et al., 2019; Chela, 2008; Delgado et al., 2019; Dourojeanni and Jouravlev, 2001; Monar et al., 2013). Fig. 4 shows exposed subsoil areas impacted by erosion in Andean regions of Ecuador and Bolivia. 


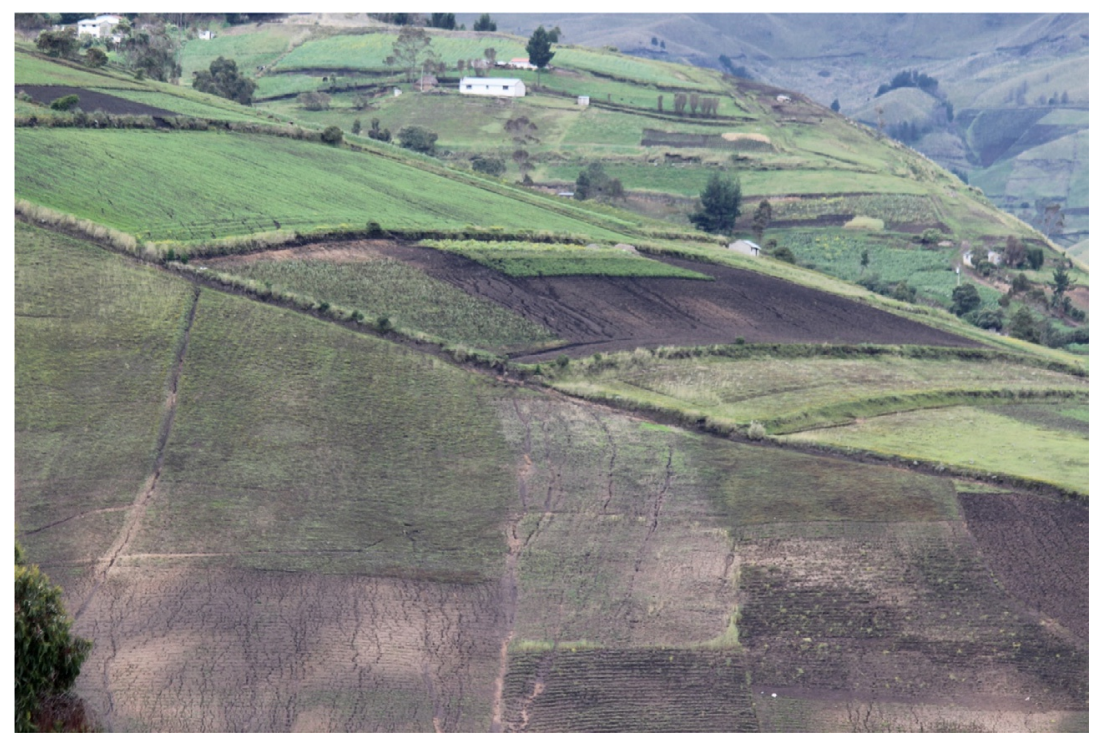

Fig. 4 Soil erosion is an obvious problem across the traditional cropping systems of Andean regions in Ecuador. This erosion in these high slopes is contributing to large losses of soil, which are exposing the less productive subsoil (whiter areas in the picture). See the formation of ephemeral gullies from the higher to lower areas due to high erosion rates across the cropping systems. Note: Photo by Jorge A. Delgado, USDA Agricultural Research Service.

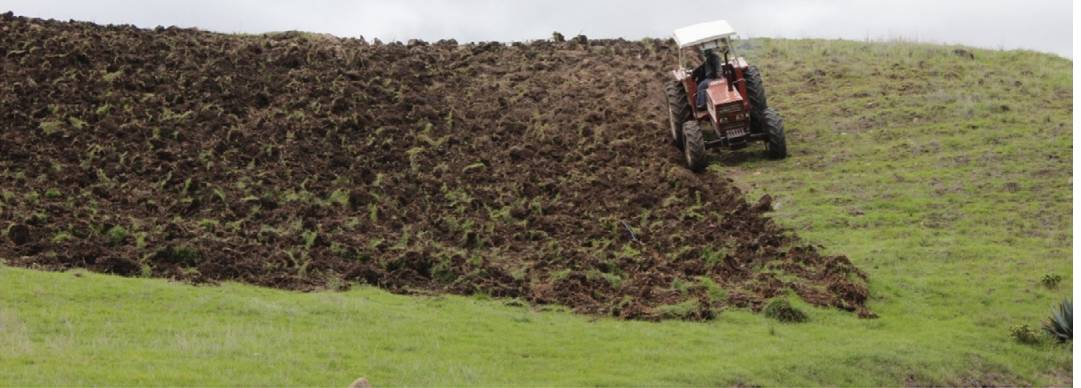

Fig. 5 Example of mechanical plowing down the hill in high-altitude soils of the Ecuadorian Andean region. Notice that the plowing is down the slope, increasing the potential for soil erosion. Plowing increases the loss of the surface soil, exposing the less productive subsoil. Note: Photo by Jorge A. Delgado, USDA Agricultural Research Service. 
Barrera et al. $(2010,2012)$ reported that for this Andean region of Ecuador the majority of the rural population is living in extreme poverty, lacking access to loans, banking systems, and agricultural technologies, as well as the support of extension services that could help increase agricultural productivity and their economic status. Agriculture in this region continues to rely on plowing by animals and machinery on slopes up to 50 degrees, which have high erosion potential, especially after plowing when the soil is uncovered and exposed (see Fig. 5). Erosion for these regions has been reported at rates up to $150 \mathrm{Mgha}^{-1}$, which can contribute to rapid degradation of these valuable resources, contributing to lower yields and degraded soil health, even exposing the parent material and/or subsoil (Figs. 4 and 5) (Chela, 2008; Dourojeanni and Jouravlev, 2001).

INIAP has been conducting research on conservation agriculture for over a decade, assessing the potential for using conservation agriculture, reduced tillage, decreased crop residue removal, cover crops, and other conservation practices to improve yields while minimizing erosion and increasing sustainability and potential for climate change adaptation (Barrera et al., 2012; Escudero et al., 2014). The studies conducted and some of the unpublished data presented in this article cover some of these efforts by INIAP in cooperation with SANREM, Virginia Tech, USDA-ARS, USAID and Penn State and other U.S. and Ecuadorean institutions. The practices have been conducted in three watersheds in the Andean region of Ecuador, and have the potential to impact 200,000 farmers.

Delgado et al. (2019) conducted a 5-year study to assess the effects of tillage, crop residue management, and $\mathrm{N}$ fertilization on yields and economic returns. For Phase 2, they found that for five out of the five crops when the crop residue was left at the surface, the yields were higher than those when the crop residue was harvested, but only two were significant. The plots treated with $\mathrm{N}$ fertilizer had significantly higher yields in four out of five crops.

Adding $\mathrm{N}$ fertilizer significantly increased the economic returns compared to not adding $\mathrm{N}$ fertilizer (Delgado et al., 2019). In these studies, adding $\mathrm{N}$ fertilizer in the first year significantly increased the yields of the corn (2012), bringing them to $4.1 \mathrm{Mgha}^{-1}$, which is higher than the $3.9 \mathrm{Mgha}^{-1}$ yields of the non-fertilizer corn plots. The corn was followed by an oat/vetch (2013), bean (2013), oat/vetch (2014) and corn (2014) rotation. The fertilized corn plots received $80 \mathrm{kgNha}^{-1}$, while the $\mathrm{N}$-fertilized bean plots received an $\mathrm{N}$ application rate of $40 \mathrm{kgNha}^{-1}$. Both oats/vetch crops were not fertilized. Although Delgado et al. (2019) found a corn grain 
yield response to $\mathrm{N}$ fertilizer in 2012 , the fertilized plot yields $\left(4.3 \mathrm{Mgha}^{-1}\right)$ were not significantly different from the non-fertilized corn grain yields $\left(4.2 \mathrm{Mgha}^{-1}\right)$ in 2014 .

These studies by Delgado et al. (2019) suggest that a significant amount of the aboveground and belowground crop residue $\mathrm{N}$ in the oat/vetch and bean and oat/vetch was cycled to the 2014 non-fertilized corn crop. The 2012 fertilized corn crop responded to the $\mathrm{N}$ application, even though it was following a 2012 oat/vetch crop. This suggests that with time the oat/vetch could be increasing the $\mathrm{N}$ pools in the soil, or that there is a potential year-crop residue interaction that generated enough $\mathrm{N}$ in 2014 that there was no difference between the fertilizer and non-fertilizer corn yields. Although soil $\mathrm{N}$ was not measured, we propose that conservation agriculture with no-till and minimum till, and rotations of oat/vetch cover crops and leguminous crops could be increasing the SOM N pools, and the cycling in 2014 was equivalent to the positive effects of the $80 \mathrm{~kg} \mathrm{~N}$ fertilizer when there was no difference between the fertilized and non-fertilized corn plots.

An additional finding by Delgado et al. (2019) supporting the concept of $\mathrm{N}$ cycling from these cover crops is that the 2012 corn grain yields $\left(4.2 \mathrm{Mgha}^{-1}\right)$ in the plots with no crop residue harvested were higher than the corn grain yields $\left(3.8 \mathrm{Mgha}^{-1}\right)$ in the plots with crop residue harvested, suggesting that keeping all the aboveground oat/vetch (2011 and 2012) crop in the field significantly increased the corn grain yields. In 2014 the corn grain yields $\left(4.3 \mathrm{Mgha}^{-1}\right)$ in the plots with no crop residue harvested were not significantly different than the corn grain yields $\left(4.2 \mathrm{Mgha}^{-1}\right)$ in the plots with crop residue harvested. Since there was not a response to $80 \mathrm{~kg} \mathrm{Nha}^{-1}$ of $\mathrm{N}$ fertilizer, this suggests that after 4 years the belowground $\mathrm{N}$ material from these cover crops with minimum tillage and zero tillage was enough to increase the yields significantly, to levels equivalent to $80 \mathrm{~kg} \mathrm{Nha}^{-1}$ of $\mathrm{N}$ fertilizer. Additionally, the average corn grain yields in the plots in 2010 were $3.1 \mathrm{Mgha}^{-1}$, and by 2012 the yields were increased to $4.1 \mathrm{Mgha}^{-1}$ with conservation agriculture and $4.3 \mathrm{Mgha}^{-1}$ in 2014 , suggesting that conservation agricultural practices with these cover crops can contribute to increasing the corn yields by $25 \%$. Similar positive responses to conservation agriculture and cover crops were also measured for potato. Yields were increased by an average of $37 \%$ across the Paute and Sicalpa watersheds from 2015 to 2018 (Tables 1 and 2). Such responses show the potential for these practices to adapt to a changing climate. With that said, there is a need to establish long-term studies to monitor how yields may change over a longer period of one or two decades. 
Table 1 Treatments that were monitored at three different watersheds in the Andean region of Ecuador, 2011-19 .

Watershed Crop rotation $\quad$\begin{tabular}{l}
$\begin{array}{l}\text { Conservation agriculture } \\
\text { treatments }\end{array}$ \\
\hline
\end{tabular}

Illangama $^{\mathrm{b}} \quad$ Potato (2011)-oat/vetch Conservation practice of water

(2011-14) (2011)-barley (2012)—faba bean (2013)_forage (2014) deviation ditches (with ditches and without ditches); tillage (conventional tillage and minimum tillage); residue management (residue harvested and no residue harvested); nitrogen management (with nitrogen fertilizer and no nitrogen applied)

Sicalpa

(2015-19)
Potato (2015) —oat/vetch (2016) - barley (2016) —faba bean (2017) —oat/vetch (2017) — potato (2018) forage (2018-19)
Conservation practice of water deviation ditches (with ditches and without ditches); tillage (conventional tillage and minimum tillage); residue management (residue harvested and no residue harvested)

Tillage (conventional tillage and minimum tillage); residue management (residue harvested and no residue harvested)

\footnotetext{
${ }^{\mathrm{a}}$ For the treatments with residue (no residue harvested), the product was harvested, and the crop residue was left on the ground, including whole forage that was left in the field (oat-vetch and forage crops with residue). In treatments without residue (residue harvested), the product was harvested and the remaining residue was removed from the plots. For the oat-vetch, forage was cut and removed from the plot for animal feeding. For barley, the whole plant was cut and removed for threshing. The faba bean crop was harvested and the residue was left in the field. Finally, in the case of pasture, forage was cut on all parcels and withdrawn for animal feeding.

${ }^{\mathrm{b}}$ Barrera et al. (2019).
}

The economic analysis conducted by Delgado et al. (2019) of the fivecrop rotation reflects an advantage to fertilizing the corn and bean crops. The net income of adding $\mathrm{N}$ fertilizer was 500.00 US dollars ha ${ }^{-1}$. However, harvesting crop residue provides an advantage of 900.00 US dollars $\mathrm{ha}^{-1}$, while zero tillage provided an advantage of $300 \mathrm{US} \mathrm{dollars} \mathrm{ha}^{-1}$ vs minimum tillage. These studies found that zero tillage and crop residue removal with $\mathrm{N}$ fertilizer were the most economical, but the data also suggested that there is some recycling of $\mathrm{N}$ or other benefits of the cover crops in non-fertilized corn systems and that implementation of these practices with improved 
Table 2 Effect of crop residue management ${ }^{a}$ on average yields $\left(\mathrm{Mgha}^{-1}\right)$ for the different crops, including cover crops grown in the Illangama, Sicalpa and Paute watersheds in Andean regions of Ecuador ${ }^{b}$.

\begin{tabular}{|c|c|c|c|c|c|}
\hline \multirow[b]{2}{*}{ Treatment } & \multicolumn{5}{|c|}{ Average yields $\left(\mathrm{Mgha}^{-1}\right)$ in Illangama watershed ${ }^{\mathrm{c}}$} \\
\hline & $\begin{array}{l}\text { Potato } \\
2011\end{array}$ & $\begin{array}{l}\text { Oat/vetch } \\
2011\end{array}$ & $\begin{array}{l}\text { Barley } \\
2012\end{array}$ & $\begin{array}{l}\text { Faba Bean } \\
2013\end{array}$ & $\begin{array}{l}\text { Forage } \\
2014\end{array}$ \\
\hline $\begin{array}{l}\text { No residue } \\
\text { harvested }\end{array}$ & $15.2 \mathrm{a}$ & $43.4 \mathrm{a}$ & 2.0 & $2.6 \mathrm{a}$ & 12.0 \\
\hline $\begin{array}{l}\text { Residue } \\
\text { harvested }\end{array}$ & $12.9 \mathrm{~b}$ & $41.2 \mathrm{~b}$ & 1.9 & $2.4 \mathrm{~b}$ & 12.0 \\
\hline
\end{tabular}

\begin{tabular}{llllllll}
\hline & \multicolumn{6}{c}{ Average yields $\left(\mathrm{Mg} \mathrm{ha}^{-\mathbf{1}}\right)$ in Sicalpa watershed } \\
\cline { 2 - 8 } & $\begin{array}{l}\text { Potato } \\
\mathbf{2 0 1 5}\end{array}$ & $\begin{array}{l}\text { Oat/vetch } \\
\mathbf{2 0 1 6}\end{array}$ & $\begin{array}{l}\text { Barley } \\
\mathbf{2 0 1 6}\end{array}$ & $\mathbf{2 0 1 7}$ & $\mathbf{2 0 1 7}$ & $\mathbf{2 0 1 8}$ & $\mathbf{2 0 1 8 - 1 9}$ \\
\hline $\begin{array}{l}\text { No } \\
\text { residue } \\
\text { harvested }\end{array}$ & 16.9 & $25.6 \mathrm{a}$ & $3.0 \mathrm{a}$ & $12.1 \mathrm{a}$ & $21.3 \mathrm{a}$ & $26.2 \mathrm{a}$ & $28.4 \mathrm{a}$ \\
\hline $\begin{array}{l}\text { Residue } \\
\text { harvested }\end{array}$ & 17.7 & $23.8 \mathrm{~b}$ & $2.7 \mathrm{~b}$ & $10.5 \mathrm{~b}$ & $18.7 \mathrm{~b}$ & $24.0 \mathrm{~b}$ & $25.8 \mathrm{~b}$ \\
\hline
\end{tabular}

\begin{tabular}{lllllll}
\hline & \multicolumn{5}{c}{ Average yields $\left(\mathrm{Mg} \mathrm{ha}^{-\mathbf{1}}\right)$ in Paute watershed } \\
\cline { 2 - 7 } & $\begin{array}{l}\text { Potato } \\
\mathbf{2 0 1 5}\end{array}$ & $\begin{array}{l}\text { Oat/vetch } \\
\mathbf{2 0 1 6}\end{array}$ & $\begin{array}{l}\text { Arveja } \\
\mathbf{2 0 1 6}\end{array}$ & $\begin{array}{l}\text { Sweet Corn } \\
\mathbf{2 0 1 7}\end{array}$ & $\begin{array}{l}\text { Potato } \\
\mathbf{2 0 1 8}\end{array}$ & $\begin{array}{l}\text { Forage } \\
\mathbf{2 0 1 8 - 1 9}\end{array}$ \\
\hline $\begin{array}{l}\text { No residue } \\
\text { harvested }\end{array}$ & 17.9 & 47.6 & 6.7 & 21.6 & $24.0 \mathrm{a}$ & $42.0 \mathrm{a}$ \\
\hline $\begin{array}{l}\text { Residue } \\
\text { harvested }\end{array}$ & 16.4 & 45.4 & 6.0 & 20.8 & $20.1 \mathrm{~b}$ & $37.7 \mathrm{~b}$ \\
\hline
\end{tabular}

${ }^{a}$ For the treatments with residue (no residue harvested), the product was harvested, and the crop residue was left on the ground, including whole forage that was left in the field (oat-vetch and forage crops with residue). In treatments without residue (residue harvested), the product was harvested and the remaining residue was removed from the plots. For the oat-vetch, forage was cut and removed from the plot for animal feeding. For barley, the whole plant was cut and removed for threshing. The faba bean crop was harvested and the residue was left in the field. Finally, in the case of pasture, forage was cut on all parcels and withdrawn for animal feeding.

${ }^{\mathrm{b}}$ Within a column for a given watershed (crop residue harvesting vs no crop residue harvesting), numbers with different letters are significantly different (LSD) at $P \leq 0.05$.

${ }^{c}$ Barrera et al. (2019).

forage systems of oat/vetch with conservation agriculture could provide an advantage to 200,000 farmers in this region.

Barrera et al. (2019) conducted a 4-year study to assess the effects of water deviation ditches, reduced tillage, residue retention, and application of 
$\mathrm{N}$ and economic returns in the Andean region of Ecuador. They found for these Andean highlands that conservation agriculture increases crop productivity and net economic benefits by as much as $25 \%$ and $24 \%$, respectively, when compared to the conventional practices. $\mathrm{N}$ fertilizer increased yields in fertilized barley (Hordeum vulgare L.) and pasture crops. There was no significant difference between faba beans (Vicia faba L.) that were not fertilized but were planted following the fertilized barley plots, vs faba beans that were not fertilized and were planted after non-fertilized barley plots.

Leaving crop residue at the site had a significant positive impact. Leaving potato residue increased the yields of oat/vetch and leaving barley residue increased the yields of faba beans, but yields of barley were not affected by leaving oat/vetch residue, and pasture residue was not affected by leaving faba bean residue. Although the yields with water deviation ditches were higher, they were not significantly different if the ditches were not installed. The study was monitored for just 4 years, which was not long enough to observe an effect from the water deviation ditches on erosion. We proposed that in order to see effects in these no-till and cultivated systems, a longer period of using water deviation ditches at this site may be needed, especially since some of the crops in the rotation were cover crops such as oat/vetch and pasture and a small-grain barley that also has a significant amount of cover and residue.

The data suggested that the residue of the oat/vetch did not contribute enough $\mathrm{N}$ to the barley since the barely yields were not significantly different with oat/vetch residue vs no oat/vetch residue, and the barley grain responded to a $\mathrm{N}$ fertilizer application of $50 \mathrm{kgNha}^{-1}$. These studies by Barrera et al. (2019) were conducted at the Illagama River watershed, which has an elevation ranging from 2500 and $4500 \mathrm{~m}$ above sea level. The average temperatures for site ranged from $10.3^{\circ} \mathrm{C}$ to $13.8^{\circ} \mathrm{C}$. Conservation studies were conducted by Delgado et al. (2019) with a oat/vetch cover crop at the Rio Alumbre micro-watershed at a lower altitude ranging from 1800 to $2500 \mathrm{~m}$, with a warmer average temperature ranging from $15^{\circ} \mathrm{C}$ to $19^{\circ}$ C. Delgado et al. (2019) studied the effect of $\mathrm{N}$ fertilizer and no $\mathrm{N}$ fertilizer. Delgado et al. (2019) found that the first $\mathrm{N}$-fertilized study with corn responded to an application of $80 \mathrm{kgNha}^{-1}$ with higher corn grain production in the fertilized plots than the non-fertilized plots, even though they were planted after the oat/vetch crop. In contrast, the second corn grain did not respond to the $80 \mathrm{~kg} \mathrm{Nha}^{-1}$, and grain yields from fertilized and non-fertilized corn were not significantly different, suggesting that the oat/vetch crop residue aboveground and belowground supplied enough 
$\mathrm{N}$ to the corn at an equivalent rate of $80 \mathrm{kgNha}^{-1}$. We propose that this response to the cover crop oat/vetch, suggests that at the lower altitude and warmer climate the mineralization of the oat/vetch residue could potentially provide enough $\mathrm{N}$, equivalent to the $80 \mathrm{kgNha}^{-1}$ fertilizer application.

Studies conducted by Barrera et al. (2019) in the Illangama watershed found that $\mathrm{N}$ fertilizer increases economic returns by 659 US dollars ha ${ }^{-1}$ $(P<0.05)$. They also found that the net income of the no-residue-harvested plots (plots with residue returned to the plots) was higher than the residueharvested plots by about 200 US dollars ha ${ }^{-1}$, but this higher net income was not significantly different. Reduced tillage increased the economic returns by 425 US dollars ha ${ }^{-1}(P<0.05)$. There is potential to implement conservation agriculture, including the use of cover crops in combination with no-till, crop residue management and $\mathrm{N}$ fertilizer, and potentially increase the net income of farmers in the region.

\subsection{New cover crop studies in the Andean region}

We started similar conservation agriculture studies in two additional watersheds of the Andean region and monitored the crop rotations described in Table 1 from 2015 to 2019 in the Sicalpa watershed, ranging from 3000 to $4000 \mathrm{~m}$ in elevation, and also in the Paute watershed, ranging from 2500 to $3500 \mathrm{~m}$ in elevation. The crop rotations are described in Table 1. For detailed methods on how the crop residues were handled and the yields were collected, see Delgado et al. (2019) and Barrera et al. (2019). The different management practices studied at these sites are described in Table 1. For this paper we only presented the published data from the Illangama site (Barrera et al., 2019) and the new unpublished data from crop residue management at the Sicalpa and Paute watersheds.

At Sicalpa there was a significant increase in yields in oat/vetch, barley, faba bean, oat/vetch, potato, and forage by leaving the crop residue at the plots (Table 2). It was clear that leaving the system covered had improved either chemical, physical or biological properties at these sites. Unfortunately, due to the distance to the laboratory and where these plots were established, these properties were not monitored. We suggest that cycling of the $\mathrm{N}$ from leguminous crops was not the only function driving these higher yields since crops following non-legumes also had higher yields. Thus, either nutrient cycling (other than cycling of $\mathrm{N}$ ), water balance due to reduced evapotranspiration of a covered mulched soil, or other positive 
impacts on soil biology may have contributed to the higher yields in plots with crop residue, since six of six crops had higher yields. Cover crops significantly increased yields in this Andean watershed $(P<0.5)$.

The effects of crop residue at the Pauta watershed were different, however. Harvesting of residue did not affect the yields during the first 2 years from 2016 to 2017, but in the long term, the yields of the plots with crop residue in 2018 and 2019 had higher yields when the residue was not harvested than when the residue was harvested (Table 2). This suggests that the response in this site was not directly related to $\mathrm{N}$, and may be related to a longer response from the soil, that could also be an improvement in nutrient availability at the surface soil or other biological and/or physical responses to recycling higher levels of SOM. These studies at the Pauta and Sicalpa watersheds show that cover crops can potentially benefit cropping systems of the Andes by increasing N cycling (Illangama) and having long-term positive effects on soils. Keeping the soil covered and adding and recycling large amounts of $\mathrm{C}$ back into the soil generates conditions in the Andean region that contribute to higher yields.

The cost analysis of cover crops and leaving residue at these three watersheds (Illangama, Paute and Sicalpa; Table 3) show higher net economic

Table 3 Effect of crop residue management ${ }^{a}$ on average gross and net income and average cost for the different crops, including cover crops grown in the Illangama, Sicalpa and Paute watersheds in Andean regions of Ecuador ${ }^{\mathrm{b}}$.

\begin{tabular}{|c|c|c|c|c|c|c|c|c|c|}
\hline \multirow[b]{3}{*}{ Treatment } & $\begin{array}{r}\text { Illa } \\
\text { wat }\end{array}$ & $\begin{array}{l}\text { ingan } \\
\text { ersh }\end{array}$ & & \multicolumn{3}{|c|}{ Sicalpa watershed } & \multicolumn{3}{|c|}{ Paute watershed } \\
\hline & \multicolumn{9}{|c|}{ (thousands USD ha $^{-1}$ ) } \\
\hline & GI & $\mathrm{TC}$ & $\mathrm{NI}$ & GI & $\mathrm{TC}$ & NI & GI & $\mathrm{TC}$ & NI \\
\hline $\begin{array}{l}\text { No residue } \\
\text { harvested }\end{array}$ & $11.1 \mathrm{a}$ & 5.0 & $6.1 \mathrm{a}$ & $23.0 \mathrm{a}$ & $10.1 \mathrm{~b}$ & $12.9 \mathrm{a}$ & $27.5 \mathrm{a}$ & 10.5 & $17.0 \mathrm{a}$ \\
\hline $\begin{array}{l}\text { Residue } \\
\text { harvested }\end{array}$ & $10.1 \mathrm{~b}$ & 5.0 & $5.0 \mathrm{~b}$ & $21.6 \mathrm{~b}$ & $10.4 \mathrm{a}$ & $11.2 \mathrm{~b}$ & $24.9 \mathrm{~b}$ & 10.8 & $14.1 \mathrm{~b}$ \\
\hline
\end{tabular}

${ }^{\mathrm{a}}$ For the treatments with residue (no residue harvested), the product was harvested, and the crop residue was left on the ground, including whole forage that was left in the field (oat-vetch and forage crops with residue). In treatments without residue (residue harvested), the product was harvested and the remaining residue was removed from the plots. For the oat-vetch, forage was cut and removed from the plot for animal feeding. For barley, the whole plant was cut and removed for threshing. The faba bean crop was harvested and the residue was left in the field. Finally, in the case of pasture, forage was cut on all parcels and withdrawn for animal feeding.

${ }^{b}$ Within a column for a given watershed (crop residue harvesting vs no crop residue harvesting), numbers with different letters are significantly different (LSD) at $P \leq 0.05$.

${ }^{c}$ Barrera et al., 2019.

GI, gross income; TC, total cost; NI, net income. 
returns. The results from Delgado et al. (2019) in the Rio Alumbre also showed benefits, as discussed previously. However, the benefits of using cover crops as described by Delgado et al. (2019) and Barrera et al. (2019) also prove that there are other benefits if the farmers use $\mathrm{N}$ fertilizer to increase yields, use no-till and deviation ditches, and add cover crops to the rotations. Studies conducted in four different watersheds found that leaving the crop residue on the plots contributes to higher yields. The effects of the crop residue are more significant in watersheds such as Sicalpa where crop residue increased yields immediately and four crops grown constantly over 3 years. In other watersheds the effects of the crop residue took a longer time to impact agricultural productivity, not having an immediate effect in the first and second years, but increasing yields after leaving the crop residue for a third year in watersheds like Rio Alumbre and Rio Pauta.

One analysis that was not conducted in these studies was an assessment of the economic benefits at the whole-farm level for these small farms. We did not assess what benefits there may be if the farmers use their produced aboveground forage hay from oats/vetch and forage to feed the animals vs leaving the forage hay at the farm. Most farmers have an animal at their farms; a horse, a cow, or other animal that may use the forage. For example, Delgado et al. (2019) found that the most economically beneficial approach was when forage was harvested since the forage has an economic value. Additionally, improved forages like oats/vetch may increase the protein quality of the forage, potentially increasing milk production, but these factors were not studied.

The studies conducted in this case scenario from Ecuador, from the previous studies by Delgado et al. (2019) and Barrera et al. (2019), to the new data presented here, show that there is potential to use cover crops with no-till, $\mathrm{N}$ fertilizer, water deviation ditches and other conservation practices to increase economic benefits for farmers. Unfortunately, all the potential ecosystem services of these practices have not been assessed in terms of what will be the total potential of these farmers to get a payment for incorporation of the crop residue. Additional research measuring the impacts on soil $\mathrm{C}$ sequestration and nutrient cycling from these practices are needed, as well as assessment of greenhouse gas emissions from these systems and the potential for ecosystem services to be sold in future ecosystem markets. These studies show that additional research studies are needed in this region that measure more intensively the changes in chemical and physical properties due to the use of cover crops. However, there are potential immediate positive responses from conservation agriculture, including positive effects on 
yields and economic returns, and there is potential to use these practices to adapt to a changing climate by increasing the sustainability of these systems.

\subsection{Economic benefits of cover crops}

In the steep slopes of the Andes in central Ecuador, the use of cover crops can provide several economic benefits while reducing negative environmental externalities. These economic benefits will accrue in the form of costs savings, as cover crops use is primarily related to a potential reduction in the application of fertilizers, herbicides, and pesticides as well as mechanical operations. These benefits will have a direct impact on farm profits. Society will also benefit as cover crops can help increase SOM, reduce soil erosion and achieve sustainability, the monetary value of which is difficult to evaluate. Although these potential benefits sound promising, it should be noted that they do not necessarily indicate a positive causal impact of cover crops on farm profitability, as it may be that farmers with higher incomes are more likely to adopt cover crops (Bergtold et al., 2017).

\subsection{Opportunity costs}

While Andean Andisols store large amounts of C, tillage practices used to plant potatoes on steep slopes have disrupted soil structures and left soils exposed to wind and rain erosion, which imposes additional costs to farmers and society. On the farm, soil health degradation and erosion of productive soils, both associated with conventional tillage (e.g., without groundcover), lower the productive potential of the land (Delgado et al., 2019; Quintero and Comerford, 2013). Although these are real costs incurred by the farmer, they may become evident only after a long gestation period, or may be unobserved by the farmer during year-to-year farming operations (Alwang and Sowell, 2010; Barrowclough and Alwang, 2017). Off the farm, costs are felt by others; release of organic matter stored in soil contributes to atmospheric $\mathrm{C}$ loading and soil erosion leads to steep economic costs to society due to siltation-related flooding in the Guayas watershed, the largest and most economically important in western Ecuador (Harden, 1993).

\subsection{Policy implications}

Policies in Ecuador aimed at increasing the use of cover crops in this country should focus on the economic barriers to their adoption. These include: (i) relatively slow crop response to enhanced soil health (Barrowclough and Alwang, 2017); (ii) high costs of herbicides which are needed to 
terminate the cover crop (Bergtold et al., 2017); (iii) lack of soil moisture during the cover crop establishment period; and (iv) economic competition with use of cover crops for livestock feed. Moreover, the relatively poor farmers who grow potatoes in steep slopes of the Andes in central Ecuador may heavily discount the future or be unaware of the long-term benefits of maintaining soil cover.

In addition, institutional mechanisms in Ecuador should focus on transmitting to farmers the costs of erosion (Echeverría, 2002a,b), as well as helping them capture any of the benefits to cover crop use from reducing damages. At the end of the day, without cost-share mechanisms such as those that exist in the U.S. and other developed countries, the decision to use cover crops is one farmers make based on an economic calculus of costs and benefits to themselves. While relatively modest positive returns have been found from use of cover crops (Delgado et al., 2019) and the economic margins are razor-thin, they have not had a negative economic impact.

However, if we consider what will be the final effects of the business-asusual practices of traditional agriculture that disturb the soils, productivity significantly declines with the loss of surface soils due to erosion. When research plots are established in already-degraded systems, it is difficult to assess what the productivity was decades earlier, when the soils surface soils were deeper. Since there are no long-term research plots that are being monitored over 20 or 30 years, it is difficult to assess the long-term effects of traditional, business-as-usual practices. Recent studies have shown that these cover crops will maintain productivity and sustainability without economic losses, or even with positive economic returns, albeit razor-thin (Barrera et al., 2019; Delgado et al., 2019).

The Delgado et al. (2019) long-term research data (4 years) suggest that cover crops and conservation agriculture can contribute to increased potential yields and net economic returns across high-altitude systems in the Andean region of Ecuador (Tables 1-3; Delgado et al., 2019; Barrera et al., 2019). In three different watersheds, we found that yields of potato and/or corn were increased by $25 \%$ or more after $2-4$ years of implementing conservation agriculture with cover crops. Although these results were found in relatively long-term research (4 years), there is a need to conduct studies over longer periods, such as a decade or two decades, to see the effects of multiple rotations and how they may affect yields and potentially contribute to climate change adaptation. 


\section{Cover crops for climate change adaptation}

Changing global climate is a reality, and it is impacting cropping systems throughout the world. One key question is how cropping systems are going to adapt to these changes, which could not only impact crop productivity, but also impact soil and water quality as well as soil health. Implementation of conservation practices, including the use of cover crops, is going to be key across agricultural systems to adapt to a changing climate. The benefits of using cover crops are numerous; they can be used to improve the soil structure to improve water retention by soils; they can also improve drainage; and they can protect against wind and water forces that contribute to erosion, which is especially important in instances of extreme events, where the energy of these forces increases, contributing to higher potential erosion rates (Delgado et al., 2011; Walthall et al., 2012). In order to adapt to a changing climate that has been projected will increase the occurrence of extreme events, use of conservation practices will be essential, and cover crops are a key tool in the toolbox to adapt to a changing climate.

The following are potential ways cover crops can contribute to climate change adaptation. The potential for cover crops to serve as a tool for climate change adaptation via each of the following categories is ranked along a scale of + to +++++ , from a positive impact that is minimally likely to contribute to climate change adaptation $(+)$, to something that is very likely to contribute to climate change adaptation $(+++++)$. In other words, the rankings of the positive impacts for climate change adaptation were as follows: Very high $(\mathrm{VH}),+++++$; High $(\mathrm{H}),++++$; Medium $(\mathrm{M}),+++$; Low $(\mathrm{L}),++$; Very low $(\mathrm{VL}),+$.

\subsection{Potential of cover crop impacts to contribute to climate change adaptation}

Cover crops can:

1. Contribute to reduced surface erosion, protecting soil health and productivity: $\mathrm{VH},+++++$

2. Contribute to reduced wind erosion: $\mathrm{H},++++$

3. Contribute surface residue that will protect the soil: $\mathrm{VH},+++++$

4. Contribute to increased synergism among conservation practices such as using cover crops with no-till, or using cover crops with residue management by leaving residue behind to protect soil surfaces, or using 
cover crops in buffers and riparian zones, which will increase the effectiveness of conservation efforts: $\mathrm{VH},+++++$

5. Be used with precision conservation to target those areas of the fields that, due to spatial and temporal variability, will be more affected by a changing climate, especially via extreme weather events. Cover crops could be used with precision conservation to target the most risky landscape-cropping system combinations to increase the effectiveness of conservation practices at these hot spots in the field and outside of the field (e.g., buffer areas, riparian zones, and other areas): $\mathrm{VH},+++++$

6. Contribute to cycling of $\mathrm{N}$ to the subsequent crop, increasing yields: $\mathrm{VH},+++++$

7. Contribute to cycling of other nutrients to the subsequent crop, increasing yields: $\mathrm{H},++++$

8. Contribute to production of forage for animals: $\mathrm{VH}(+++++)$ for humid, sub-humid, and irrigated tropical systems; $\mathrm{VH}(+++++)$, and $\mathrm{M}(+++)$ for arid and semiarid tropical systems

9. Contribute to improved soil health: $\mathrm{VH},+++++$

10. Contribute to improved soil function, biogeochemical cycles, and soil biology, adding organic matter and providing other benefits needed for climate change adaptation: $\mathrm{VH}(+++++)$

11. Contribute to improved diversity in the crop rotations, which could have a positive effect on soil biology and beneficial insects: $\mathrm{VH}(+++++)$

12. Be used with off-the field conservation practices, protecting the environment, for precision conservation to reduce water flows across the farm and to enhance wildlife in buffers and riparian areas that contribute to climate change adaptation and mitigation: $\mathrm{VH}(+++++)$

13. Contribute to reduced runoff, which could increase the storage of water in the soil profile: $\mathrm{H}, \mathrm{VH}(++++)$

14. Increase availability of water for the next crop: $M(+++)$ for humid systems and arid and semiarid systems if the cover crop is managed with agrochemicals and is killed before the cover crop decreases the water in the soil profile, potentially impacting the subsequent crop; VL (+) for arid and semiarid systems if the cover crop uses the water stored in the soil before the next crop, potentially reducing the yields of the subsequent crop in these arid and semiarid systems

15. Contribute to reduced evapotranspiration in the subsequent crop: $\mathrm{H}(++++)$ if used as mulch 
16. Contribute to increased water storage capacity of the soil: $L(++)$ for cultivated tillage systems; $\mathrm{H}(++++)$ for no-till and minimum tillage systems

17. Contribute to weed control: $\mathrm{M}(+++)$

18. Contribute to control of pathogens: $\mathrm{L}(++)$

19. Contribute to nematode control: $\mathrm{H}(++++)$

20. Potentially protect surface water quality: $\mathrm{VH}(+++++)$

21. Potentially protect groundwater quality: $\mathrm{VH}(+++++)$

22. Potentially increase crop quality and to contribute higher quality nutrition in crops or forages, potentially improving human or animal health: $(\mathrm{H}++++)$

23. Potentially contribute to higher net incomes: $\mathrm{H}(++++)$ if crop residues are harvested or grassed; $\mathrm{M}(+++)$ or $\mathrm{L}(++)$ if crop residues are not harvested

24. Potentially contribute to long-term sustainability of cropping systems: $\mathrm{VH}(+++++)$

25. Potentially contribute to long-term sustainable systems that will maintain higher productivity and higher net incomes: On a long term basis, $\mathrm{VH}(+++++)$ if crop residues are harvested or grazed, $\mathrm{M}(+++)$ to $\mathrm{H}(++++)$ if crop residues are not harvested

26. Potentially contribute to reduced net greenhouse gas emissions if using right cover crops at the site; $\mathrm{H}(++++)$

27. Potentially contribute to higher $\mathrm{C}$ sequestration: $\mathrm{H}(++++)$ for no-till and conservation agriculture, $\mathrm{L}(++)$ for cultivated tillage systems

It is important to use cover crops to adapt to a changing climate considering the $4 \mathrm{Rs}$ of cover crops. Cover crops should be used at each site considering the spatial and temporal variability of a given site across the tropics to increase the potential for positive economic impacts as well as greater environmental protection and improved soil and water conservation. When using cover crops across the tropics, agronomists, nutrient managers, ecologists, farm managers and other users should consider using the 4 Rs of managing cover crops by using the right cover crop, the right timing of placement, the right timing of killing, and the right management at each tropical site (Delgado and Gantzer, 2015).

There is a vast amount of information available about the use and management of cover crops across the tropics. This chapter has reviewed a large number of success stories, as well as other studies where there have been failures when using cover crops. Cover crops are not a silver bullet that will be successful at each site. It is important to use the $4 \mathrm{R}$ s of cover crops (the right 
cover crop, the right timing of placement, the right timing of killing, and the right management) at each tropical site. Cover crops are a management tool that are most beneficial when used together with fertilizer application to the subsequent crop. Nitrogen is particularly important because the majority of tropical soil systems are deficient in this nutrient.

There is a large body of literature showing that the benefits of cover crops are amplified when used with $\mathrm{N}$ fertilizer applications. Yet there are still a large number of research gaps, and additional research will be needed in order to fully take advantage of these key tools for climate change adaptation. The art and science of using cover crops will benefit from additional research to provide the information needed to make better decisions on how to use cover crops across the tropics. The following section presents some of the research gaps with respect to cover crops. While it is not intended to be an exhaustive or all-inclusive list of every important research gap in this area, it identifies a few areas of research that would definitely contribute to improving the body of knowledge needed to make decisions of when, where and how to use cover crops across the tropics.

\section{Research gaps}

There is enormous potential to use cover crops across the tropics. These crops can be used as nutrient and cropping system management tools to increase yields and/or improve soil and water conservation and sustainability. They can be used to improve the health of tropical soil, by improving biological, chemical and physical soil properties that could contribute to increased nutrient cycling and higher water availability as well as improved infiltration. In general, cover crops could be used to increase crop yields and crop quality, which could have positive impacts on animal and human health. With that said, cover crops are not a panacea and if the wrong cover crop is used, or the cover crops are not managed correctly for the sitespecific conditions, this could contribute to a yield hit in the subsequent crop. Furthermore, if the wrong cover crop and/or the wrong management practices are used, this could contribute to increased weeds, reduced water availability for the subsequent crop, and/or other negative impacts. Still, with the right management and the right cover crop planted and killed at the right time, cover crops can contribute to increased yields; improved crop quality, which could potentially have positive impacts on human and animal health; forages with higher protein content, which could help increase the 
productivity of the livestock; and improved soil health, soil and water conservation and sustainability of tropical systems.

There are many research gaps that need to be filled. The following list does not include all of the research gaps but provides the reader with a sense of key research that is needed across the tropics to improve our knowledge about how to use cover crops and transfer the needed information to farmers and ranchers across tropical regions. Challenges related to social factors include the question of how to increase dissemination of the needed information to use the right cover crops. A better understanding is needed of what factors are driving the decisions of farmers across the tropics to use or not use cover crops. There are also economic questions such as the potential viability of ecosystem markets that could contribute to payments to farmers for implementing conservation practices, such as what is available in some temperate areas. There is a need for extension services across the tropics to help disseminate information to farmers and ranchers. There is also a lack of soil and water conservation support programs that may help farmers apply these practices. Following are some of the research gaps.

\subsection{List of research gaps}

1. Since there is, to the best of our knowledge, a lack of long-term cover crop research plots in the tropics that are being monitored over 20 or 30 years where the long-term effects of erosion on high slopes have been monitored, it is difficult to assess the long-term effects of traditional, business-as-usual practices vs long-term use of cover crops in tropical areas. There is a need for long-term research studies about use of cover crops to assess how $\mathrm{N}$ and other nutrient cycling is affected, as well as SOM, C sequestration, greenhouse gas emissions, and impacts on yield of subsequent crops after two or three decades.

2. Research gap \# 1 needs to consider regional crops as well as highaltitude systems of the tropics vs medium- and low-altitude cropping systems.

3. Research gaps \#1 and \#2 need to consider humid as well as semiarid and arid systems.

4. Although long-term cover crop research is needed, short-term cover crop research that could contribute to transfer of conservation practices using cover crops that accounts for differences in regions, weather, soil type, tillage management and effects on soil $\mathrm{C}$ sequestration, nutrient cycling, greenhouse gas emissions, yields and economic returns, is also needed. 
5. There is a need for an open-access data information system about cover crops in the tropics where research data is uploaded.

6. There is a need for software tools to help implement the right cover crops, at the right time, and to help plant and kill the cover crop at the right times, and to help identify how to handle spatial and temporal variability when using cover crops.

7. Research on advanced models (improvement of current models and development of new models as needed), machine learning, and artificial intelligence systems for better application of cover crops across the tropics is also needed.

8. There is a need for additional research about how to use cover crop management to reduce erosion while minimizing the negative impacts on yields of trees (e.g., coffee).

9. Additional social research is needed on perceptions of the use of cover crops in the tropics.

10. Additional research is needed on the potential use of cover crops for human and animal feed, and its potential impacts on human and animal health.

11. Additional research is needed to improve our understanding of the interactions of weather, rotations, soil type and other parameters and their effects on cover crops and yields of the subsequent crops in the tropics.

12. There is a need for additional research on how social aspects and limited markets and credits impact the potential to use cover crops under degraded tropical soils.

13. There is a need to improve understanding of how the use of cover crops impacts fauna and soil biology in the tropics.

14. Additional research that considers local, already adopted tropical cover crops and their potential to be used in other tropical regions, is also needed.

15. Research on how to make viable recommendations to farmers in degraded tropical soils to optimize the crop water productivity in low-fertility soils is needed.

16. There is a need for research on how cover crops could be used under extreme drought conditions. There is a need to expand the portfolio of options for local farmers and to conduct research on the minor indigenous legumes that are currently being used and that have already been shown to be adapted to drought events that occurred across these semiarid and arid tropical regions. 
17. Additional research on how to use cover crops to suppress and/or control weeds, nematodes and soil pathogens across the tropics is needed.

\section{Summary}

Soil productivity will be one of the most important environmental factors (perhaps even the most important factor) for ensuring the survival of humanity during the 21st century. This key factor will likely be more important than ever before as the expanding global human population faces the unprecedented challenges of a rapidly changing climate. More than ever, it is of critical importance to conserve the world's soil resources so that the needed increases in agricultural production to feed $9-10$ billion people can be achieved.

Soil resources are so important for a myriad of reasons. It has been reported that most of the productive agricultural land is already in cultivation. Another challenge that is impacting agricultural land is desertification, which is increased by poor land management practices such as deforestation, overgrazing, improper irrigation practices, over-cropping or other factors where soil health and soil biology is significantly impacted, and soils are degraded. Salinization also affects cultivated areas when salts are built up to levels that are harmful to crops and reduce productivity, or when saline water is used for irrigation. Improper management of water resources could also contribute to salinization of aquifers, which could negatively impact irrigated areas. Urban sprawl will also have an adverse impact on global agricultural productivity levels, as on average, land used for development tends to be highly productive land, and it is no longer available for agricultural use when diverted to urban development.

Another challenge is water scarcity. Aquifers are being depleted worldwide, from the USA (Ogallala Aquifer), to Mexico, to the North China Plain and elsewhere, and in some regions snow caps are being impacted by climate change with lower snow accumulation. Urban expansion and global human population also require water resources that are used by agriculture. All of this exacerbates overall water scarcity, and translates to reduced water availability for irrigation-and irrigated land produces on average, two or three times that of non-irrigated land, especially in arid and semiarid regions. These are just a few examples of the challenges humanity faces with respect to increasing global agricultural production. Although yields may increase in some regions with climate change because of a warmer climate, there are other factors that influence crop productivity, such as the 
increases in evapotranspiration as climatic changes increase average temperatures, and the higher potential loss of soil productivity due to erosion if precipitation events increase and no conservation practices are implemented.

Finally, there is the challenge of a changing climate, which poses a severe threat to soil productivity and efforts to increase soil productivity to meet the increased food demand that accompanies a global population expected to grow by several billion more people in the next 30 years. The earth's already-changing climate and the increased occurrence and intensity of extreme events are among the greatest threats to soil health and soil productivity. The potential for increased erosion due to higher precipitation events (i.e., water erosion) or extreme droughts (i.e., wind erosion) caused by climate change is significant, and erosion can compromise soil health and reduce soil productivity. It has been reported that soil productivity gets reduced by $4-30 \%$ per every $10 \mathrm{~cm}$ of soil lost, and that the loss of productivity from the next $10 \mathrm{~cm}$ of soils that is then lost, will be much higher since the most productive and healthy soils are at the surface (Bakker et al., 2004). On average, soil productivity is reduced with depth, since the lower soil layers have lower soil organic matter and nutrient content.

Soil management during the 21st century will be key for the survival of humanity. Conservation practices, including the use of cover crops, will be a critical and societies that do not implement conservation practices across the tropics or even temperate or sub-tropical regions will be negatively impacted (Fig. 6). Policies for soil and water conservation and climate change adaptation will be essential if societies are to have an opportunity to adapt to a changing climate while maintaining food security (Fig. 1). Professional societies such as the Soil and Water Conservation Society (SWCS) and World Association of Soil and Water Conservation (WASWAC) have adopted position statements that state conservation practices for climate change adaptation are necessary, including the use of cover crops.

One of the key management practices and tools available for climate change adaptation across the tropics will be cover crops. We could use cover crops across the tropics to protect the soil surface and reduce erosion, improve soil health, and contribute to carbon sequestration, which will improve soil biological functions and cycle essential nutrients to increase yields. Cover crops can be used to increase yields across tropical areas in Africa, Asia, Latin America, Australia and other regions. Cover crops can also contribute large quantities of nitrogen fertilizer equivalent, especially when leguminous cover crops are used to fix atmospheric nitrogen and cycle nitrogen to the next crop, on occasion up to $300 \mathrm{~kg} \mathrm{Nha}^{-1}$. A large number 


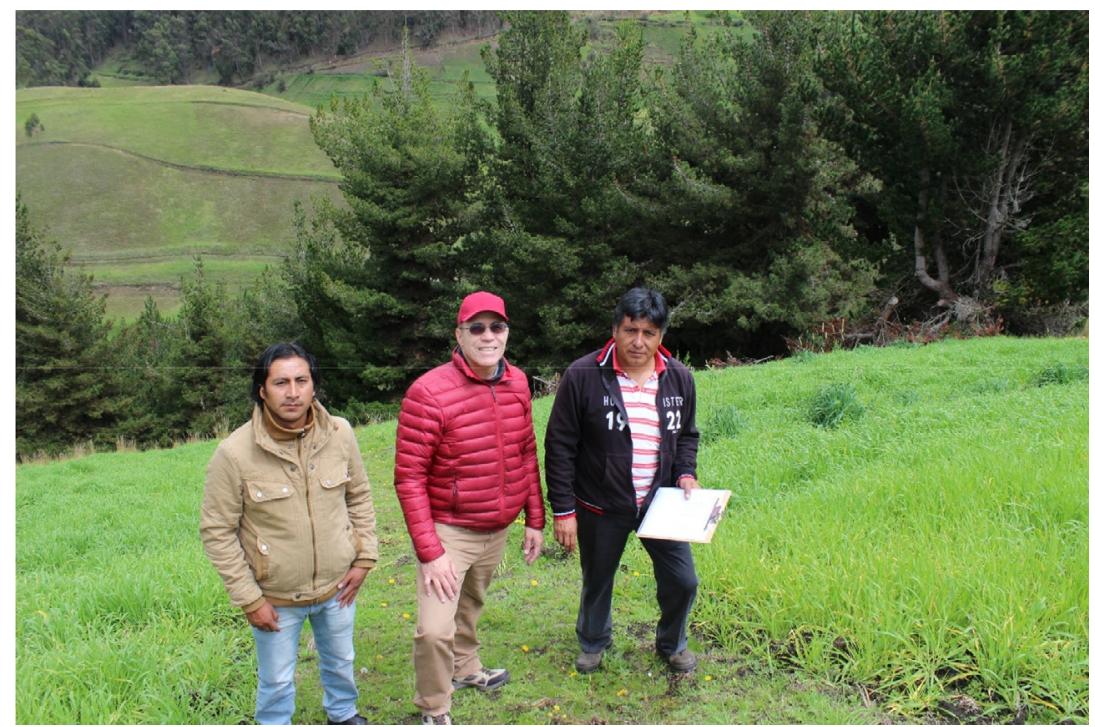

Fig. 6 Improved use of cover crops with conservation agriculture in high slope areas of Ecuador where they can contribute to reduced erosion. Note: Photo by Yamil Cartagena, INIAP.

of other macro- and micro-nutrients are also cycled to the next crop, improving the nutritional value and protein content of the subsequent crop, which could potentially have significant positive impacts on human and animal nutrition.

Cover crops could potentially be used across the tropics to increase the soil health of these systems, and on occasion, could even increase the soil health of low-quality, degraded tropical systems, which could respond significantly to the improvement in soil biological functions and nutrient cycling to the subsequent crop resulting from cover crop use. Such improvements in soil biological functions and soil biology would make the soils more resilient and improve their ability to adapt to a changing climate. Although in some cases tropical grain production following cover crops without $\mathrm{N}$ fertilizer could achieve similar grain yields to those achieved with applied $\mathrm{N}$ fertilizer alone, responses across all tropical regions tended to be higher with grains such as corn that were grown after a leguminous cover crop with additional nitrogen fertilizer applied to the grain crop. On occasion, a mixture of tropical leguminous and non-leguminous cover crops, or even a nonleguminous cover crop, such as a grass, could also contribute to significantly higher yields when the grain crop is supplemented with nitrogen fertilizer. 
With that said, it must be noted that on occasion cover crops could contribute to lower yields, and this is especially the case in arid and semiarid systems when growing the cover crop also requires the use of valuable water that the subsequent crop could have used to produce higher yields. However, intensification of fallow systems with cover crops has been reported to work in some instances, if implemented with conservation agriculture (no-till/minimum tillage) and use of mulch systems that could reduce evapotranspiration in the next cropping system. In cropping systems throughout the world, but particularly in arid and semiarid systems, the management of cover crops necessitates the use of the 4 Rs of cover crops. The 4 Rs of cover crops should be applied when using this tool (the right cover crop, the right timing of placement, the right timing of killing, and the right management).

Conservation agriculture with cover crops could have an immediate positive impact on the yields of the next crop in some cases. Sometimes it takes 2 or 3 years to increase the yields with significant nitrogen fertilizer equivalency. Although there is an extensive body of literature about productivity responses to cover crops across the tropics, there is a need for additional research, especially since there are so many combinations of cropping systems (e.g., forages, trees, vegetables), soil types, weather, and high and low elevations across the tropics. When using cover crops, decisions regarding how to manage weeds, diseases, and pests (i.e., nematodes) are also important and should be considered, as well as the potential to use cover crops for grazing. Cover crop management decisions will need to integrate a large amount of information. There are large research gaps that still need to be addressed across the tropics, and the need for long-term research bears repeating.

Management decisions such as when to plant a cover crop and when to kill a cover crop can impact (positively or negatively) the yield of the subsequent crop, so it is important to take site-specific conditions into consideration. Sometimes killing a cover crop earlier will increase the release and transfer of nutrients to the crop that follows, improving the synchronization between the release of the nutrients from the cover crop and the nutrient uptake demands of the subsequent crop. If the goal is to use the cover crop to increase carbon sequestration, then no-till or minimum tillage systems with mulching (crop residue returned/not harvesting aboveground stalks and leaves) could be a viable option. However, several scientists, working in either temperate (Figs. 7 and 8) or tropical regions have found that despite harvesting the aboveground residue (stalks and leaves), there are still 


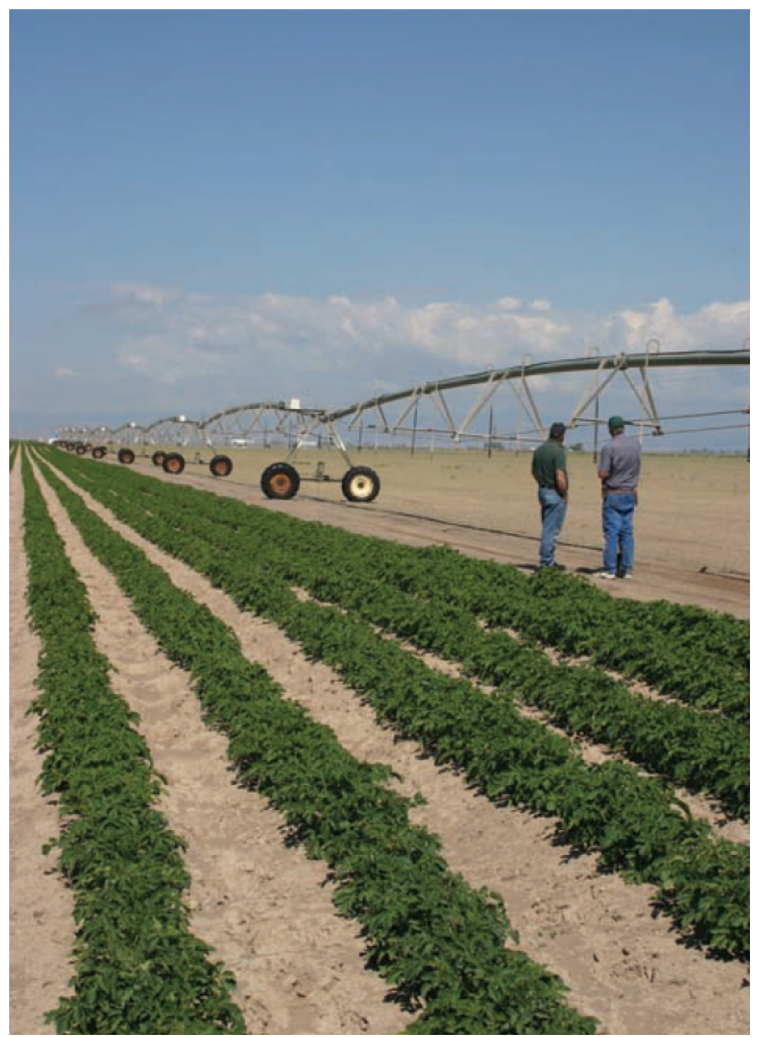

Fig. 7 Irrigated potatoes (left) and recently planted summer cover crop with limited irrigation (right). Note: Photo by Juan Herrera, formerly at the USDA Agricultural Research Service, now at the University of Buenos Aires, Argentina. From Delgado, J. A., Dillon, M. A., Sparks, R. T., and Essah, S. Y. C., 2007a. A decade of advances in cover crops: cover crops with limited irrigation can increase yields, crop quality, and nutrient and water use efficiencies while protecting the environment. J. Soil Water Conserv. 62 (5), 110A-117A.

potential increases in yields of the subsequent crops, suggesting that the biological effects on soil functions as well as nutrient cycling are still happening, and thus that the belowground materials and some of the leaf residue still have a positive impact on the soil health and crop responses of the subsequent crop.

Cover crops are tools that can be used for different purposes. In tropical systems that receive more nitrogen than needed, a non-leguminous cover crop can be used to protect surface and groundwater by acting as scavenger crops to recover the excess applied nitrogen from the soil profile. In areas where there are deficiencies in nitrogen applications and low rates of 


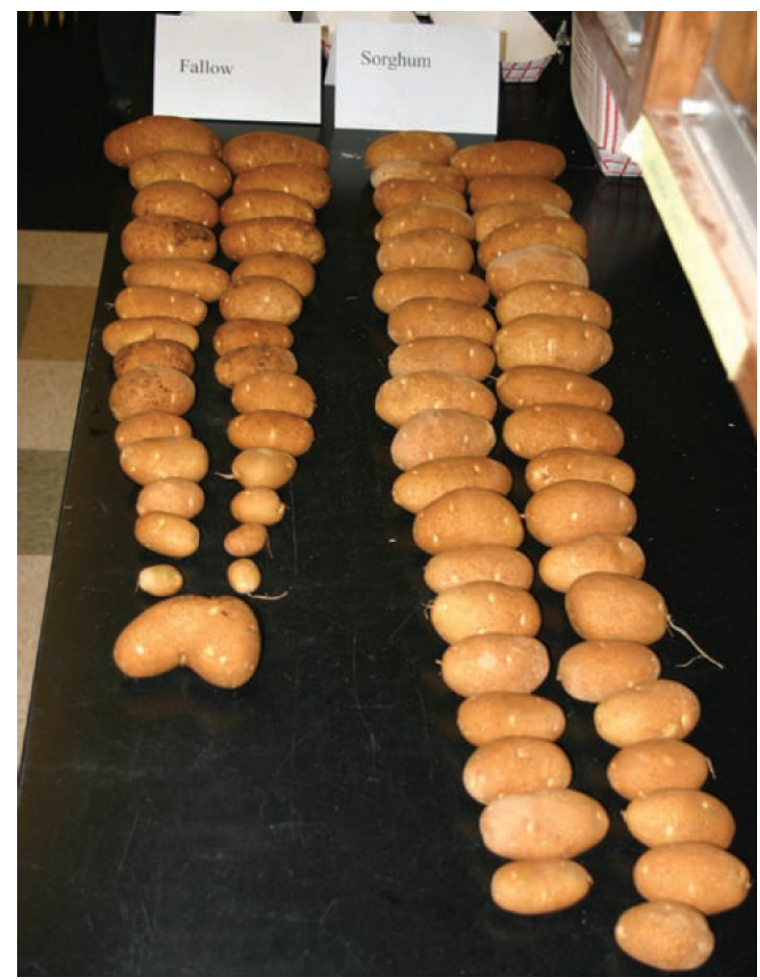

Fig. 8 The tuber production yield and quality for the potato following sorghum-sudan plots were significantly higher (tubers on the right side) than the production following a wet fallow plot (tubers on the left side). Note: Photo by Jorge A. Delgado, USDA Agricultural Research Service. From Delgado, J. A., Dillon, M. A., Sparks, R. T., and Essah, S. Y. C., 2007a. A decade of advances in cover crops: cover crops with limited irrigation can increase yields, crop quality, and nutrient and water use efficiencies while protecting the environment. J. Soil Water Conserv. 62 (5), 110A-117A.

nitrogen are being applied, leguminous cover crops can be used to add significant amounts of nitrogen to the system that has low amounts of nitrogen to increase yields. Cover crops will be a key tool during the 21 st century for climate change adaptation across the tropics.

\section{Glossary}

(Atylosia scarabaeoides L. Benth). (a.k.a. Cajanus scarabaeoides (L.) Thouars) Bananas (Musa sp.) Barley (Hordeum vulgare L.) Basil (Ocimum basilicum) Bean (Phaseolus vulgaris) Black medic (Medicago lupulina L.) Black oat (Avena strigosa L.) Burgundy bean (Macroptilium bracteatum) Butterfly pea (Clitoria ternatea) Calopo (Calopogonium mucunoides) Canola (a.k.a rapeseed) (Brassica napus subsp. napus) Carabao grass (a.k.a. hilo grass) (Paspalum conjugatum sp.) Cassava (Manihot esculenta Crantz) Centro 
(a.k.a. butterfly pea) (Centrosema pubescens) Christmas bush (a.k.a. siam weed, devil weed, common floss flower) (Chromolaena odorata) Coconut (Cocos nucifera L.) Coffee (Coffea arabica L.) Congo grass (Brachiaria ruziziensis) Corn (Zea mays L.) Cowpeas (Vigna unguiculate L.) Crimson clover (Trifolium incarnatum L.) Cupuaçu (Theobroma grandiflorum Willd. (ex Spreng.) K. Schum) (Desmodium adscendens (Sw.) DCo (syn. Ovalifolium Guillemin \& Perrottet)) Dyer's woad (Isatis tinctoria L.) Eucalypt (Eucalyptus grancam and Eucalyptus urograndis) Faba bean (Vicia faba L.) (Glycine wightii) Guinea grass (a.k.a green panic grass) (Panicum maximum) Hairy vetch (Vicia villosa Roth) Kidney vetch (Anthyllis vulneraria L.) Lablab (Lablab purpureus) (a.k.a Dolichos lablab, Dolichos purpureus) Lablab (Lablab purpureus) cv. "Rongai" Lettuce (Lactuca sativa L.) Millet (Pennisetum glaucum) Molasses grass (Melinis minutiflora) Oat-white oat (Avena sativa L.) Palisadegrass ([Urochloa brizantha (Hochst. Ex A. Rich.) R.D. Webster] [syn. Brachiaria brizantha (Hochst. Ex A. Rich) Stapf]) Peachpalm (Bactris gasipaes Kunth) Peanuts (Arachis hypogaea L.) Pigeon peas (Cajanus cajan L.) Porcupine jointvetch (Aeschinomene histrix) Potato (Solanum tuberosum L.) Rapeseed (Brassica napus subsp. napus) Rattlepod (Crotalaria grahamiana Wight \& Arn) Rice (Oryza sativa) Root-knot nematode (Meloidogyne incognita) Rye (Secale cereal L.) Ryegrass (Lolium multiflorum Lam.) Sorghum sudangrass (Sorghum bicolor S. sudanense) Soybean (Glycine max (L.) Merr) (Stylosanthes guianensis) (Stylosanthes hamata) Sunn hemp (Crotalaria juncea) Switchgrass (Panicum virgatum L.) Tomato (Solanum lycopersicum L.) Triticale (a hybrid of wheat and rye; $\times$ Triticosecale) Tropical kudzu (Pueraria phaseoloides Roxb. Benth.) Turnip (Brassica rapa) Velvet bean (Mucuna pruriens) Vetch (Vicia villosa Roth) (a.k.a hairy Vetch) Viper's bugloss (Echium vulgare L.) Wheat (Triticum aestivum L.) White clover (Trifolium repens L.) White hoarypea (Tephrosia candida DC.) Witchweed (Striga spp.)

Note: The authors referred to Wikipedia as a resource for the scientific and common names for the many tropical cover crops discussed in this paper.

\section{References}

Abdul-Baki, A.A., Klassen, W., Bryan, H.H., Codallo, M., Hima, B., Wang, Q.R., Li, Y., Lu, Y., Handoo, Z., 2005. A biologically-based system for winter production of freshmarket tomatoes in south Florida. Proc. Fla. State Hortic. Soc. 118, 153-159.

Afandi, Manik, T.K., Rosadi, B., Utomo, M., Senge, M., Adaci, T., Oki, Y., 2002. Soil erosion under coffee trees with different weed managements in humid tropical hilly area of Lampung, South Sumatra, Indonesia. J. Jpn. Soc. Soil Phys. 91, 3-14.

Alsheikh, A., Delgado, J., Barbarick, K., Sparks, R., Dillon, M., Qian, Y., Cardon, G., 2005. Effects of potato-grain rotations on soil erosion, carbon dynamics and properties of rangeland sandy soils. Soil Tillage Res. 81, 227-238.

Álvarez-Berríos, N.L., Soto-Bayó, S., Holupchinski, E., Fain, S.J., Gould, W.A., 2018. Correlating drought conservation practices and drought vulnerability in a tropical agricultural system. Renewable Agric. Food Syst. 33, 279-291.

Alwang, J., Sowell, A., 2010. Socioeconomic factors affecting soil and water conservation in South America. In: Napier, T. (Ed.), Human Dimensions of Soil and Water Conservation. Nova Science Publishers, Hauppauge, New York, pp. 305-319.

Arbuckle, J.G., Roesch-McNally, G., 2015. Cover crop adoption in Iowa: the role of perceived practice characteristics. J. Soil Water Conserv. 70, 418-429. https://doi.org/ 10.2489/jswc.70.6.418. 
Ashworth, A.J., Allen, F.L., Keyser, P.D., Tyler, D.D., Saxton, A.M., Taylor, A.M., 2015. Switchgrass yield and stand dynamics from legume intercropping based on seeding rate and harvest management. J. Soil Water Conserv. 70, 374-384.

Baijukya, F.P., de Ridder, N., Giller, K.E., 2005. Managing legume cover crops and their residues to enhance productivity of degraded soils in the humid tropics: a case study in Bukoba District, Tanzania. Nutr. Cycl. Agroecosyst. 73, 75-87.

Bakker, M.M., Govers, G., Rounsevell, M.D.A., 2004. The crop productivity-erosion relationship: an analysis based on experimental work. Catena 57, 55-76.

Barrera, V., Alwang, J., Cruz, C., 2010. Experiencias en el manejo integrado de los recursos naturales en la subcuenca del río Chimbo, Ecuador. (In Spanish.) Editorial Abya Yala. INIAP-SANREM CRSP-SENACYT, Quito, Ecuador.

Barrera, V., Escudero, L., Alwang, J., Andrade, R., 2012. Integrated management of natural resources in the Ecuador Highlands. Agric. Sci. 3 (5), 768-779.

Barrera, V., Delgado, J., Alwang, J., Escudero, L., Cartagena, Y., Domínguez, J., D’Adamo, R., 2019. Conservation agriculture increases yields and economic returns of potato, forage, and grain systems of the Andes. Agron. J. 111, 2747-2753. https://doi.org/10.2134/ agronj2019.04.0280.

Barrowclough, M., Alwang, J., 2017. Farmer preferences for conservation agriculture attributes: a choice experiment from Ecuador. Environ. Dev. Sustain. 20, 2681-2705.

Barthès, B., Barthès, B., Azontonde, A., Blanchart, E., Girardin, C., Villenave, C., Lesaint, S., Oliver, R., Feller, C., 2004. Effect of a legume cover crop (Mucuna pruriens var. utilis) on soil carbon in an Ultisol under maize cultivation in southern Benin. Soil Use Manage. 20, 231-239.

Bergtold, J.S., Ramsey, S., Maddy, L., Williams, J.R., 2017. A review of economic considerations for cover crops as a conservation practice. Renewable Agric. Food Syst. 34, $1-15$.

Bilbro, J.D., 1991. Cover crops for wind erosion control in semiarid regions. In: Hargrove, W.L. (Ed.), Cover Crops for Clean Water. Soil and Water Conservation Society, Ankeny, IA, pp. 36-38.

Black, A.L., Tanaka, D.L., 1997. A conservation tillage-cropping systems study in the northern Great Plains of the United States. In: Paul, E.A., Paustian, K.H., Elliott, E.T., Cole, C.V. (Eds.), Soil Organic Matter in Temperate Agroecosystems: Long-Term Experiments in North America. CRC Press, Boca Raton, FL, pp. 335-342.

Bowen, W.T., Jones, J.W., Carsky, R.J., Quintana, J.O., 1993. Evaluation of the nitrogen submodel of CERES-Maize following legume green manure incorporation. Agron. J. 85, 153-159.

Boydston, R., Hang, A., 1995. Rapeseed (Brassica napus) green manure crop suppresses weeds in potato (Solanum tuberosum). Weed Technol. 9, 669-675.

Buckles, D., 1995. Velvetbean: a "new" plant with a history. Econ. Bot. 49, 13-25.

Bucks, D.A., Sammis, T.W., Dickey, G.L., 1990. Irrigation for arid areas. In: Hoffman, G.J., Howell, T.A., Solomon, K.H. (Eds.), Management of Farm Irrigation Systems. American Society of Agricultural Engineers, Saint Joseph, pp. 499-548.

Chela, E., 2008. Evaluacion de la perdida del suelo por erosion hidrica en tres sistemas de produccion en la microcuenca de la quebrada chilcapamba cantón Chillanes, provincia de Bolivar. (In Spanish.) Thesis, Bolívar State University (Universidad Estatal de Bolívar), Guaranda, Ecuador.

Chibarabada, T., Modi, A., Mabhaudhi, T., 2017. Expounding the value of grain legumes in the semi- and arid tropics. Sustainability 9, 60. https://doi.org/10.3390/su9010060.

Chikowo, R., Corbeels, M., Mapfumo, P., Tittonell, P., Vanlauwe, B., Giller, K.E., 2010. Nitrogen and phosphorus capture and recovery efficiencies, and crop responses to a range of soil fertility management strategies in sub-Saharan Africa. Nutr. Cycl. Agroecosyst. 88, $59-77$. 
Chikoye, D., Udensi, U.E., Ogunyemi, S., 2005. Integrated management of cogongrass [Imperata cylindrica (L.) Rauesch.] in corn using tillage, glyphosate, row spacing, cultivar, and cover cropping. Agron. J. 97, 1164-1171.

Clark, A. (Ed.), 2007. Managing Cover Crops Profitably. Sustainable Agriculture Research and Education Program, Beltsville, MD.

Clark, A.J., Decker, A.M., Meisinger, J.J., McIntosh, M.S., 1997a. Kill date of vetch, rye, and vetch-rye mixture: I. Cover crop and corn nitrogen. Agron. J. 89, 427-434.

Clark, A.J., Decker, A.M., Meisinger, J.J., McIntosh, M.S., 1997b. Kill date of vetch, rye, and vetch-rye mixture: II. Soil moisture and corn yield. Agron. J. 89, 434-441.

Clark, A.J., Meisinger, J.J., Decker, A.M., Mulford, F.R., 2007a. Effects of a grass-selective herbicide in a vetch-rye cover crop system on nitrogen management. Agron. J. 99 (1), 36-42.

Clark, A.J., Meisinger, J.J., Decker, A.M., Mulford, F.R., 2007b. Effects of a grass-selective herbicide in a vetch-rye cover crop system on corn grain yield and soil moisture. Agron. J. 99 (1), 43-48.

Colla, G., Mitchell, J.P., Joyce, B.A., Huyck, L.M., Wallender, W.W., Temple, S.R., Hsiao, T.C., Poudel, D.D., 2000. Soil physical properties and tomato yield and quality in alternative cropping systems. Agron. J. 92, 924-932.

Collins, H.P., Delgado, J.A., Alva, A.K., Follett, R.F., 2007. Use of nitrogen-15 isotopic techniques to estimate nitrogen cycling from a mustard cover crop to potatoes. Agron. J. 99, 27-35.

Corlett, R.T., 2014. The impacts of climate change in the Tropics. In: State of the Tropics. vol. 2. James Cook University, Townsville, Australia, pp. 155-161.

Crews, T.E., Peoples, M.B., 2005. Can the synchrony of nitrogen supply and crop demand be improved in legume and fertilizer-based agroecosystems? A review. Nutr. Cycl. Agroecosyst. 72, 101-120.

Crusciol, C.A.C., Nascente, A.S., Borghi, E., Soratto, R.P., Martins, P.O., 2015. Improving soil fertility and crop yield in a tropical region with palisadegrass cover crops. Agron. J. 107, 2271-2280.

Dabney, S.M., Delgado, J.A., Reeves, D.W., 2001. Using winter cover crops to improve soil and water quality. Commun. Soil Sci. Plant Anal. 32, 1221-1250.

Dabney, S.M., Delgado, J.A., Meisinger, J.J., Schomberg, H.H., Liebig, M.A., Kaspar, T., Mitchell, J., Reeves, W., 2010. Using cover crops and cropping systems for nitrogen management. In: Delgado, J.A., Follett, R.F. (Eds.), Advances in Nitrogen Management for Water Quality. SWCS, Ankeny, IA, pp. 231-282.

De Bruin, J.L., Porter, P.M., Jordan, N.R., 2005. Use of a rye cover crop following corn in rotation with soybean in the upper Midwest. Agron. J. 97, 587-598.

Decker, A.M., Clark, A.J., Meisinger, J.J., Mulford, F.R., McIntosh, M.S., 1994. Legume cover crop contributions to no-tillage corn production. Agron. J. 86, 126-135.

Delgado, J.A., 1998. Sequential NLEAP simulations to examine effect of early and late planted winter cover crops on nitrogen dynamics. J. Soil Water Conserv. 53, 241-244.

Delgado, J.A., 2001. Use of simulations for evaluation of best management practices on irrigated cropping systems. In: Shaffer, M.J., Ma, L., Hansen, S. (Eds.), Modeling Carbon and Nitrogen Dynamics for Soil Management. Lewis Publishers, Boca Raton, FL, pp. 355-381.

Delgado, J.A., Follett, R.F., 2002. Carbon and nutrient cycles. J. Soil Water Conserv. 57, 455-464.

Delgado, J.A., Gantzer, C.J., 2015. The 4Rs for cover crops and other advances in cover crop management for environmental quality. J. Soil Water Conserv. 70, 142A-145A.

Delgado, J.A., Li, R., 2016. The Nanchang Communication about the potential for implementation of conservation practices for climate change mitigation and adaptation to achieve food security in the 21st century. Int. Soil Water Conserv. Res. 4, 148-150. 
Delgado, J.A., Sparks, R.T., Follett, R.F., Sharkoff, J.L., Riggenbach, R.R., 1999. Use of winter cover crops to conserve soil and water quality in the San Luis Valley of south central Colorado. In: Lal, R. (Ed.), Soil Quality and Soil Erosion. CRC Press, Boca Raton, FL, pp. 125-242.

Delgado, J.A., Riggenbach, R.R., Sparks, R.T., Dillon, M.A., Kawanabe, L.M., Ristau, R.J., 2001a. Evaluation of nitrate-nitrogen transport in potato-barley rotation. Soil Sci. Soc. Am. J. 65, 878-883.

Delgado, J.A., Ristau, R.J., Dillon, M.A., Duke, H.R., Stuebe, A., Follett, R.F., Shaffer, M.J., Riggenbach, R.R., Sparks, R.T., Thompson, A., Kawanabe, L.M., Kunugi, A., Thompson, K., 2001b. Use of innovative tools to increase nitrogen use efficiency and protect environmental quality in crop rotations. Commun. Soil Sci. Plant Anal. 32, 1321-1354.

Delgado, J.A., Dillon, M.A., Sparks, R.T., Follett, R.F., 2004. Tracing the fate of ${ }^{15} \mathrm{~N}$ in a small-grain potato rotation to improve accountability of nitrogen budgets. J. Soil Water Conserv. 59, 271-276.

Delgado, J.A., Shaffer, M., Hu, C., Lavado, R.S., Cueto Wong, J., Joosse, P., Li, X., RimskiKorsakov, H., Follett, R., Colon, W., Sotamayor, D., 2006. A decade of change in nutrient management: a new nitrogen index. J. Soil Water Conserv. 61, 62A-71A.

Delgado, J.A., Dillon, M.A., Sparks, R.T., Essah, S.Y.C., 2007a. A decade of advances in cover crops: cover crops with limited irrigation can increase yields, crop quality, and nutrient and water use efficiencies while protecting the environment. J. Soil Water Conserv. 62 (5), 110A-117A.

Delgado, J.A., Essah, S.Y.C., Dillon, M.A., Ingahn, R., Manter, D., Stuebe, A., Sparks, R.T., 2007b. Using green manures to enhance potato production: II, other benefits/effects on nutrient cycling, tuber yield and quality. In: Proc. 24th Annu. Potato/ Grain Conf. 30 Jan-2 Feb. 2007. Colorado State Univ., Monte Vista, CO, pp. 16-20.

Delgado, J.A., Shaffer, M.J., Lal, H., McKinney, S.P., Gross, C.M., Cover, H., 2008. Assessment of nitrogen losses to the environment with a Nitrogen Trading Tool (NTT). Comput. Electron. Agric. 63, 193-206.

Delgado, J.A., Del Grosso, S.J., Ogle, S.M., 2010a. ${ }^{15} \mathrm{~N}$ isotopic crop residue cycling studies suggest that IPCC methodologies to assess $\mathrm{N}_{2} \mathrm{O}-\mathrm{N}$ emissions should be reevaluated. Nutr. Cycl. Agroecosyst. 86, 383-390.

Delgado, J.A., Gross, C.M., Lal, H., Cover, H., Gagliardi, P., McKinney, S.P., Hesketh, E., Shaffer, M.J., 2010b. A new GIS Nitrogen Trading Tool concept for conservation and reduction of reactive nitrogen losses to the environment. Adv. Agron. 105, 117-171.

Delgado, J.A., Groffman, P.M., Nearing, M.A., Goddard, T., Reicosky, D., Lal, R., Kitchen, N.R., Rice, C.W., Towery, D., Salon, P., 2011. Conservation practices to mitigate and adapt to climate change. J. Soil Water Conserv. 66, 118A-129A. https:// doi.org/10.2489/jswc.66.4.118A.

Delgado, J.A., Nearing, M.A., Rice, C.W., 2013. Conservation practices for climate change adaptation. Adv. Agron. 121, 47-115.

Delgado, J., Barrera, V., Escudero, L., Cartagena, Y., Alwang, J., Stehouwer, R., Arévalo, J., D’Adamo, R., Domínguez, J., Valverde, F., Alvarado, S., 2019. Conservation agriculture increases profits in an Andean Region of South America. Agrosyst. Geosci. Environ. 2, 1-8. https://doi.org/10.2134/age2018.10.0050.

Delgado, J.A., Ascough II, J.C., Lighthart, N., Neer, D., 2020. Potential use of a new nitrogen trading tool to assess nitrogen management practices to protect groundwater quality. Comput. Electron. Agric. 159, 105195. https://doi.org/10.1016/j.compag. 2019.105195.

Dinesh, R., Suryanarayana, M.A., Ghoshal Chaudhuri, S., Sheeja, T.E., 2004. Long-term influence of leguminous cover crops on the biochemical properties of a sandy clay loam Fluventic Sulfaquent in a humid tropical region of India. Soil Tillage Res. 77, 69-77. 
Dinesh, R., Ghoshal Chaudhuri, S., Sheeja, T.E., Shiva, K.N., 2009. Soil microbial activity and biomass is stimulated by leguminous cover crops. J. Plant Nutr. Soil Sci. 172, 288-296.

Doran, J.W., Smith, M.S., 1991. Role of cover crops in nitrogen cycling. In: Hargrove, W.L. (Ed.), Cover Crops for Clean Water. Soil and Water Conservation Society, Ankeny, IA, pp. 85-90.

Dourojeanni, A., Jouravlev, A., 2001. Crisis de gobernabilidad en la gestión del agua: Desafios que enfrenta la implementacion de las recomendaciones contenidas en el capitulo 18 del Programa 21 (In Spanish.). Economic Commission for Latin America and the Caribbean (Comision Economica para America Latina y el Caribe), Santiago, Chile.

Echeverría, M., 2002a. Financing watershed conservation: the FONAG water fund in Quito, Ecuador. In: Pagiola, S., Bishop, J., Landell-Mills, N. (Eds.), Selling Forest Environmental Services: Market-based Mechanisms for Conservation and Development. Earthscan, London, United Kingdom, pp. 91-101.

Echeverría, M., 2002b. Water User Associations in the Cauca Valley, Colombia: A Voluntary Mechanism to Promote Upstream-Downstream Cooperation in the Protection of Rural Watersheds. Land-Water Linkages in Rural Watersheds Case Study Series. Food and Agriculture Organization of the United Nations, Rome, Italy.

Erenstein, O., 2003. Smallholder conservation farming in the tropics and sub-tropics: a guide to the development and dissemination of mulching with crop residues and cover crops. Agr Ecosyst Environ 100, 17-37.

Escudero, L., Delgado, J., Monar, C., Valverde, F., Barrera, V., Alwang, J., 2014. A new Nitrogen Index for assessment of nitrogen management of Andean mountain cropping systems of Ecuador. Soil Sci. 179, 130-140.

Essah, S.Y.C., Delgado, J.A., Dillon, M., Sparks, R., 2012. Cover crops can improve potato tuber yield and quality. HortTechnology 22, 185-190.

Evanylo, G.K., 1991. Rye nitrogen cycling for corn and potato production. In: Hargrove, W.L. (Ed.), Cover Crops for Clean Water. Soil and Water Conservation Society, Ankeny, IA, pp. 101-103.

Farahani, H.J., Peterson, G.A., Westfall, D.G., 1998. Dryland cropping intensification: a fundamental solution to efficient use of precipitation. Adv. Agron. 64, 197-223.

Fofana, B., Breman, H., Carsky, R.J., Van Reuler, H., Tamelokpo, A.F., Gnakpenou, K.D., 2004. Using mucuna and $\mathrm{P}$ fertilizer to increase maize grain yield and $\mathrm{N}$ fertilizer use efficiency in the coastal savanna of Togo. Nutr. Cycl. Agroecosyst. 68, 213-222.

Franzluebbers, A.J., Stuedemann, J.A., 2015. Does grazing of cover crops impact biologically active soil carbon and nitrogen fractions under inversion or no tillage management? J. Soil Water Conserv. 70, 365-373.

Frye, W.W., Smith, W.G., Williams, R.J., 1985. Economics of winter cover crops as a source of nitrogen for no-till corn. J. Soil Water Conserv. 40, 246-249.

Ganry, F., Feller, C., Harmand, J.-M., Guibert, H., 2001. Management of soil organic matter in semiarid Africa for annual cropping systems. Nutr. Cycl. Agroecosyst. 61, 105-118.

Grant, C.A., Peterson, G.A., Campbell, C.A., 2002. Nutrient considerations for diversified cropping systems in the Northern Great Plains. Agron. J. 94, 186-198.

Harden, C.P., 1993. Land Use, Soil erosion, and Reservoir Sedimentation in an Andean drainage basin in Ecuador. Mt. Res. Dev. 13 (2), 177-184.

Hartz, T.K., Johnstone, P.R., Miyao, E.M., Davis, R.M., 2005. Mustard cover crops are ineffective in suppressing soilborne disease or improving processing tomato yield. HortScience 40, 2016-2019.

Holderbaum, J.F., Decker, A.M., Meisinger, J.J., Mulford, F.R., Vough, L.R., 1990. Fallseeded legume cover crops for no-tillage corn in the humid east. Agron. J. 82, 117-124.

Hu, C., Delgado, J.A., Zhang, X., Ma, L., 2005. Assessment of groundwater use by wheat (Triticum aestivum L.) in the Luancheng Xian region and potential implications for water conservation in the northwestern North China plain. J. Soil Water Conserv. 60, 80-88. 
Ile, E., Hamadina, M.K., Zufa, K., Henrot, J., 1996. Note on effects of a Mucuna pruriens var. utilis crop on the growth of maize (Zea mays) on an acid ultisol in southeastern Nigeria. Field Crop Res. 48, 135-140.

Islam, N., Wallender, W.W., Mitchell, J., Wicks, S., Howitt, R.E., 2006. A comprehensive experimental study with mathematical modeling to investigate the affects of cropping practices on water balance variables. Agric Water Manag 82, 129-147.

Johnson, T.J., Kaspar, T.C., Kohler, K.A., Corak, S.J., Logsdon, S.D., 1998. Oat and rye overseeded into soybean as fall cover crops in the upper Midwest. J. Soil Water Conserv. 53, 276-279.

Joyce, B.A., Wallender, W.W., Mitchell, J.P., Huyck, L.M., Temple, S.R., Brolnstrom, P.N., Hsaio, T.C., 2002. Infiltration and soil water storage under winter cover cropping in California's Sacramento Valley. Trans. ASAE 42 (2), 315-326.

Kambauwa, G., Mlamba, J., Delgado, J.A., Kabambe, V., 2015. Conservation strategies to adapt to projected climate change impacts in Malawi. J. Soil Water Conserv. 70, 109A-114A.

Kaspar, T.C., Bakker, M.G., 2015. Biomass production of 12 winter cereal cover crop cultivars and their effect on subsequent no-till corn yield. J. Soil Water Conserv. 70, 353-364. https://doi.org/10.2489/jswc.70.6.353.

Kaspar, T.C., Radke, J.K., Laflen, J.M., 2001. Small grain cover crops and wheel traffic effects on infiltration, runoff, and erosion. J. Soil Water Conserv. 56, 160-164.

Kaspar, T.C., Jaynes, D.B., Parkin, T.B., Moorman, T.B., 2007. Rye cover crop and gamagrass strip effects on $\mathrm{NO}_{3}$ concentration and load in tile drainage. J. Environ. Qual. 36, 1503-1511.

Kessavalou, A., Walters, D.T., 1997. Winter rye as a cover crop following soybean under conservation tillage. Agron. J. 89, 68-74.

Kladivko, E.J., Kaspar, T.C., Jaynes, D.B., Malone, R.W., Singer, J., Morin, X.K., Searchinger, T., 2014. Cover crops in the upper midwestern United States: potential adoption and reduction of nitrate leaching in the Mississippi River Basin. J. Soil Water Conserv. 69, 279-291.

Komatsuzaki, M., Wagger, M.G., 2015. Nitrogen recovery by cover crops in relation to time of planting and growth termination. J. Soil Water Conserv. 70, 385-398. https://doi. org/10.2489/jswc.70.6.385.

Lal, R., 2002. Carbon sequestration in dryland ecosystems of West Asia and North Africa. Land Degrad. Dev. 13, 45-59.

Lal, R., 2015. Soil carbon sequestration and aggregation by cover cropping. J. Soil Water Conserv. 70, 329-339. https://doi.org/10.2489/jswc.70.6.329.

Lal, R., Wilson, G.F., Okigbo, B.N., 1978. No-till farming after various grasses and leguminous cover crops in tropical alfisol. I. Crop performance. Field Crop Res. 1, 71-84.

Lal, R., Regnier, E., Eckert, D.J., Edwards, W.M., Hammond, R., 1991. Expectations of cover crops for sustainable agriculture. In: Hargrove, W.L. (Ed.), Cover Crops for Clean Water. Soil and Water Conservation Society, Ankeny, IA, pp. 1-11.

Lal, R., Delgado, J.A., Groffman, P.M., Millar, N., Dell, C., Rotz, A., 2011. Management to mitigate and adapt to climate change. J. Soil Water Conserv. 66, 276-285.

Lal, R., Delgado, J.A., Gulliford, J., Nielsen, D., Rice, C.W., Van Pelt, R.S., 2012. Adapting agriculture to drought and extreme events. J. Soil Water Conserv. 67, 162A-166A.

Langdale, G.W., Blevins, R.L., Karlen, D.L., McCool, D.K., Nearing, M.A., Skidmore, E.L., Thomas, A.W., Tyler, D.D., Williams, J.R., 1991. Cover crop effects on soil erosion by wind and water. In: Hargrove, W.L. (Ed.), Cover Crops for Clean Water. Soil and Water Conservation Society, Ankeny, IA, pp. 15-21.

Lehmann, J., Pereira da Silva Jr., J., Schroth, G., Gebauer, G., Ferreira da Silva, L., 2000. Nitrogen use in mixed tree crop plantations with a legume cover crop. Plant and Soil 225, 63-72. 
Li, L., Malone, R.W., Ma, L., Kaspar, T.C., Jaynes, D.B., Saseendran, S.A., Thorp, K.R., Yu, Q., Ahuja, L.R., 2008. Winter cover crop effects on nitrate leaching in subsurface drainage as simulated by RZWQM-DSSAT. Trans. ASABE 51, 1575-1583.

Liebl, R., Simmons, F.W., Wax, L.M., Stoller, E.W., 1992. Effect of rye (Secale cereale) mulch on weed control and soil moisture in soybean (Glycine max). Weed Technol. 6, 838-846.

Lobell, D.B., Bänziger, M., Magorokosho, C., Vivek, B., 2011. Nonlinear heat effects on African maize as evidenced by historical yield trials. Nat. Clim. Chang. 1, 42-45. http://www.nature.com/nclimate/journal/v1/n1/full/nclimate1043.html.

Luna-Orea, P., Wagger, M.G., Gumpertz, M.L., 1996. Decomposition and nutrient release dynamics of two tropical legume cover crops. Agron. J. 88, 758-764.

Lyon, D.J., Monz, C.A., Brown, R.E., Metherell, A.K., 1996. Soil organic matter changes over two decades of winter wheat fallow cropping in western Nebraska. In: Paul, E.A., Paustian, K.A., Elliot, E.T., Cole, C.V. (Eds.), Soil Organic Matter in Temperate Agroecosystems. Lewis Publishers, Boca Raton, FL, pp. 343-351.

Malone, R.W., Huth, N., Carberry, P.S., Ma, L., Kaspar, T.C., Karlen, D.L., Meade, T., Kanwar, R.S., Heilman, P., 2007. Evaluating and predicting agricultural management effects under tile drainage using modified APSIM. Geoderma 140, 310-322.

Marcillo, G.S., Miguez, F.E., 2017. Corn yield response to winter cover crops: an updated meta-analysis. J. Soil Water Conserv. 72, 226-239.

Marston, L., Konar, M., Cai, X., Troy, T.J., 2015. Virtual groundwater transfers from overexploited aquifers in the United States. Proc. Natl. Acad. Sci. U. S. A. 112, 8561-8566. http://www.pnas.org/lookup/suppl/doi:10.1073/pnas.1800442115/-/DCSupplemental.

Martínez-Mera, E., Valencia, E., Cuevas, H., 2016. Yield evaluation of sweet corn (Zea mays L. 'Suresweet') with cover crops dwarf velvet bean (Mucuna pruriens) and crotalaria (Crotalaría júncea 'Tropic Sun') on an Oxisol of Puerto Rico. J. Agric. Univ. P. R. 100 (1), 57-70.

Mauch, K.J., Delgado, J.A., Bausch, W.C., Barbarick, K., McMaster, G., 2008. New weighing method to measure shoot water interception. J. Irrig. Drain. Eng. 134 (3), $349-355$.

Meisinger, J.J., Delgado, J.A., 2002. Principles for managing nitrogen leaching. J. Soil Water Conserv. 57, 485-498.

Meisinger, J.J., Hargrove, W.L., Mikkelsen, R.B., Williams, J.R., Benson, V.W., 1991. Effect of cover crops on groundwater quality. In: Hargrove, W.L. (Ed.), Cover Crops for Clean Water. Proc. Int. Conf. 9-11 April 1991. Jackson, TN. Soil Water Conserv. Soc. Am, Ankeny, IA, pp. 57-68.

Merrill, S.D., Krupinsky, J.M., Tanaka, D.L., Anderson, R.L., 2006. Soil coverage by residue as affected by ten crop species under no-till in the northern Great Plains. J. Soil Water Conserv. 61, 7-13.

Mitchell, J.P., Peters, D.W., Shenan, C., 1999. Changes in soil water storage in winter fallowed and cover crop soils. J. Sustain. Agric. 15 (2/3), 19-31.

Mitchell, J.P., Shrestha, A., Irmak, S., 2015. Trade-offs between winter cover crop production and soil water depletion in the San Joaquin Valley, California. J. Soil Water Conserv. 70, 430-440. https://doi.org/10.2489/jswc.70.6.430.

Monar, C., Saavedra, A., Escudero, L., Delgado, J., Alwang, J., Barrera, V., Botello, R., 2013. Positive impacts in soil and water conservation in an Andean region of South America: case scenarios from a US Agency for International Development multidisciplinary cooperative project. J. Soil Water Conserv. 68, 25-30.

Montgomery, D.R., 2007. Soil erosion and agricultural sustainability. Proc. Natl. Acad. Sci. U. S. A. 104, 13268-13272.

Mutchler, C.K., McDowell, L.L., 1990. Soil loss from cotton with winter cover crops. Trans. ASAE 33, 432-436. 
Pandey, C.B., Begum, M., 2010. The effect of a perennial cover crop on net soil $\mathrm{N}$ mineralization and microbial biomass carbon in coconut plantations in the humid tropics. Soil Use Manage. 26, 158-166.

Perin, A., Silva Santos, R.H., Urquiaga, S.S., Cecon, P.R., Marinho Guerra, J.G., de Freitas, G.B., 2006. Sunnhemp and millet as green manure for tropical maize production. Sci. Agric. 63 (5), 453-459.

Peterson, G.A., Schlegel, A.J., Tanaka, D.L., Jones, O.R., 1996. Precipitation use efficiency as impacted by cropping and tillage systems. J. Prod. Agric. 9, 180-186.

Peterson, G.A., Halvorson, A.D., Havlin, J.L., Jones, O.R., Lyone, D.J., Tanaka, D.L., 1998. Reduced tillage and increasing cropping intensity in the Great Plains conserves soil C. Soil Tillage Res. 47, 207-218.

Pink, L.A., Allison, F.E., Gaddy, U.L., 1945. Greenhouse experiments on the effect of green manures upon $\mathrm{N}$ recovery and soil carbon content. Soil Sci. Soc. Am. Proc. 10, 230-239.

Pink, L.A., Allison, F.E., Gaddy, U.L., 1948. Greenhouse experiments on the effect of green manures crops of varying carbon-nitrogen ratios upon nitrogen availability and soil organic matter content. Agron. J. 40, 237-248.

Pruski, F.F., Nearing, M.A., 2002. Runoff and soil loss responses to changes in precipitation: a computer simulation study. J. Soil Water Conserv. 57 (1), 7-16.

Quemada, M., Cabrera, M.L., 1995a. Carbon and nitrogen mineralized from leaves and stems of four cover crops. Soil Sci. Soc. Am. J. 59, 471-477.

Quemada, M., Cabrera, M.L., 1995b. CERES-N model predictions of nitrogen mineralized from cover crops residues. Soil Sci. Soc. Am. J. 59, 1059-1065.

Quintero, M., Comerford, N.B., 2013. Effects of conservation tillage on total and aggregated soil organic carbon in the Andes. Open J. Soil Sci. 3, 361-373.

Rangely, W.R., 1987. Irrigation and drainage in the world. In: Jordan, W.R. (Ed.), Proceedings of Water and Water Policy in World Food Supplies, Conference Held in College Station, Texas. Agriculture and Mining University Press, College Station, TX, pp. 29-35.

Rasse, D.P., Ritchie, J.T., Peterson, W.R., Wei, J., Smucker, A.J.M., 2000. Rye cover crop and nitrogen fertilization effects on nitrate leaching in inbred maize fields. J. Environ. Qual. 29, 298-304.

Ray, D.K., West, P.C., Clark, M., Gerber, J.S., Prishchepov, A.V., Chatterjee, S., 2019. Climate change has likely already affected global food production. PLoS One 14 (5), e0217148. https://doi.org/10.1371/journal.pone.0217148.

Reeder, R., Westermann, D., 2006. Soil management practices. In: Schnepf, M., Cox, C. (Eds.), Environmental Benefits of Conservation on Cropland: The Status of our Knowledge. Soil and Water Conservation Society, Ankeny, IA, pp. 1-88.

Reeves, D.W., 1994. Cover crops and rotations. In: Hatfield, J.L., Stewart, B.A. (Eds.), Crops Residue Management. Advances in Soil Science, Lewis Publishers, CRC Press, Boca Raton, FL, pp. 125-172.

Ruffo, M.L., Bullock, D.G., Bollero, G.A., 2004. Soybean yield as affected by biomass and nitrogen uptake of cereal rye in winter cover crop rotations. Agron. J. 96, 800-805.

Russelle, M.P., Hargrove, W.L., 1989. Cropping systems: ecology and management. In: Follett, R.F. (Ed.), Nitrogen Management and Groundwater Protection. Elsevier Sci. Publ. Co., New York, pp. 277-317.

Sainju, U.M., Singh, B.P., Whitehead, W.F., 2002. Long-term effects of tillage, cover crops, and nitrogen fertilization on organic carbon and nitrogen concentrations in sandy loam soils in Georgia, USA. Soil Tillage Res. 63, 167-179.

Sainju, U.M., Singh, H.P., Singh, B.P., 2015. Cover crop effects on soil carbon and nitrogen under bioenergy sorghum crops. J. Soil Water Conserv. 70, 410-417. 
Sanginga, N., Mulongoy, K., Swift, M.J., 1992. Contribution of soil organisms to the sustainability and productivity cropping systems in the tropics. Agric. Ecosyst. Environ. 41, 135-152.

Sarrantonio, M., 2007. Building soil fertility and tilth with cover crops. In: Clark, A. (Ed.), Managing Cover Crops Profitably, third ed. Sustainable Agriculture Research and Education, Beltsville, MD, pp. 16-24.

Sarto, M.V.M., Borges, W.L.B., Sarto, J.R.W., Pires, C.A.B., Rice, C.W., Rosolem, C.A., 2020. Soil microbial community and activity in a tropical integrated crop-livestock system. Appl. Soil Ecol. 145, 103350.

Scheelbeek, P.F.D., Bird, F.A., Tuomisto, H.L., Green, R., Harris, F.B., Joy, E.J.M., Chalabi, Z., Allen, E., Haines, A., Dangour, A.D., 2018. Effect of environmental changes on vegetable and legume yields and nutritional quality. Proc. Natl. Acad. Sci. U. S. A. 115, 6804-6809. http://www.pnas.org/lookup/suppl/doi:10.1073/pnas. 1800442115/-/DCSupplemental.

Schroth, G., Lehmann, J., Rodrigues, M.R.L., Barros, E., Macêdo, J.L.V., 2001. Plant-soil interactions in multistrata agroforestry in the humid tropics. Agr. Syst. 53, 85-102.

Seo, J.-H., Meisinger, J.J., Lee, H.-J., 2006. Recovery of nitrogen-15-labeled hairy vetch and fertilizer applied to corn. Agron. J. 98, 245-254.

Shipley, P.R., Meisinger, J.J., Decker, A.M., 1992. Conserving residual corn fertilizer nitrogen with winter cover crops. Agron. J. 84, 869-876.

Six, J., Frey, S.D., Thiet, R.K., Batten, K.M., 2006. Bacterial and fungal contributions to carbon sequestration in agroecosystems. Soil Sci. Soc. Am. J. 70, 555-569.

Snapp, S.S., Swinton, S.M., Labarta, R., Mutch, D., Black, J.R., Leep, R., Nyiraneza, J., O'Neil, K., 2005. Evaluating cover crops for benefits and costs and performance within cropping system niches. Agron. J. 97, 322-332.

Sotomayor-Ramirez, D., Huckaba, R., Barnes, R., Dorcinvil, R., Espinosa, J., 2012. Inbred maize response to cover crops and fertilizer-nitrogen. J. Agric. Univ. P. R. 96, 37-55.

Spiegal, S., Bestelmeyer, B.T., Archer, D.W., Augustine, D.J., Boughton, E.H., Boughton, R.K., Cavigelli, M.A., Clark, P.E., Derner, J.D., Duncan, E.W., Hapeman, C.J., Harmel, R.D., Heilman, P., Holly, M.A., Huggins, D.R., King, K., Kleinman, P.J.A., Liebig, M.A., Locke, M.A., McCarty, G.W., Millar, N., Mirsky, S.B., Moorman, T.B., Pierson, F.B., Rigby, J.R., Robertson, G.P., Steiner, J.L., Strickland, T.C., Swain, H.M., Wienhold, B.J., Wulfhorst, J.D., Yost, M.A., Walthall, C.L., 2018. Evaluating strategies for sustainable intensification of US agriculture through the Long-Term Agroecosystem Research network. Environ. Res. Lett. 13, 034031.

Sriyani, N., Suprapto, H., Susanto, H., Lubis, A.T., Oki, Y., 2000. The development of sustainable biological production technologies harmonized with regional environmental conditions in East Asia. In: Final Report of the Grant-in-Aid for Creative Basic Research from Ministry of Education, Culture, and Sport of Japan 1994-1997.

Stanton, T.L., 1994. Nitrate Poisoning in Livestock. Service in Action No. 1.610. Colorado State Univ., Cooperative Ext. Fort Collins, CO 80523.

State of the Tropics, 2017. Sustainable Infrastructure for the Tropics. James Cook University, Townsville, Australia.

Strock, J.S., Porter, P.M., Russelle, M.P., 2004. Cover cropping to reduce nitrate loss through subsurface drainage in the northern U.S. Corn Belt. J. Environ. Qual. 33, 1010-1016.

SWCS, 2003. Conservation implications of climate change: soil erosion and runoff from cropland. In: A Report from the Soil and Water Conservation Society. Soil and Water Conservation Society, Ankeny, IA. 
SWCS, 2007. Planning for Extremes. A Report from a Soil and Water Conservation Society Workshop Held in Milwaukee, Wisconsin, November 1-3, 2006. Soil and Water Conservation Society, Ankeny, IA.

Thorup-Kristensen, K., 2001. Are differences in root growth of nitrogen catch crops important for their ability to reduce soil nitrate- $\mathrm{N}$ content, and how can this be measured? Plant and Soil 230, 185-195.

Thorup-Kristensen, K., Rasmussen, C.R., 2015. Identifying new deep-rooted plant species suitable as undersown nitrogen catch crops. J. Soil Water Conserv. 70, 399-409. https:// doi.org/10.2489/jswc.70.6.399.

Thorup-Kristensen, K., Magid, J., Jensen, L.S., 2003. Catch crops and green manures as biological tools in nitrogen management in temperate zones. Adv. Agron. 79, 227-302.

Tian, G., Kolawole, G.O., Salako, F.K., Kang, B.T., 1999. An improved cover crop-fallow system for sustainable management of low activity clay soils of the tropics. Soil Sci. 164 (9), 671-682.

Tigchelaar, M., Battisti, D.S., Naylor, R.L., Ray, D.K., 2018. Future warming increases probability of globally synchronized maize production shocks. Proc. Natl. Acad. Sci. U. S. A. 115, 6644-6649. http://www.pnas.org/lookup/suppl/doi:10.1073/pnas. 1718031115/-/DCSupplemental.

Tirado-Corbalá, R., López-Ramos, L., Valencia-Chin, E., Román-Paoli, E., 2018. Yield, decomposition, mineralization and nitrification of annual legumes in an oxisol. Agronomy 8, 244. https://doi.org/10.3390/agronomy8110244.

Traill, S., Bell, L.W., Dalgliesh, N.P., Wilson, A., Ramony, L.-M., Guppy, C., 2018. Tropical forage legumes provide large nitrogen benefits to maize except when fodder is removed. Crop Pasture Sci. 69, 183-193.

Trewin, B., 2014. The climates of the tropics, and how they are changing. In: State of the Tropics. vol. 1. James Cook University, Townsville, Australia, pp. 39-52.

Tribe, D., 1994. Feeding and Greening the World, the Role of Agricultural Research. Commonwealth Agriculture Bureau, Wallingford, UK.

Tucker, J.M., Cordy, D.R., Berry, L.J., Harvey, W.A., Fuller, T.C., 1961. Nitrate poisoning in livestock. In: California Agric. Exp. Stn. Cir. 506. University of California.

Unger, P.W., Vigil, M.F., 1998. Cover crop effects on soil water relationships. J. Soil Water Conserv. 53, 200-207.

United Nations, 2018. Statement by the Secretary-General on the IPCC Special Report Global Warming of $1.5^{\circ} \mathrm{C}$. October 8, 2018. https://www.un.org/sg/en/content/sg/ statement/2018-10-08/statement-secretary-general-ipcc-special-report-globalwarming-15-\%C2\%Bac.

van Dijk, A.I.J.M., 2002. Water and sediment dynamics in bench-terraced agricultural steeplands in West Java, Indonesia. Ph.D. Thesis, Free University, Amsterdam.

Vyn, T.J., Faber, J.G., Janovicek, K.J., Beauchamp, E.G., 2000. Cover crop effects on nitrogen availability to corn following wheat. Agron. J. 92, 915-924.

Wagger, M.G., 1989. Cover crop management and nitrogen rate in relation to growth and yield of no-tillage corn. Agron. J. 81, 533-538.

Wagger, M.G., Mengel, D.B., 1993. The role of nonleguminous cover crops in the efficient use of water and nitrogen. In: Hargrove, W.L. (Ed.), Cropping Strategies for Efficient Use of Water and Nitrogen. vol. 51. ASA Special Publication, Madison, WI, pp. 115-127.

Wagner-Riddle, C., Gillespie, T.J., Swanton, C.J., 1994. Rye cover crop management impact on soil water content, soil temperature and soybean growth. Can. J. Plant Sci. 74, 485-495.

Wallander, S., 2013. While Crop Rotations Are Common, Cover Crops Remain Rare. USDA, Economic Research Service, Washington, DC. http://www.ers.usda.gov/ 
amber-waves/2013-march/while-crop-rotations-are-common,-cover-crops-remainrare.aspx. VhFfDryLE64.

Walthall, C.L., Hatfield, J., Backlund, P., Lengnick, L., Marshall, E., Walsh, M., Adkins, S., Aillery, M., Ainsworth, E.A., Ammann, C., Anderson, C.J., Bartomeus, I., Baumgard, L.H., Booker, F., Bradley, B., Blumenthal, D.M., Bunce, J., Burkey, K., Dabney, S.M., Delgado, J.A., Dukes, J., Funk, A., Garrett, K., Glenn, M., Grantz, D.A., Goodrich, D., Hu, S., Izaurralde, R.C., Jones, R.A.C., Kim, S.H., Leaky, A.D.B., Lewers, K., Mader, T.L., McClung, A., Morgan, J., Muth, D.J., Nearing, M., Oosterhuis, D.M., Ort, D., Parmesan, C., Pettigrew, W.T., Polley, W., Rader, R., Rice, C., Rivington, M., Rosskopf, E., Salas, W.A., Sollenberger, L.E., Srygley, R., Stöckle, C., Takle, E.S., Timlin, D., White, J.W., Winfree, R., Morton, L.W., Ziska, L.H., 2012. Climate Change and Agriculture in the United States: Effects and Adaptation. USDA Technical Bulletin 1935. USDA, Washington, DC.

Wang, K., McSorley, R., Gallagher, R.N., 2003. Host status and amendment effects of cowpea on Meloidogyne incognita in vegetable cropping systems. Nematropica 33, 215-224.

Wang, K., McSorley, R., Gallagher, R.N., Kokalis-Burelle, N., 2008. Cover crops and organic mulches for nematode, weed and plant health management. Nematology 10 (2), 231-242.

Watts, N., Adger, W.N., Agnolucci, P., Blackstock, J., Byass, P., Cai, W., Chaytor, S., Colbourn, T., Collins, M., Cooper, A., Cox, P.M., Depledge, J., Drummond, P., Ekins, P., Galaz, V., Grace, D., Graham, H., Grubb, M., Haines, A., Hamilton, I., Hunter, A., Jiang, X., Li, M., Kelman, I., Liang, L., Lott, M., Lowe, R., Luo, Y., Mace, G., Maslin, M., Nilsson, M., Oreszczyn, T., Pye, S., Quinn, T., Svensdotter, M., Venevsky, S., Warner, K., Xu, B., Yang, J., Yin, Y., Yu, C., Zhang, Q., Gong, P., Montgomery, H., Costello, A., 2015. Health and climate change: policy responses to protect public health. Lancet 386, 1861-1914.

Wendt, R.C., Burwell, R.E., 1985. Runoff and soil losses for conventional, reduced, and no-tillage corn. J. Soil Water Conserv. 40, 450-454.

Westermann, D.T., Kleinkopf, G.E., Porter, L.K., 1988. Nitrogen fertilizer efficiencies on potatoes. Am. Potato J. 65, 377-386.

Westfall, D.G., Havlin, J.L., Hergert, G.W., Raun, W.R., 1996. Nitrogen management in dryland cropping systems. J. Prod. Agric. 9 (2), 192-199.

Williams, J.R., Kissel, D.E., 1991. Water percolation: an indicator of nitrogen-leaching potential. In: Follett, R.F., Power, J.F., Meisinger, J.J., Schepers, J.S., Smith, S.J. (Eds.), Managing Nitrogen for Groundwater Quality and Farm Profitability. Soil Science Society of America, Madison, WI, pp. 59-83.

WMO (World Meteorological Organization), 2019. The Global Climate in 2015-2019. World Meteorological Organization, Geneva, Switzerland.

Woodruff, N.P., Siddoway, F.H., 1965. A wind erosion equation. Soil Sci. Soc. Am. Proc. $29,602-608$.

Zhou, X., Chen, C., Lu, S., Rui, Y., Wu, H., Xu, Z., 2011. The short-term cover crops increase soil labile organic carbon in southeastern Australia. Biol. Fertil. Soils 48, 239-244.

Zhu, J.C., Gantzer, C.J., Anderson, S.H., Alberts, E.E., Beuselinck, R.R., 1989. Runoff, soil and dissolved nutrient losses from no-tillage soybean and winter cover crops. Soil Sci. Soc. Am. J. 53, 1210-1214. 